Juliano Borges de Freitas

\title{
FORMAÇÃO E GERÊNCIA DE REDES DE EMPRESAS: REQUISITOS PARA ADEQUAÇÃO DO PLANEJAMENTO E CONTROLE DA PRODUÇÃO - ESTUDO DE CASO EM OBRA DE CONSTRUÇÃO CIVIL DE GRANDE PORTE
}

\begin{abstract}
Dissertação apresentada à Escola de Engenharia de São Carlos da Universidade de São Paulo, como parte dos requisitos para a obtenção do Título de Mestre em Engenharia de Produção.
\end{abstract}

Orientador: Prof. Dr. Fábio Müller Guerrini 


\section{RESUMO}

FREITAS, J. B. (2005). Formação e gerência de redes de empresas: requisitos para a adequação do planejamento e controle da produção - estudo de caso em obra de construção civil de grande porte. Dissertação (Mestrado) - Escola de Engenharia de São Carlos, Universidade de São Paulo, São Carlos.

Uma Rede de Cooperação entre Empresas é definida como um grupo de empresas que interagem entre si pela troca de competências, de forma a atender uma série de suas necessidades que seriam de difícil satisfação no caso de atuarem isoladamente. Tendo em vista que o Planejamento e Controle da Produção possui importância de primeira grandeza dentro da empresa industrial como da rede de cooperação, e que, através da modelagem organizacional, pode-se observar as empresas com uma maior e melhor dimensão de entendimento, permitindo a integração dos seus componentes. Este trabalho tem o objetivo de adequar o PCP ao ambiente de redes de cooperação entre empresas, por meio da utilização da metodologia de modelagem organizacional (EKD) e de um Estudo de Caso em obra de construção civil.

Palavras-chaves: Rede de Cooperação entre Empresas; Processos de Negócios; Planejamento e Controle da Produção; Modelagem Organizacional. 


\begin{abstract}
FREITAS, J. B. (2005). Interorganizational networks development and management: requirement for production planning and control - case study in civil huge size construction. M.Sc. Dissertation - Escola de Engenharia de São Carlos, Universidade de São Paulo, São Carlos.
\end{abstract}

An interorganizational cooperation network is defined as a group of companies which interact among themselves for exchange of competences, so a series of necessity from the companies which would be a difficult satisfaction if the work were done individually. In view of that the Production Planning and Control has a great importance in an industrial company and also in the cooperation network. Through organizational modeling, can be observed the company with a greater and better dimension of agreement, which allows the integration of the companies' components. This work has the objective to adjust the PPC to the environment of cooperation networks between companies, once several resources, capacities and ability are congregated and must be endeavored by a flow of information, through the use of the methodology of organizational modeling (EKD) and Case Study in workmanship of civil construction.

Keywords: Interorganizational Networks; Cooperation; Business Process; Production Planning and Control; Organizational Modeling. 


\section{LISTA DE FIGURAS}

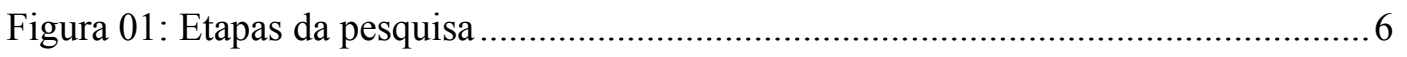

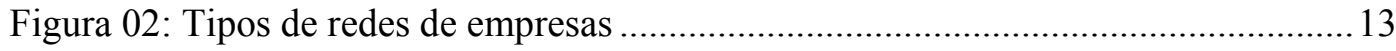

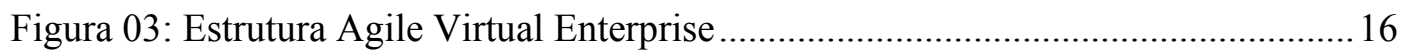

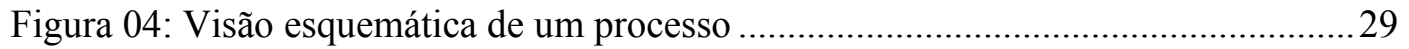

Figura 05: Framework de classificação de processos de negócio.....................................31

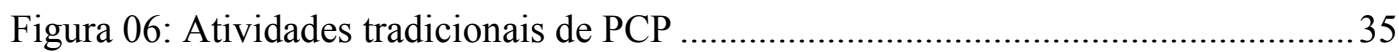

Figura 07: Conjunto de decisões tomadas em três hierarquias ..................................... 41

Figura 08 - O modelo de planejamento hierárquico da produção para sistemas

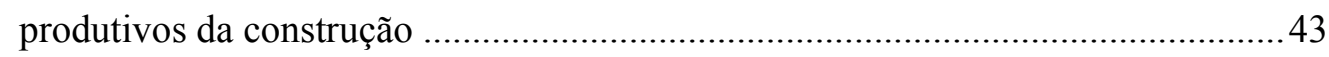

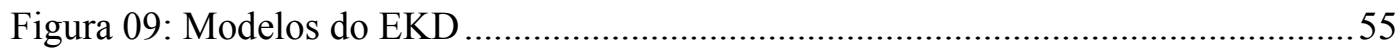

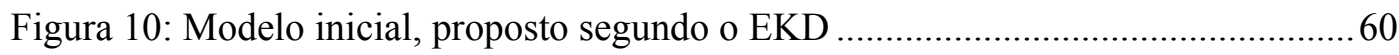

Figura 11: Etapas relevantes para elaboração de um Estudo de Caso. ............................63

Figura 12: Modelo de referência, proposto segundo o EKD. ........................................99

Figura 13: Representação do submodelo processo ................................................... 100

Figura 14: Representação do submodelo ator e recursos .......................................... 101

Figura 15: Representação do submodelo entidade/conceito e atributo .......................... 102

Figura 16: Representação do submodelo regra ......................................................... 103

Figura 17: Modelagem do Planejamento e Controle da Produção em Consórcio ......... 108

Figura 18: Modelo aplicado a fase Operacionalizando, referente a uma etapa do Lote1 


\section{LISTA DE TABELAS}

Tabela 01 - Elementos estruturais das redes de empresas. ......................................... 13

Tabela 02 - Processos típicos em empresas de fabricação. ............................................ 31

Tabela 03 - Processo de decisão no planejamento da produção......................................36

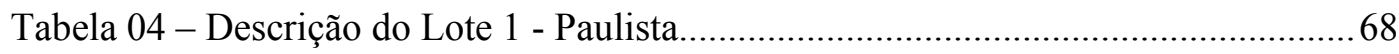

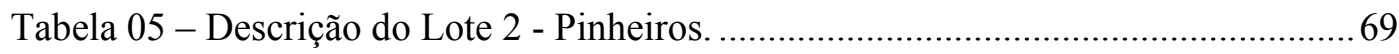

Tabela 06 - Descrição do Lote 6 - Pátio Vila Sônia. .................................................... 70

Tabela 07 - Experiência geral, período de tempo no negócio de construção.................. 73

Tabela 08 - Experiência geral, período de tempo no negócio de instalação de

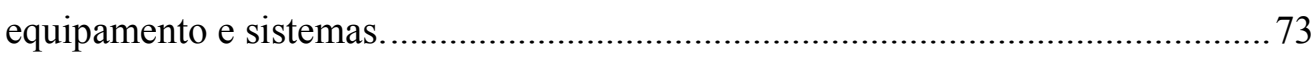

Tabela 09 - Experiência geral, movimentação média anual referente a trabalhos civis. 73

Tabela 10 - Experiência geral, movimentação média anual referente à instalação de

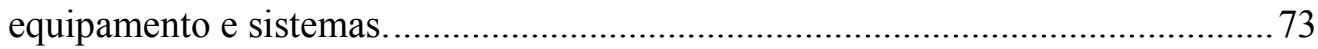

Tabela 11 - Experiência particular, trabalhos civis. ................................................. 74

Tabela 12 - Experiência particular, provisão e instalação de sistemas........................... 76

Tabela 13 - Experiência particular, projeto trabalhos civis e sistemas..........................77

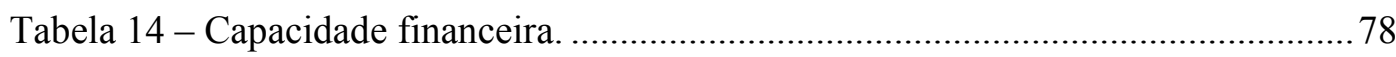

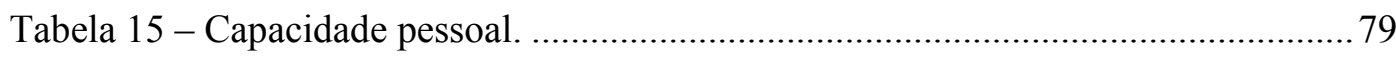

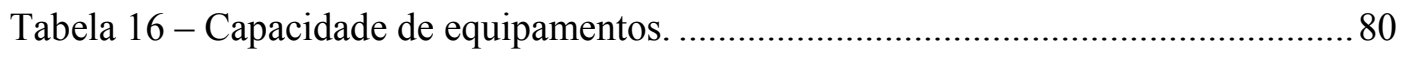




\section{LISTA DE ABREVIATURA E SIGLAS}

\begin{tabular}{|c|c|}
\hline AAMRC & Agile Aerospace Manufacturing Research Center \\
\hline APQC & American Productivity \& Quality Center \\
\hline AMEF & Agile Manufacturing Enterprise Forum \\
\hline ARIS & Architecture Integrated Information System \\
\hline ATO & Assemble to Order \\
\hline $\mathrm{CAD}$ & Computer Aided Design \\
\hline CAPS & Computer Architecture and Parallel Systems \\
\hline CEN & Comitê Europeu para Padronização \\
\hline CIMOSA & Computer Integrated Manufacturing Open System Architecture \\
\hline CO-IM & Cooperative Information Management \\
\hline COVE & Cooperation Infrastructure for Virtual Enterprises \\
\hline CRP & Planejamento das Capacidades Requeridas \\
\hline CYCLONE & Cyclic Operations Network System \\
\hline DRB & Comissão Examinadora de Disputas \\
\hline EDI & Eletronic Data Interchange \\
\hline E\&MTO & Enginering and Make to Order \\
\hline EKD & Enterprise Knowledge Development \\
\hline ENV & European Prestandard \\
\hline ESPRIT & The EU Information Technologies Programme \\
\hline ETO & Enginnering to Order \\
\hline $\mathrm{EV}$ & Empresa Virtual \\
\hline GAM & Modelo Genérico de Atividades \\
\hline ISO & International Standard Organization \\
\hline ISO TC 184 & $\begin{array}{l}\text { International Standard Organization Technical Committee TC } \\
184\end{array}$ \\
\hline JVA & Acordo de Joint Venture \\
\hline LOB & Linha de Balanço \\
\hline MRP & Material Requirement Planning \\
\hline MTS & Make to Stock \\
\hline MTO & Make to Order \\
\hline PCP & Planejamento e Controle da Produção \\
\hline PERA & Purdue Enterprise Reference Architecture \\
\hline
\end{tabular}




$\begin{array}{ll}\text { PERT } & \text { Program Evalution and Review Technique } \\ \text { PLENT } & \text { Planning Small-Medium Enterprise Network } \\ \text { PPC } & \text { Percentage of Planned Completed Activities } \\ \text { REDECOOP } & \text { Rede de cooperação e gestão do conhecimento } \\ \text { SC5 } & \text { Sub-Committee } 5 \\ \text { SFC } & \text { Shop Floor Control } \\ \text { SFPM } & \text { Shop Floor Production Model } \\ \text { VIVE } & \text { Virtual Vertical Enterprises } \\ \text { WG1 } & \text { Working Group } 1\end{array}$




\section{SUMÁRIO}

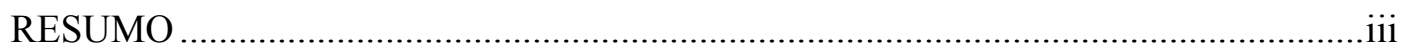

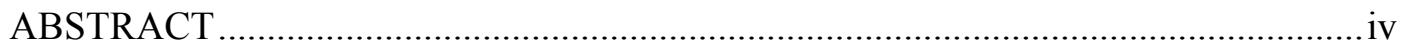

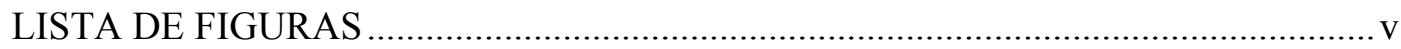

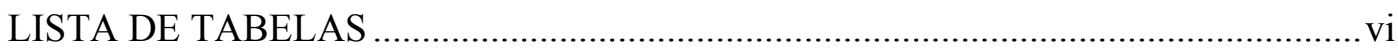

LISTA DE ABREVIATURA E SIGLAS .................................................................. vii

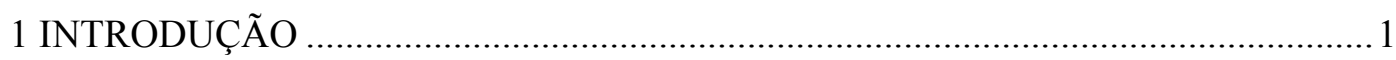

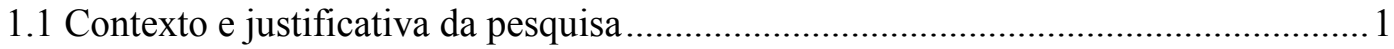

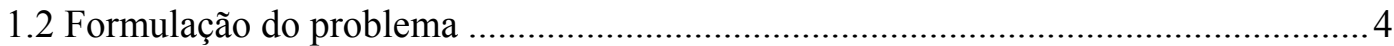

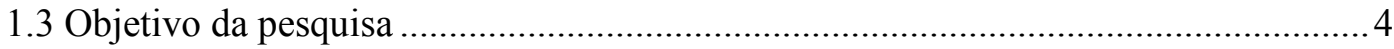

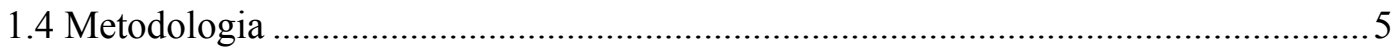

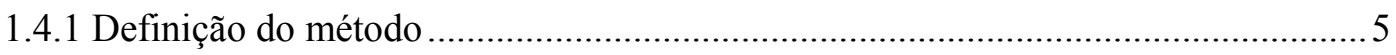

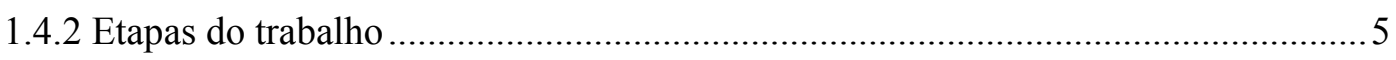

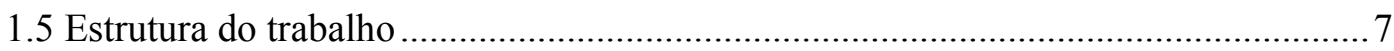

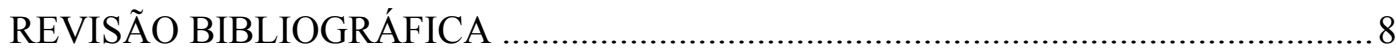

2 REDES DE COOPERAÇÃO ENTRE EMPRESAS: Morfologia, Ciclo de vida e

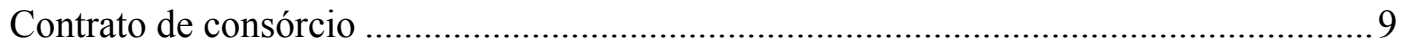

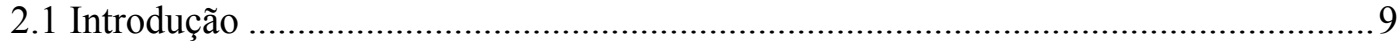

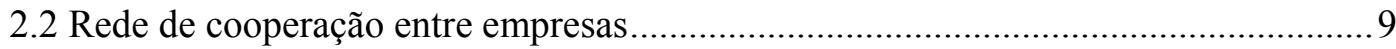

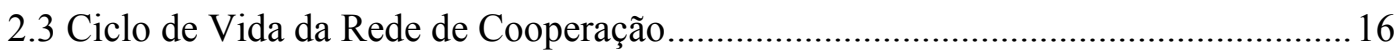

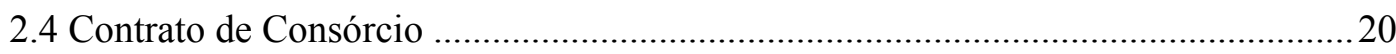

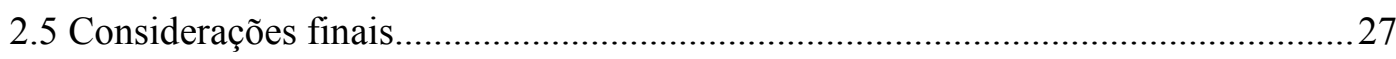

3 A IMPORTÂNCIA DO PROCESSO DE NEGÓCIO NO PLANEJAMENTO E CONTROLE DA PRODUÇÃO (PCP) DISTRIBUÍDA. ...........................................28

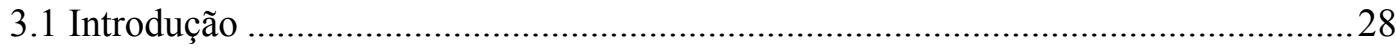

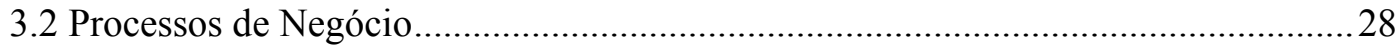

3.3 O Planejamento e Controle da Produção (PCP) na manufatura distribuída...............32

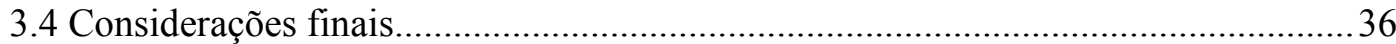

4 CARACTERIZAÇÃO DO SETOR DA CONSTRUÇÃO CIVIL E O SEU RESPECTIVO PROCESSO DE PLANEJAMENTO E CONTROLE DA PRODUÇÃO

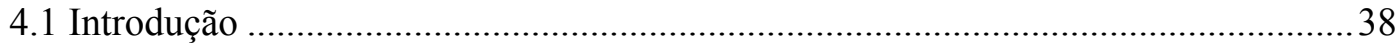

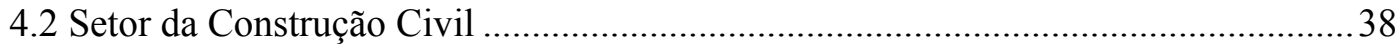

4.3 Planejamento e Controle da Produção e Construção Civil ..........................................40 


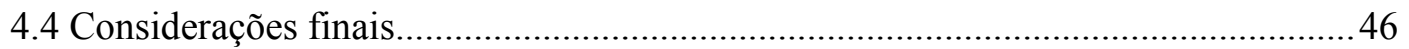

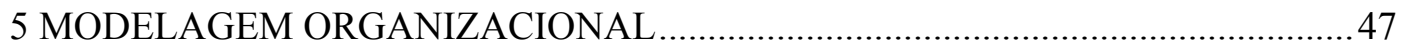

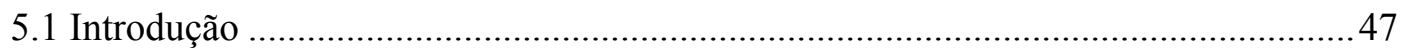

5.2 Modelagem Organizacional ou Modelagem de Empresas ...................................... 47

5.3 Arquitetura de referencia para modelagem e integração empresarial.......................49

5.3.1 ISO, framework de modelagem empresarial ......................................................50

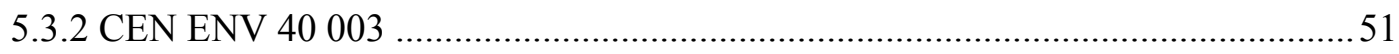

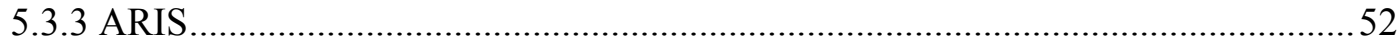

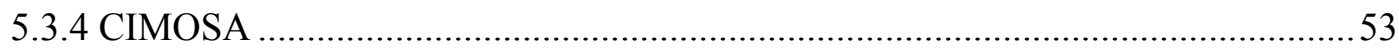

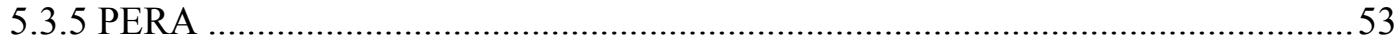

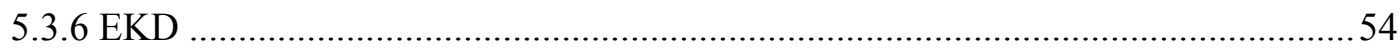

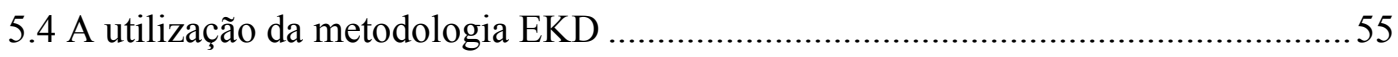

5.5 Considerações relevantes sobre a modelagem de obras de construção civil. ............56

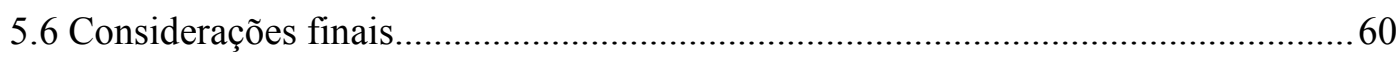

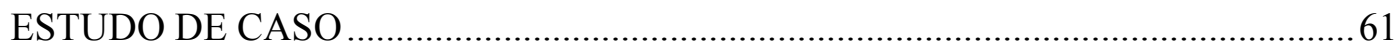

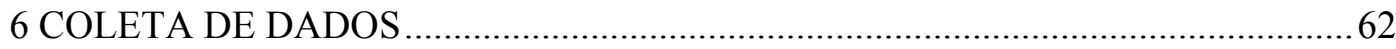

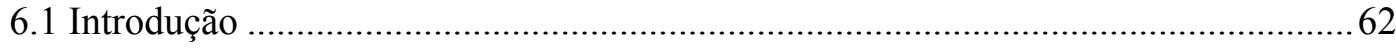

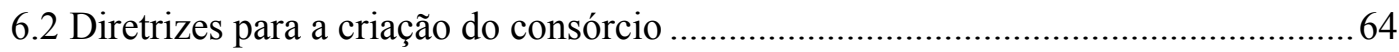

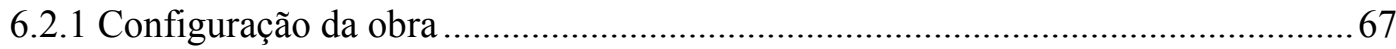

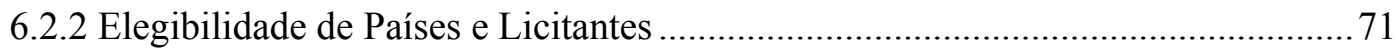

6.2.3 Critérios de qualificação baseados na capacidade e recursos ............................... 71

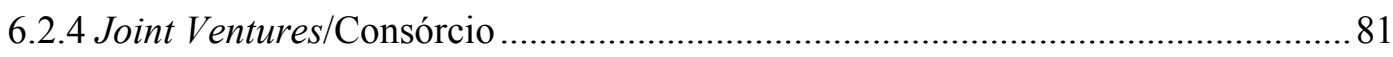

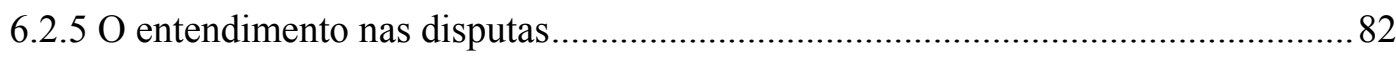

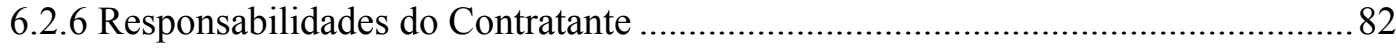

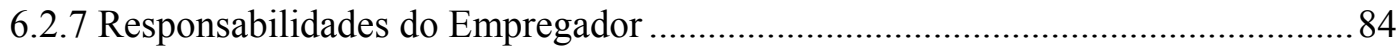

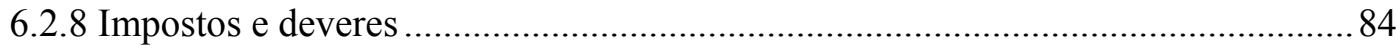

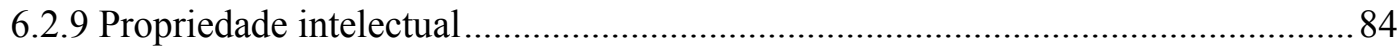

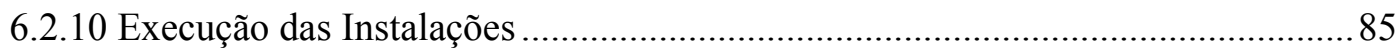

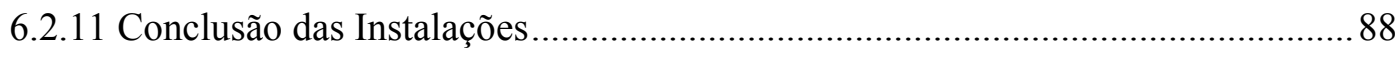

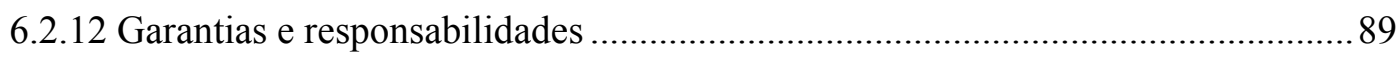

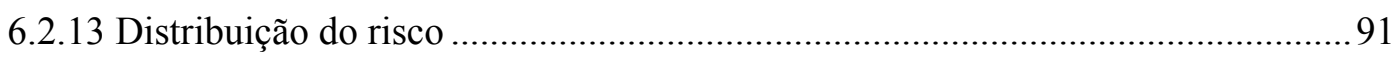

6.2.14 Mudança em elementos do Contrato.................................................................93

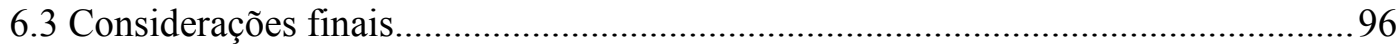

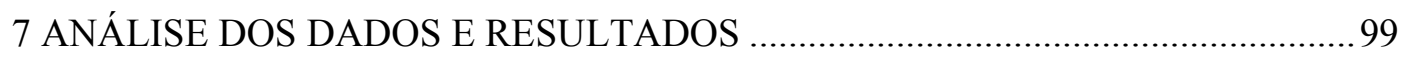




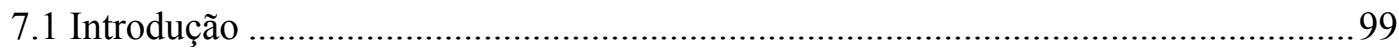

7.2 Análise e integração dos dados coletados e conceitos abordados............................99

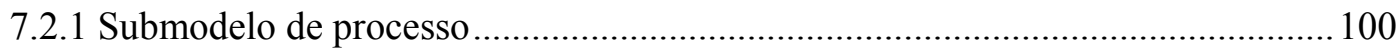

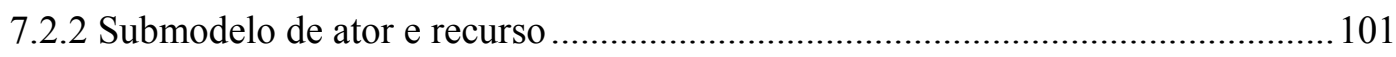

7.2.3 Submodelo de entidade e conceitos ou submodelo de objeto .............................. 101

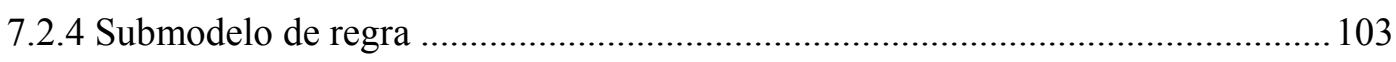

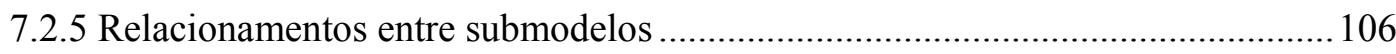

7.3 Apresentação da Modelagem do Planejamento e Controle da Produção................. 107

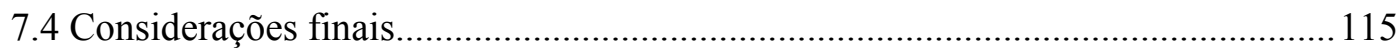

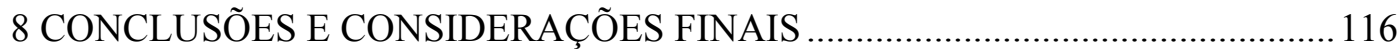

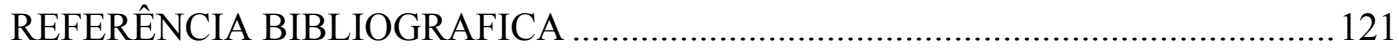

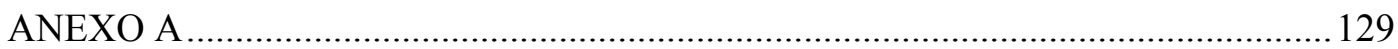




\section{INTRODUÇÃO}

Este capítulo apresenta o contexto no qual a pesquisa se insere, as justificativas que motivaram o seu desenvolvimento, assim como seu objetivo. Também são descritos o método de pesquisa, as etapas da pesquisa e a estrutura do trabalho.

\subsection{Contexto e justificativa da pesquisa}

As hierarquias tradicionais ainda estão sendo mantidas em muitas organizações ${ }^{1}$, mas abrandadas e transformadas em redes (PINE II, 1994).

Abandonando a estrutura por funções, que foi a forma organizacional predominante nas empresas do século XX, elas estão organizando seus recursos e fluxos ao longo de seus processos básicos de operação (GONÇALVES, 2000a). O mundo de Adam Smith e a sua forma de fazer negócios estão se tornando paradigmas do passado (HAMMER e CHAMPY, 1994).

Nesse sentido, as empresas enfrentam o desafio de reestruturar seus níveis hierárquicos em modelos mais enxutos e autônomos e necessitam da formação de cooperações para cobrir a sua deficiência em termos de recursos e conhecimento (BREMER e CORRÊA, 1997).

As organizações voltadas a processos produtivos estão sendo pressionadas a adotar novos conceitos diante da crescente competição global, da redução do ciclo de vida dos produtos e da customização em massa (WIENDAHL e HOBIS, 1998).

Existe o fato de que, para operar na nova economia global caracterizada pela onda de novos concorrentes que usam novas tecnologias e capacidades de redução de custos, as empresas estão implementando novas estratégias.

Dentre essas estratégias encontra-se a formação de redes ${ }^{2}$ entre empresas, uma prática que pretende garantir a sobrevivência e competitividade, principalmente, das

\footnotetext{
${ }^{1}$ A organização é entendida como uma rede de tomada de decisões. A eficácia dessa rede dependerá da articulação de diversos fatores estruturais e comportamentais (MOTTA, 1986). As organizações são estruturas para aprender e dirigir sistemas de fluxos e determinar os inter-relacionamentos das diferentes partes (MINTZBERG, 1995).

${ }^{2}$ As estruturas em rede constituem um quadro de referência que pode ser aplicável à investigação de múltiplos fenômenos caracterizados pela densidade de relacionamentos cooperativos entre os agentes, o
} 
pequenas e médias empresas (OLAVE e AMATO, 2001). Castells (1999) coloca a formação de redes entre empresas da seguinte forma: o modelo de redes multidirecionais posto em prática por empresas de pequeno e médio porte, e o modelo de licenciamento e subcontratação de produção sob controle de uma grande empresa.

Segundo Goulart (2000, p.2), atualmente as empresas têm optado por cooperações $^{3}$ e entres os fatos que impulsionam essa opção estão a concentração em competências essenciais e o desenvolvimento de tecnologias de informação. As empresas, visando tornarem-se mais competitivas, estão focando os seus negócios em suas competências essenciais, precisando cooperar para complementar as competências necessárias, a fim de oferecer produtos ou soluções para o mercado.

A busca por competitividade nas empresas direciona cada vez mais para uma estrutura orientada a processos de negócios (BREMER e LENZA, 2000). Ver a organização em termos de processos (alguns atravessando os limites externos da organização) implica, inevitavelmente, uma mudança interfuncional e interorganizacional (DAVENPORT, 1994).

Desta forma a centralização da empresa nos seus processos levará a desenhos organizacionais muito diferentes dos que conhecemos atualmente.

O primeiro estágio, não apenas previsível, mas que está sendo adotado em muitas empresas é o de redistribuição dos recursos humanos e técnicos das empresas ao longo dos processos de negócios As parcerias e as redes de empresas estão surgindo como um segundo estágio desse movimento de reforma conceitual, dessa forma, nem todos os recursos essenciais para a operação da empresa pertencem a ela (GONÇALVES, 1997, p.12).

Cooperação, flexibilidade, empreendedorismo e descentralização tornaram-se, desde então, os requisitos para a competitividade de empresas e indústrias (FARIA, 2000).

Existe uma clara tendência para que o processo de manufatura não seja executado por uma única empresa e, sim, que cada empresa é apenas um ponto que acrescenta um pouco de valor ao ciclo de produção inteiro. Porém, para tanto, existe o desafio de como o sistema de manufatura industrial será planejado e gerenciado, o que requer a definição de uma arquitetura de referência para cooperação e o

que reforça a interdependência entre suas respectivas competências e impõe a necessidade de algum tipo de coordenação coletiva das ações adotadas (Britto, 2002).

${ }^{3}$ Referindo-se à importância da cooperação, Pires et al. (2001) argumentam que para companhias que desejam cultivar e manter uma posição sustentável e lucrativa em mercados globais é essencial que associações ou empreendimentos cooperativos sejam montados e administrados efetivamente. Entretanto, não obstante o montante de esforços, recursos e interesses mobilizados por empresas, academia e outras instituições, ainda se questiona até que ponto as teorias de cooperação desenvolvidas pelos pesquisadores se aplicam à realidade (FARIA, 2000). Williams (2002), analisando redes interorganizacionais, avalia que o termo cooperação refere-se a relações estabelecidas e mantidas voluntariamente. 
desenvolvimento de uma plataforma de suporte flexível e apropriados protocolos e mecanismos. (CAMARINHA-MATOS e AFSARMANESH, 1999b)

Segundo Corrêa (1999), o processo de Planejamento e Controle da Produção (PCP), que em uma empresa já é fonte de várias dificuldades, passa a se tornar um grande desafio para o sucesso de uma rede de cooperação devido à complexidade de integração de recursos de diferentes empresas. Barbosa e Sacomano (2001) afirmam que em uma rede composta basicamente por empresas industriais, deve-se buscar estreita coordenação entre o planejamento da capacidade e o planejamento e controle da produção, onde a maior preocupação é o cumprimento de metas abrangentes e estratégicas por todas as empresas integrantes da rede.

Dessa forma, a adequação do PCP ao ambiente de redes de cooperação entre empresas mostra-se necessária, uma vez que diversos recursos, capacidades e competências são reunidos em uma rede e precisam ser diligenciados por um fluxo de informações adequado às suas necessidades. Segundo Amato (2000), as possibilidades de formação e/ou desenvolvimento de formas cooperativas de produção e das redes de cooperação produtiva entre empresas apresentam-se como uma tendência universal e irreversível.

Entre os grupos de pesquisa que se destacam no estudo de redes de cooperação podem-se destacar os seguintes:

- Esprit, (The EU information technologies (IT) programme): Funciona como um integrado programa industrial de $\mathrm{P} \& \mathrm{D}$, projeto e tecnologia. É administrado por DG III, o Diretório Geral para Indústria da Comissão européia (ESPRIT, 2003).

- CO-IM (Cooperative Information Management): Faz parte do Computer Architecture and Parallel Systems ( $\underline{\mathrm{CAPS}}$ ), vinculado à Universidade de Amsterdã, com pesquisas em administração de informação para desempenho multissistema, focando no desenho e desenvolvimento de arquiteturas e sistemas que suportam interoperabilidade e integração de sistemas de informação cooperativos (CO-IM, 2003).

- COVE (Cooperation Infrastructure for Virtual Enterprises): Aponta e avalia os resultados de pesquisas e práticas em empresas virtuais e negócios eletrônicos, conduzindo ao desenho de um modelo de referência comum, infra-estruturas de cooperação e prospectos para favorecer o desenvolvimento colaborativo (COVE, 2003). 
- VIVE (Virtual Vertical Enterprises): Sua proposta está baseada no conceito empresarial inovador do Integrador Empresarial, responsável por coordenar as atividades do Empreendimento Virtual ao longo de seu ciclo de vida e é constituído pelos seguintes elementos essenciais: Modelo Empresarial, InfraEstrutura de ICT, Proposta Legal e Melhores Práticas (VIVE, 2003).

Em âmbito nacional destaca-se o seguinte grupo de pesquisa :

- REDECOOP (Rede de cooperação e gestão do conhecimento): Investiga as alternativas de elevar o desempenho das empresas e seu poder de competitividade através dos arranjos interorganizacionais e das redes de cooperação produtiva, tais como clusters regionais, organizações/empresas virtuais, cooperativas, cadeias de suprimentos, etc. Além disso, objetiva-se identificar as oportunidades e as barreiras relativas à geração, difusão e gestão do conhecimento através das redes de cooperação interorganizacionais, dentro do contexto da globalização dos mercados e da reestruturação industrial com o advento do paradigma de produção enxuta/ágil/flexível. (REDECOOP, 2003)

\subsection{Formulação do problema}

A maior dificuldade na integração de empresas parceiras em uma rede de cooperação encontra-se no ajuste das capacidades dos parceiros e na definição comum de prazos. Assim, a integração dos processos e atividades do PCP entre as diferentes empresas é requisito fundamental para a formação de uma rede de cooperação.

O problema abordado nesta pesquisa está em definir quais são os processos de negócio, atividades e informações de interesse para o Planejamento e Controle da Produção em uma rede de cooperação assimétrica ${ }^{4}$.

\subsection{Objetivo da pesquisa}

Sistematizar o processo de planejamento e controle da produção no ambiente de redes assimétricas, utilizando um estudo de caso de caráter exploratório em uma obra de construção civil de grande porte, identificando os requisitos de interesse para o PCP.

\footnotetext{
${ }^{4}$ Segundo Grandori e Soda (1995), as redes de empresas podem ser divididas em assimétricas (quando existe um núcleo central de coordenação da rede, formado por uma ou grupo específico de empresa, ou seja, existe a presença de uma hierarquia de governança) e simétricas (baseadas na igualdade de poder: todos os participantes da rede compartilham a mesma capacidade de influência, ou seja, não existe uma hierarquia de governança).
} 


\subsection{Metodologia}

A seguir, são apresentados os aspectos metodológicos considerados para o desenvolvimento desta pesquisa, tendo em vista o objetivo proposto.

A metodologia é considerada como a maneira de conduzir a pesquisa, o conhecimento geral e habilidade que são necessários ao pesquisador para se orientar no processo de investigação, tomar decisões oportunas, selecionar conceitos, hipóteses, técnicas e dados adequados (THIOLLENT, 1983)

\subsubsection{Definição do método}

O método é o conjunto das atividades sistemáticas e racionais que, com maior segurança e economia, permite alcançar o objetivo e traçar o caminho a ser seguido, detectando erros e auxiliando nas decisões do cientista (LAKATOS e MARCONI, 1991).

Segundo Thiollent (1983), método é definido, em termos gerais, como procedimento utilizado para obter um resultado desejado.

A pesquisa será de um estudo de caso de caráter exploratório, procurando-se evitar a ocorrência de excesso de formalismo (teorização sem observação do real) e excesso de empirismo (observação sem teoria), conforme Thiollent (1983). A metodologia utilizada para a modelagem do processo "produzir" relacionado ao Planejamento e Controle da Produção será o Enterprise Knowledge Development (EKD).

\subsubsection{Etapas do trabalho}

A abordagem da metodologia soft, proposta por Pidd (1997), adaptado de Checkland (1981), apresenta os seguintes passos para a elaboração da pesquisa, fazendo um paralelo entre o mundo real e o pensamento sistêmico:

- Passo 1: A situação problemática não estruturada.

- Passo 2: A situação problemática expressa.

- Passo 3: Definições-chave de sistemas relevantes.

- Passo 4: Modelos conceituais.

- Passo 5: Comparação dos modelos conceituais com a situação problemática expressa.

- Passo 6: Mudanças possíveis desejadas.

- Passo 7: Ações para melhorar a situação problemática. 
Sendo o objetivo da pesquisa sistematizar os conceitos de planejamento e controle da produção no ambiente de redes de cooperação assimétricas, seguindo a abordagem da metodologia de sistemas desenvolvida por Checkland (1981), foram definidas as seguintes etapas representadas na figura 01:

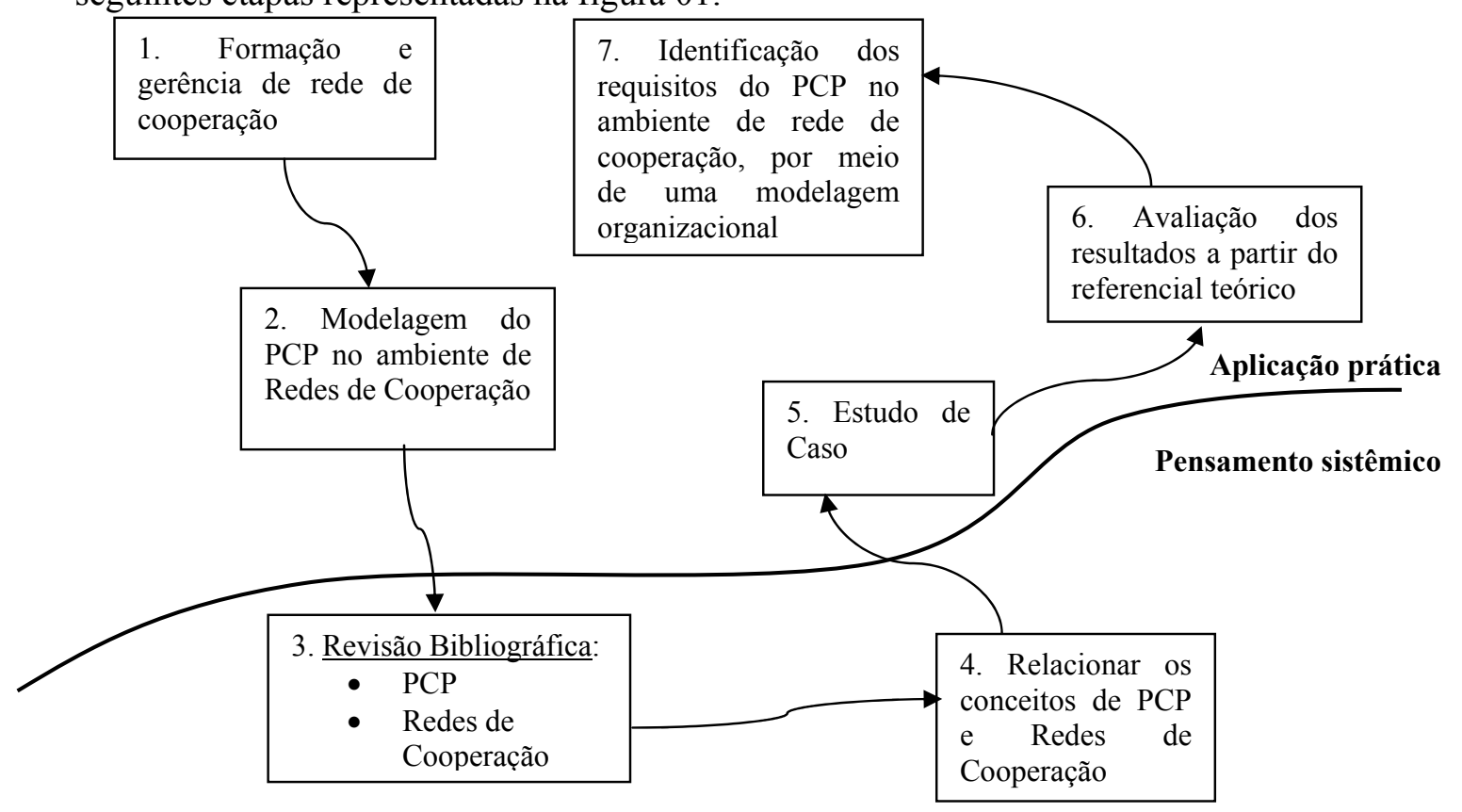

Figura 01: Etapas da pesquisa

Para formular e gerenciar uma rede de cooperação (1), é necessária a modelagem do PCP no ambiente de Redes de Cooperação (2). Para tanto necessita-se da identificação dos requisitos do PCP no ambiente de redes de cooperação (7). Antes, porém, através do pensamento sistêmico, deve-se delimitar o escopo a ser analisado, elaborando uma revisão bibliográfica para a compreensão do estado da arte sobre o tema, as metodologias propostas e possíveis desdobramentos sobre o escopo de desenvolvimento da pesquisa, compreendendo os processos na operação da rede, atividades e questões relacionadas ao PCP (3). Posteriormente, relacionam-se os conceitos de PCP e Rede de Cooperação utilizando-se uma metodologia de modelagem organizacional que forneça uma forma sistemática e controlada de analisar, entender, desenvolver e documentar uma organização e seus componentes (4). Em seguida, a aplicação prática é feita por meio do estudo de caso exploratório em obras de construção civil para a identificação das relações existentes entre empresas e a articulação com o PCP (5). Avaliam-se os resultados a partir do referencial teórico (6), que, através de ações e alterações, melhora a situação problemática culminando em uma modelagem do PCP no ambiente de Redes de Cooperação (7). 


\subsection{Estrutura do trabalho}

Este trabalho é apresentado conforme a seguinte estrutura:

Capítulo 2 - Apresenta uma revisão bibliográfica sobre os conceitos pertinentes ao referencial teórico adotado para o desenvolvimento do trabalho. É feita uma revisão sobre redes de cooperação entre empresas, morfologia da rede, ciclo de vida da rede e contrato de consórcio.

Capítulo 3 - Continua a revisão bibliográfica, apresentando e discutindo conceitos relacionados a processos de negócios, planejamento e controle da produção.

Capítulo 4 - Analisa a peculiaridade do sistema produtivo da construção, definindo e compreendendo o escopo e contornos de atuação do planejamento e controle da produção, no setor da construção civil. Este escolhido para o desenvolvimento do estudo de caso.

Capítulo 5 - O capítulo tem por objetivo introduzir e discutir conceitos relacionados à modelagem organizacional, focando na metodologia do EKD e propondo um modelo conceitual. Considerações relevantes sobre a modelagem de obras de construção civil são abordadas.

Capítulo 6 - Estudo de caso, que contempla um empreendimento de implementação da Linha 4 do Sistema de Metrô de São Paulo, e contém a elaboração dos projetos executivos civil e de sistemas, construção e execução das obras civil, vias e fornecimento e implantação de equipamentos e sistemas necessários.

Capítulo 7 - Elabora um modelo de PCP para consórcios de empresas, a partir do modelo conceitual proposto.

Capítulo 8 - Considerações Finais: resume as considerações finais sobre o presente trabalho de mestrado e apresenta proposta de futuros trabalhos. 
REVISÃO BIBLIOGRÁFICA 


\section{REDES DE COOPERAÇÃO ENTRE EMPRESAS: Morfologia, Ciclo de vida e Contrato de consórcio}

\subsection{Introdução}

Neste capítulo, é apresentada uma revisão bibliográfica dos principais assuntos relacionados a este trabalho, tendo por objetivo dar uma panorâmica do estado atual dos temas relacionados ao planejamento e controle da produção no ambiente de redes de cooperação assimétricas. Os principais temas do capítulo dizem respeito a redes de cooperação entre empresas, morfologia de redes, ciclo de vida de redes e contrato de consórcio.

Utilizam-se uma abordagem morfológica e o conceito de ciclo de vida a fim de compreender o recorte analítico de uma rede de cooperação produtiva assimétrica formalmente integrada, do tipo contrato de consórcio.

Um ponto importante na forma de abordar o ciclo de vida da rede é que ele segrega a existência da rede em fases e processos. Apesar de não serem todas as fases e todos os processos representativos para o escopo, é importante apresentar todo o ciclo para uma boa compreensão da dinâmica da rede. (GORANSON, 1999)

\subsection{Rede de cooperação entre empresas}

A empresa moderna procura constantemente aumentar a sua rentabilidade e reforçar a sua capacidade competitiva, adaptando-se às constantes alterações do mercado e procurando a sua dimensão ótima. Isso pode ser observado pelo movimento de aproximação entre empresas e corresponde à tendência de concentração da economia das últimas décadas. Nesse conceito se incluem, portanto, todas as formas de integração e de agregação, bem como as diversas modalidades de reunião de capacidades econômicas e tecnológicas. (VASCONCELOS, 1999)

Perante as várias formas de aproximação entre empresas, Vasconcelos (1999), por uma questão de simplicidade, divide-as em três grandes grupos: as que se traduzem num aumento da dimensão das unidades e na redução do seu número; as que se realizam pela subordinação econômica entre unidades juridicamente autônomas; e as que 
permitem uma aproximação entre empresas, mantendo, contudo, para cada uma, a autonomia jurídica e econômica. Tem-se, assim, a concentração na unidade, a concentração na pluralidade e a cooperação, respectivamente (VASCONCELOS, 1999).

Ou, segundo Amato (2000), a enorme pressão que as empresas vêm sofrendo para responder rapidamente ao mercado - ganhar flexibilidade, aprimorar sua capacitação tecnológica e gerencial, manter o acesso ao mercado e estar em sintonia com as mudanças internacionais - não lhes permite agir isoladamente, o que caracteriza a crescente importância das relações interfirmas e interinstitucionais.

A integração inter empresarial, isto é, a integração dos processos das diferentes empresas, está transformando-se em uma necessidade no mundo da manufatura como uma resposta às pressões impostas aos fabricantes. As condições essenciais para a integração parecem ser a confiança no fluxo livre, mas controlado, da informação e do conhecimento, e a coordenação das ações. A integração é uma maneira de quebrar as barreiras organizacionais, herança dos tradicionais princípios hierárquicos de gerência. (VERNADAT, 1996)

O termo rede de empresas geralmente recorre a uma vasta gama de relações interorganizacionais (NASSIMBENI,1998). Nesse sentido existem várias expressões referindo-se ao mesmo conceito ou dirigidas a diferentes abordagens - Empresa Estendida, Gerenciamento da Cadeia de Suprimentos, Comércio Eletrônico, Redes de Empresas, Cooperação Virtual, Cross Border Enterprise, Manufatura Ágil, etc. Elas podem não ser sinônimas, mas de alguma maneira endereçam conceitos semelhantes (CHAMBERS et al., 2000). Outras expressões que aqui podem ser incluídas são: Aliança Estratégica ${ }^{5}$ e Redes Interorganizacionais ${ }^{6}$ (WILLIAMS, 2002).

A Dinamarca cunhou o que se tornou o termo internacionalmente aceito para essas novas formas de cooperação: redes. Definindo a rede como três ou mais empresas que cooperam para ganhar força pela concentração de empresas, resolvendo problemas, entrando em mercados novos, ou desenvolvendo e produzindo bens (GELSING, 1992 apud ROSENFELD, 1996).

\footnotetext{
${ }^{5}$ Gebrekidan e Awuah (2002) abordadam Aliança Estratégica como uma manifestação de uma estratégica cooperação interorganizacional, com um formal ou informal arranjo entre duas ou mais companhias que, pela junção de suas habilidades e recursos, agregam força de forma a alcançar seus respectivos objetivos de negócios.

${ }^{6}$ Redes interorganizacionais são grupos de organizações, legalmente separadas, conectadas umas às outras através de um relacionamento de trocas, com objetivos comuns ou complementares, com um contrato ou relacionamento social que deve ser sustentado (WILLIAMS, 2002).
} 
O conceito de cooperação tem emergido da percepção que uma companhia não é uma ilha, mas sim parte de um mundo interdependente (PIRES et al. 2001).

Bremer e Ortega (2000) definem rede de cooperação como sendo um grupo de empresas que interagem pela troca de competências, indo além do relacionamento puro de compra e venda.

A rede de cooperação pode ser entendida como uma relação de cooperação que mantém uma interdependência entre as empresas, que se unem por objetivos lucrativos em comum, por exemplo, financiar uma pesquisa, introduzir novos produtos no mercado, realizar alianças oportunistas entre outros (AMATO, 2000).

O termo rede pode ser entendido como modelo de apresentação e/ou de pensamento para coletar, estruturar e coordenar os relacionamentos de uma empresa com clientes, fornecedores e concorrência (KATZY et al., 1996 apud CORRÊA, 1999), focando suas competências essenciais, obtendo outras partes da cadeia de valor de parceiros estratégicos (LEVIN, 1998).

Segundo New e Mitropoulos (1995), a idéia de rede é importante por apresentar uma alternativa à fadigada dicotomia do mercado contra a hierarquia. Realça a estabilidade natural de muitas relações comerciais, provê uma estrutura para a compreensão da difusão tecnológica além de promover o ganho de vantagem competitiva em pequenas empresas.

Embora as formas, os rótulos e os contextos teóricos para as relações de cooperação interorganizacional do tipo rede difiram, podem ser reconhecidas três características básicas na literatura (NASSIMBENI, 1998):

- A rede é constituída por duas ou mais empresas, ao menos em parte autônomas;

- A estrutura legal comumente usada para governar é o "contrato relacional";

- Entre as partes, formas dinâmicas de comunicação e coordenação (com mais intensidade do que a pessoa esperaria achar em trocas baseadas no mercado) são desenvolvidas de forma a adaptar e sincronizar a atividade de cada parte (nó) às atividades do sistema inteiro.

A cooperação interorganizacional é estimulada pelo crescente reconhecimento do fato de que nenhuma empresa ou organização tem todas as "capacidades" (recursos e atividades) necessárias para alcançar suas metas e objetivos no mercado (GEBREKIDAN e AWUAH, 2002). Neste contexto, Amato (2000) avalia que a cooperação interempresarial pode viabilizar o atendimento de uma série de necessidades 
das empresas, que seriam de difícil satisfação no caso em de atuarem isoladamente. Entre essas necessidades destacam-se (AMATO, 2000):

- combinar competências e utilizar know-how de outras empresas;

- dividir o ônus de realizar pesquisas tecnológicas, compartilhando o desenvolvimento e os conhecimentos adquiridos;

- partilhar riscos e custos de explorar novas oportunidades, realizando experiências em conjunto;

- oferecer uma linha de produtos de qualidade superior e mais diversificada;

- exercer uma pressão maior no mercado, aumentando a força competitiva em benefício do cliente;

- compartilhar recursos, com especial destaque aos que estão sendo subtilizados;

- fortalecer o poder de compra;

- obter mais força, para atuar nos mercados internacionais.

Grandori e Soda (1995) apresentam uma tipologia de redes interempresariais com base na compilação, e nos seguintes critérios: tipo de mecanismos de coordenação utilizados; grau de centralização da rede (simétrica ou assimétrica); grau de formalização dessa rede. Existem três tipos básicos: redes sociais (não unidas com acordos formais), redes burocráticas (caracterizadas pela existência de contrato formal) e redes proprietárias (caracterizadas pela formalização de acordos relativos ao direito de propriedade entre os acionistas de empresas) (GRANDORI e SODA, 1995).

Faria (2000) ressalta que, apesar de a escola européia mobilizar teorias de cooperação mais compatíveis com os princípios de descentralização e ter a potencialidade de melhor se ajustarem a "outras" realidades, o domínio da problemática de assimetria de poder entre fornecedores e clientes resulta em representações equivocadas sobre o papel real do ator-central em estruturas de redes, que é causa principal da negligência das teorias anglo-americanas pelos pesquisadores europeus.

Existem outras tipologias de redes na literatura, como a que Belussi e Arcangeli (1998) propõem, baseada na flexibilidade e formas de aprendizado. Dess (1995) propõe uma outra, considerando formatos típicos de organizações sem fronteiras (estrutura modular, estrutura virtual e estrutura livre de barreiras). Porter (1992) afirma existirem três tipos gerais de inter-relações possíveis (tangíveis, intangíveis e entre concorrentes) baseadas na cadeia de valores. Rosenfeld (1996) utiliza uma classificação básica: redes 
duras, que requerem uma cooperação formal e as redes suaves, que usualmente se mantêm informais. Corrêa (1999) divide as redes em três tipos: (1) rede estratégica, orientada para o mercado, que serve para a obtenção de certas metas e que é formada com a direção de uma empresa ao centro; (2) rede linear, que se adapta de acordo com a cadeia de valores; e (3) rede dinâmica; que se caracteriza por um intenso e variável relacionamento de empresas. A estrutura dessas três redes propostas por Corrêa (1999) pode ser observada na Figura 02.

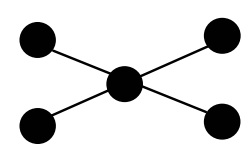

Rede Estratégica

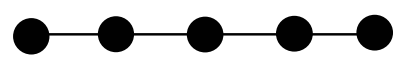

Rede Linear

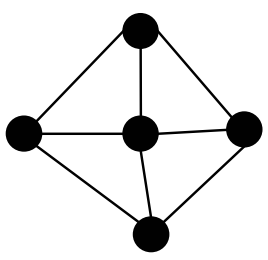

Rede Dinâmica

Figura 02: Tipos de redes de empresas Fonte: CORRÊA, 1999

As estruturas em rede constituem um quadro de referência que pode ser aplicável à investigação de múltiplos fenômenos caracterizados pela densidade de relacionamentos cooperativos entre os agentes, o que reforça a interdependência entre suas respectivas competências e impõe a necessidade de algum tipo de coordenação coletiva das ações adotadas (BRITTO, 2002).

A utilização do conceito de rede de cooperação pode ser relacionada a alguns elementos morfológicos que são comuns a esse tipo de estrutura. Britto (2002) aborda quatro elementos morfológicos genéricos, que podem ser ressaltados como partes constituintes das estruturas em rede: nós, posições, ligações e fluxos (Tabela 01).

Tabela 01 - Elementos estruturais das redes de empresas.

\begin{tabular}{l|l}
\hline $\begin{array}{l}\text { Elementos morfológicos gerais } \\
\text { das redes }\end{array}$ & $\begin{array}{l}\text { Elementos constitutivos das } \\
\text { redes de empresas }\end{array}$ \\
\hline Nós & $\begin{array}{l}\text { Empresas ou atividades } \\
\text { Estrutura de divisão do trabalho } \\
\text { Posições } \\
\text { Ligações }\end{array}$ \\
Fluxos & $\begin{array}{l}\text { (aspectos qualitativos) } \\
\text { Fluxos de bens (tangíveis) e de } \\
\text { informação (intangíveis) }\end{array}$ \\
\hline
\end{tabular}

Fonte: Britto, 2002.

Os nós constituem as unidades básicas das redes de empresas, que identificam as empresas inseridas na rede como unidades básicas a serem investigadas (BRITTO, 2002). 
As posições estão associadas a uma determinada divisão de trabalho que conecta os diferentes agentes visando atingir determinados objetivos, e que envolve a integração de capacidades operacionais e competências organizacionais dos agentes (BRITTO, 2002). Gebrekidan e Awuah (2002) argumentam sobre a importância da posição (definida como a direta ou indireta relação com os outros específicos atores) que cada ator $^{7}$ (empresa, organização e indivíduos) cria para si. A posição do ator é estabelecida e desenvolvida a todo o momento, por meio de investimentos em processos ${ }^{8}$ (GEBREKIDAN e AWUAH, 2002).

A posição do ator na rede dá a ele algum poder sobre certas atividades da rede. O poder, por outro lado, advém do controle direto que o ator detém sobre as suas atividades e do controle indireto sobre as outras atividades, por meio do relacionamento com os outros atores. (GEBREKIDAN e AWUAH, 2002)

Neste contexto, Williams (2002) afirma que a localização de cada organização e seu contato na estrutura da rede definem as chances da organização obter benefícios.

As ligações entre os nós constituintes podem ser dispersas (número de ligações entre pontos é bastante limitado) ou saturadas (cada ponto está ligado a praticamente todos os demais pontos da rede) possibilitando a determinação da densidade da rede além do grau de centralização da estrutura (BRITTO, 2002).

Os fluxos que circulam pelos canais de ligação entre os nós são representados por bens (tangíveis) e informações (intangíveis) (BRITTO, 2002).

Para Mizruchi e Galaskiewicz (1993), as redes de empresa são um meio de reduzir custos de transação, de forma que a entrada no mercado assuma custos e riscos conjuntamente. As grandes empresas têm optado por desenvolverem-se como servidores estratégicos da rede (que coordenam as funções dos membros da rede), podendo ser a chave para um futuro sucesso (LEVIN, 1998) Ou seja, admitindo-se que se consiga reformar e transformar sua organização em uma rede articulada de centros multifuncionais de processos decisórios, a empresa de grande porte, sem dúvida, poderá ser uma forma superior de gerenciamento na nova economia (CASTELLS, 1999). A empresa central deve analisar as capacidades das empresas periféricas, pois estas se situam na maior proximidade das preferências da demanda (MIZRUCHI e GALASKIEWICZ, 1993).

\footnotetext{
${ }^{7}$ Analogia direta ao elemento morfológico definido por Britto (2002) como Nó.

${ }^{8}$ Processo pode ser definido como um conjunto de atividades interdisciplinares e/ou interdepartamentais realizadas em uma seqüência lógica que geram uma saída de valor para o cliente (GONÇALVES, 1997). Conceito que será abordado com maior ênfase no tópico 3.2
} 
No âmbito da manufatura, as empresas têm se organizado em efetivas arquiteturas do sistema de produção, de forma a satisfazer as necessidades do mercado, como a manufatura virtual, empresa enxuta e empresa ágil (CAMARINHA-MATOS e AFSARMANESH, 1999b), existindo diferentes abordagens e diferentes nomes para produção ou sistemas de manufatura distribuída, que definem basicamente uma rede flexível de unidades autônomas de manufatura cooperando entre si (MEZGÁR et al., 2000). Existe, assim, uma tendência para que o processo de manufatura não seja executado por uma única empresa, mas que cada empresa seja um ponto a acrescentar valor a todo o ciclo de produção (CAMARINHA-MATOS e AFSARMANESH, 1999a).

Com o avanço rápido da eletrônica e das tecnologias de comunicação, pesquisas de âmbito mundial estão sendo feitas para modelar, construir e testar redes industriais ágeis, virtuais e distribuídas, entre empresas autônomas que compartilham informações da manufatura e recursos (LEE e LAU, 1999).

Uma efetiva cooperação requer coordenação, uma vez que independentes atores (membros de uma rede) possuem comportamentos e prioridades diferentes, motivações (podendo até mesmo competir em alguns pontos) e percepções diferentes do ambiente onde estão inseridos, mostrando que a coordenação é necessária para prevenir a "anarquia" e a "ineficiência", de modo que as empresas possam vir a alcançar seu objetivo comum (CAMARINHA-MATOS e LIMA, 1999).

As formas de conexão e coordenação devem ser definidas balanceando duas necessidades contrastantes (NASSIMBENI, 1998):

- Mecanismos de coordenação não devem ser tão rígidos a ponto de os nós ficarem robustos, levando ao colapso da estrutura em rede, uma vez que a flexibilidade deles garante o envolvimento integrado de unidades independentes.

- Os mecanismos de coordenação devem fazer que as atividades de cada nó estejam sincronizadas com todo o sistema.

Fazendo um paralelo com o trabalho de Mintzberg $(1979,1995)$ e com as três principais categorias, genericamente referidas ao termo "rede", que diferem quanto aos objetivos (redes de suprimento, joint-ventures e sistemas de industria regional), Nassimbeni (1998) aborda os seguintes mecanismos de coordenação:

- Supervisão direta. Neste caso, um nó central coordena e direciona as ações do sistema, supervisionando e sincronizando as outras unidades. 
- Padronização. Consiste na predefinição e codificação das tarefas de cada unidade, que são parte de padronizações específicas.

- Ajustamento mútuo. Ocorre particularmente nos primeiros estágios de vida da rede, quando as unidades estão procurando seu posicionamento na rede, e permite uma definição mais precisa das tarefas dentro dela.

Uma vez que a busca da competitividade relaciona-se cada vez mais com a busca do ótimo sistêmico dentro e fora das fronteiras da empresa (WOOD JR. e ZUFFO, 1998), é importante considerar as várias fases do ciclo de vida da rede ao analisar as infraestruturas requeridas para rede entre empresas.

\subsection{Ciclo de Vida da Rede de Cooperação}

O Agile Manufacturing Enterprise Forum (AMEF) propõe um modelo genérico que serve como guia de referência para a formação de rede de cooperação. Segundo Goranson (1999), o modelo é uma matriz onde, de um lado, estão os processos associados ao ciclo de vida da rede e, do outro, estão as chamadas infra-estruturas ou áreas de aplicação, como na Figura 03.

São quatro as infra-estruturas onde os aspectos de uma cooperação entre empresas e sua coordenação devem ser tratados. Os mecanismos de coordenação devem ser associados de acordo com o conhecimento dessas infra-estruturas e seu relacionamento entre si (GORANSON, 1999).

\begin{tabular}{|c|c|c|c|c|c|c|}
\hline CICLO DE & \multicolumn{2}{|c|}{ PROCESSOS DE UMA REDE } & \multicolumn{4}{|c|}{ INFRA-ESTRUTURA } \\
\hline \multirow{4}{*}{$\begin{array}{l}\text { Identificação } \\
\text { Oportunidade }\end{array}$} & 1.1 & Estratégia de Oportunidade & \multirow{21}{*}{ 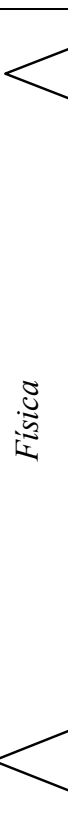 } & & & \\
\hline & 1.2 & Exposição & & & & \\
\hline & 1.3 & Marketing & & \multirow{17}{*}{$\begin{array}{l}\overline{1} \\
8 \\
0\end{array}$} & \multirow{17}{*}{ 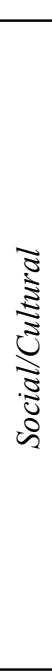 } & \\
\hline & 1.4 & Busca de Oportunidade & & & & \\
\hline \multirow{3}{*}{ Busca Parceiros } & 2.1 & Qualificação de Parceiros & & & & \\
\hline & 2.2 & Históricos de Desempenho & & & & \\
\hline & 2.3 & Busca de Parceiros & & & & \\
\hline \multirow{8}{*}{ Formação } & 3.1 & Visão/Estratégia & & & & \\
\hline & 3.2 & Critério de Seleção & & & & \\
\hline & 3.3 & Métricas de Empresas & & & & త్ర \\
\hline & 3.4 & Capitalização & & & & $\stackrel{5}{\mathfrak{\Sigma}}$ \\
\hline & 3.5 & Garantias de Produtos & & & & $\stackrel{2}{5}$ \\
\hline & 3.6 & Estratégias de Retorno & & & & \\
\hline & 3.7 & Estrutura Operacional & & & & \\
\hline & 3.8 & Plano de Dissolução & & & & \\
\hline \multirow{3}{*}{ Operação } & 4.1 & Medidas de Desempenho & & & & \\
\hline & 4.2 & Relações com Clientes & & & & \\
\hline & 4.3 & Práticas Operacionais & & & & \\
\hline \multirow{3}{*}{$\begin{array}{c}\text { Dissolução/ } \\
\text { Reconfiguração }\end{array}$} & 5.1 & Identificação de Necessidades & & & & \\
\hline & 5.2 & Garantias Residuais & & & & \\
\hline & 5.3 & Resíduos e Equidades & & & & \\
\hline
\end{tabular}

Figura 03: Estrutura Agile Virtual Enterprise Adaptado: GORANSON, 1999 
As cinco principais fases do ciclo de vida da rede proposta por Goranson (1999) são as seguintes:

- Identificação da Oportunidade: Um líder em potencial ou um grupo de especialistas possui a responsabilidade de identificar, refinar e/ou caracterizar a oportunidade de negócio;

- Busca de Parceiros: Uma vez que a oportunidade foi identificada, é necessário encontrar os parceiros adequados para atuar na rede;

- Formação: Após a identificação da oportunidade e seus parceiros, é necessário elaborar um Business Case detalhado;

- Operação: Depois de estabelecida a rede, ela deve ser operacionalizada, ou seja, colocada em funcionamento;

- Dissolução/Reconfiguração: Em certo ponto preestabelecido, a oportunidade terá sido explorada integralmente ou necessitará ser modificada.

As quatro infra-estruturas definidas no modelo são (GORANSON,1999):

- Informação: Inclui mecanismos usados para criar, administrar e comunicar informação na rede;

- Social/Cultural: Refere-se às regras implícitas e explicitas e questões políticas existentes na organização. As regras de negócio associadas à supervisão são partes dessa infra-estrutura. A política, incluindo acordos trabalhistas e hábitos, é parte da cultura corporativa.

- Legal: Relaciona-se com processos que lidam com instrumentos legais. Internamente tais instrumentos são cláusulas contratuais; externamente, eles são formados pelos códigos, leis e regulamentações. Dentro desta questão, encontra-se o problema de supervisão da programação e controle de atividades. Redes de supervisão e papéis de decisão são incluídos.

- Física: Relaciona-se com a fabricação, equipamentos, layout, transportes, manipulação ou quaisquer características físicas da rede.

É importante apontar o fato de que outros ciclos de vida, modelos e interpretações são encontrados na literatura.

Vilkano e Keil (2003) mostram que a relação entre empresas pode ser organizada ao longo do ciclo de vida de uma aliança, podendo ser dividida em três partes: formação, operação e término da aliança. 
A Agile Aerospace Manufacturing Research Center (AAMRC) propõe um modelo para um relacionamento temporário entre dois ou mais parceiros, que é formado, operacionado e dissolvido visando objetivos específicos de curto prazo (REID et al., 1996a apud GOULART, 2000). O ciclo de vida proposto pelo modelo da AAMRC é composto por seis etapas (REID et al., 1996b apud GOULART, 2000):

- Concepção: Uma Empresa Virtual (EV) surge ao identificar uma necessidade de mercado e ao estabelecer um objetivo.

- Criação: São estabelecidos os relacionamentos entre os parceiros possuidores das competências requeridas para conceber o produto que satisfaça a necessidade de mercado identificada.

- Competição: É feita a divulgação do produto no mercado.

- Configuração: A EV é configurada a partir da aquisição dos ativos e competências necessárias.

- Condução: A EV começa a operar produzindo e entregando seu produto.

- Conclusão: Ao alcançar os objetivos, a cooperação é finalizada, ocorrendo a dispersão ou reaproveitamento dos ativos envolvidos.

A Empresa Virtual é um tipo particular de rede entre empresas que pode ser definida como uma aliança ou consórcio temporário de companhias formado para dividir custos, e agregar recursos e habilidades ou competências essenciais, para uma melhor resposta às oportunidades de mercado (CAMARINHA-MATOS e AFSARMANESH, 1999a). Todavia, essa definição se apresenta ampla e viável à análise de outras relações intra ou interempresas.

Neste sentido, a proposta de Camarinha-Matos e Afsarmanesh (1999a,b) pode servir como modelo para outras abordagens de redes de cooperação entre empresas. Inclui as seguintes fases:

- Criação/Configuração. Seleção de parceiros, contrato de compromisso, definição de direitos de acesso e nível de compartilhamento, definição e configuração dos processos de conexão das partes. A problemática da seleção dos parceiros deve ser decomposta em dois grupos: parceiros essenciais, responsáveis pelos componentes e serviços críticos, e parceiros subsidiários que suprem componentes e serviços de menor importância.

- Operação. Esta é a fase na qual a Empresa Virtual está moldando seus processos de negócios de forma a atingir os objetivos comuns, requerendo 
funcionalidades do tipo: Gerenciamento de pedidos; Planejamento e programação distribuídos e dinâmicos; Gerenciamento distribuído das tarefas; Alto nível de coordenação das tarefas. Observa-se que, para dar suporte aos vários níveis de interação entre os membros da Empresa Virtual, o PCP (Planejamento e Controle da Produção) é acrescido por uma camada suporte.

- Evolução/Reconfiguração. Quando ocorre algum evento excepcional durante a fase de operação, como a incapacidade momentânea de algum parceiro ou a necessidade de aumentar a força de trabalho, evidencia-se a necessidade de uma evolução ou reconfiguração da rede acrescentando ou realocando um parceiro.

- Dissolução. Esta é fase na qual a Empresa Virtual encerra seus processos de negócio e desmantela-se.

A diferença básica das Empresas Virtuais para outros modelos de cooperação é a freqüência e intensidade da cooperação, ou seja, a configuração, dissolução e reconfiguração acontecem repetidamente em um período relativamente curto de tempo (BREMER, 1996).

Pires et al. (2001) observam que um ponto pertinente em relação a reconfiguração de parceiros, que pode ser considerado como um critério de reconfiguração, é a estrutura contratual. Toda rede de organizações consiste em uma teia de formas de contrato, sendo dependente das leis do país ou países nos quais a organização opera. Entretanto, pode-se estabelecer um critério que considera as diferenças contratuais. (PIRES et al., 2001)

Constitui, segundo Penteado (1990), uma visão muito limitada esquecer que o consórcio, hodiernamente, seja considerado como a fórmula jurídica mais flexível e adaptável para plasmar qualquer forma de colaboração entre empresários, sem a necessidade da constituição de uma nova sociedade. Qualquer modalidade de colaboração que consiste em tornar comum a exploração de um serviço, ou de uma ou mais fase do ciclo das empresas, pode encontrar no consórcio o modelo propício. Remanesce, com essa espécie de contrato intersocietário, a autonomia econômica e jurídica das empresas participantes, auferindo elas, por meio da organização instituída, desprovida de personalidade jurídica, os influxos diretos dos resultados da atividade em comum. (PENTEADO, 1990) 
Neste contexto, na atualidade, ganham particular relevo os instrumentos jurídicos que tornam possível e institucionalizam a colaboração ou cooperação entre as empresas. A realidade econômica, desde sempre, tem solicitado ao direito o suporte jurídico para a realização dos seus fins. (VASCONCELOS, 1999)

\subsection{Contrato de Consórcio}

Vários autores se reportam à necessidade de fixação de mecanismos de coordenação, ora denominado de infra-estrutura legal ${ }^{9}$, ou mais adequadamente atribuído como infra-estrutura jurídica, ora se reportando simplesmente a um contrato. Conceituando-se o contrato como: o acordo de duas ou mais pessoas para, entre si, constituir, regular ou extinguir uma relação jurídica de natureza patrimonial. (OLIVEIRA, 2000)

Dentre as várias modalidades de contratos cabe destacar, segundo o escopo deste trabalho, aqueles em que não há alteridade, ou seja, existência de interesses contrapostos, mas um objetivo comum almejado pelas partes contraentes, com particular destaque para os contratos de consórcio.

Consórcio é o contrato feito pela companhia e outras sociedades com a finalidade de executar determinado empreendimento (OLIVEIRA, 2000).

A importância do contrato pode ser ressaltada, uma vez que eles são caracterizados como mecanismos reguladores de transações, usados para reduzir riscos e incertezas em processos de troca (LUSCH e BROWN, 1996 apud NEVES, 2002). Sua análise diz aos interessados, com autoridade, como regular o comportamento das empresas em contratos (NEVES, 2002), além do fato de que contratos incompletos podem dar margem a ações oportunistas por uma das partes (WILLIAMSON, 1985 apud NEVES, 2002).

São cinco as causas de deficiência nos contratos (SCWHARTZ, 1992; TIROLE, 1992 apud NEVES, 2002):

- O contrato pode ser vago ou ter ambigüidade em palavras;

- Alguma das partes inadvertidamente falha em algum aspecto;

- Os custos de produção do documento superam os custos de resolução de problemas futuros;

\footnotetext{
${ }^{9}$ Terminologia também abordada por Goranson (1999).
} 
- Presença de informação assimétrica, ou seja, uma das partes detém mais informação que a outra;

- Preferência de uma das empresas em sair do relacionamento.

O contrato de consórcio é apenas uma das formas a que se pode recorrer para obter a cooperação entre agentes econômicos. De fato, há outras vias, com características diferentes, mas que se podem considerar afins do contrato de consorcio ${ }^{10}$, como podemos apontar de forma exemplificativa, no direito comparado: As unincorporated joint venture do Direito Norte Americano; Os groupements d'entreprises do Direito Francês; A association momentanée do Direito Belga. (VASCONCELOS, 1999)

A modalidade de consórcio equivale ao consortium definido por Berwanger (1999) apud Oliveira, (2000), que apresenta como desvantagem o fato de que nenhuma das empresas garante ao cliente ou consumidor o desempenho total e integrado das missões assumidas por cada uma delas, sendo constituídas basicamente para atender grandes projetos industriais. Segundo Penteado (1990), as joint ventures podem revestirse de formas jurídicas variadas, aqui e alhures, dentre as quais se inclui, no Brasil, o consórcio (regido pela Lei 6.404, 15.12.76, Capítulo XXII, arts. 278 e 279). Atualmente é grande a difusão dos contratos joint venture e das joint ventures corporations e seu escopo é o de aprimorar as formas de cooperação industrial (OLIVEIRA, 2000).

Nesse contexto, os interesses a que o contrato de consórcio vem dar resposta não são exclusivos dos agentes econômicos de um país. Verifica-se, na generalidade dos países, nomeadamente o interesse de estabelecer formas de cooperação empresarial, com as características que o consórcio possui. Consideram-se como figuras semelhantes àquelas que associam, sem relações de subordinação jurídica e/ou econômica, diferentes pessoas jurídicas, com uma finalidade em comum, não dando lugar à criação de uma nova pessoa jurídica não exigindo o exercício em comum de qualquer atividade. (VASCONCELOS, 1999)

\footnotetext{
${ }^{10}$ Uma figura que coloca dificuldades de classificação é o consórcio regulado pela Lei brasileira. De fato, os artigos $278^{\circ}$ e $279^{\circ}$ da Lei Brasileira das Sociedades Anônimas (Lei no 6404, de 15 de dezembro de 1976) contêm a disciplina do "contrato de consórcio". De acordo com estas normas, o "consórcio" não possui personalidade jurídica e, pelo fato de estar regulado numa lei cujo objetivo são as sociedades anônimas, desde logo, apenas pode ser celebrado por este tipo de sociedade. O "consórcio" tem um objeto limitado e determinado, o qual deve consistir na execução de determinado empreendimento, e as empresas que o constituem não assumem responsabilidade solidária. Cada consorte responde pelas suas obrigações, sem sequer se presumir a solidariedade.
} 
No Brasil, a prática de consórcios de empresas é suportada pelo Capítulo XXII da Lei 6404, de 15 de dezembro de 1976 (nos artigos 278 e 279, transcritos a seguir), que erige como modalidade de combinação de empresas para a consecução de empreendimentos conjuntos das variadas finalidades ${ }^{11}$ (LEÃO, 2000).

“Art. 278. As companhias e quaisquer outras sociedades, sob o mesmo controle ou não, podem constituir consórcio para executar determinado empreendimento, observando o disposto neste Capítulo.

$\S 1^{\circ}$. O consórcio não tem personalidade jurídica e as consorciadas somente se obrigam nas condições previstas no respectivo contrato, respondendo cada uma por suas obrigações, sem presunção de solidariedade.

$\S 2^{\circ}$. A falência de uma consorciada não se estende às demais, subsistindo o consórcio com as outras contratantes; os créditos que porventura tiver a falida serão apurados e pagos na forma prevista no contrato de consórcio.

Art. 279. O consórcio será constituído mediante contrato aprovado pelo órgão da sociedade competente para autorizar a alienação de bens do ativo permanente, do qual constarão:

I- a designação do consórcio, se houver;

II - o empreendimento que constitua o objeto do consórcio;

III - a duração, endereço e foro;

IV - a definição das obrigações e responsabilidade de cada sociedade consorciada, e das prestações específicas;

$V$ - normas sobre recebimento de receitas e partilhas de resultados;

$V I$ - normas sobre administração do consórcio, contabilização, representação das sociedades consorciadas e taxa de administração, se houver;

VII - forma de deliberação sobre assuntos de interesse comum, com o número de votos que cabe a cada consorciado;

VIII - contribuição de cada consorciado para as despesas comuns, se houver.

Parágrafo único. O contrato de consórcio e suas alterações serão arquivadas no Registro do Comércio do lugar da sua sede, devendo a certidão do arquivamento ser publicada”.

\footnotetext{
${ }^{11}$ Existem manifestações legislativas específicas para a formação de consórcios em alguns setores, como o mercado de capitais (Lei 4.728/65), os consórcios de exportações (Lei 5.025/66) e a participação em licitações (Lei 8.666/93).
} 
Deve esse contrato ser aprovado pelo órgão da sociedade que tiver competência para autorizar a alienação de bens do ativo permanente, e dele constarão a designação do consórcio, se houver, o empreendimento que constituir seu objeto, a duração, endereço e foro, as obrigações e responsabilidades e as prestações específicas de cada sociedade consorciada. Figurarão ainda as normas relativas à administração, se houver. (OLIVEIRA, 2000)

Deve, ainda, o contrato estipular a forma de deliberação consorciada e a contribuição, se houver, de cada consorciada para as despesas comuns, sendo requisito contratual facultativo (PENTEADO, 1990; OLIVEIRA, 2000). Esse contrato, bem como suas alterações, deve ser arquivado no Registro do Comércio do local da sede do consórcio, sendo publicada a certidão do arquivamento (OLIVEIRA, 2000).

O consórcio não tendo personalidade jurídica, as consorciadas respondem apenas pelas obrigações assumidas, sem presunção de solidariedade. A falência de uma consorciada não se estende às demais, permanecendo o consórcio com as outras contratantes, os créditos que a falida tiver no consórcio serão apurados e pagos na forma do contrato. (OLIVEIRA, 2000)

Leão (2000) argumenta que esta orientação, que é extremamente útil do ponto de vista comercial, não é juridicamente a melhor, uma vez que, na falta de personalidade, não há a constituição de um patrimônio em separado, e os consorciados deveriam responder todos, ilimitadamente, pelas dívidas que porventura tivessem coletivamente assumido para com os terceiros.

A obrigação principal que emerge do contrato é a de cada membro do consórcio concertar e articular a sua atividade com a dos restantes membros, para através dessa ação conjunta se atingir a finalidade que o consórcio elegeu como fim comum. Cada consorciado, isoladamente considerado, continua a desenvolver as atividades que lhe são próprias, com total autonomia, mas com sintonia, em articulação de esforços com os restantes elementos do consórcio. (VASCONCELOS, 1999; LEÃO, 2000)

Os consórcios de empresas são, portanto, grupos ou reorganizações entre quaisquer companhias ou sociedades, que desejam se unir para a execução de qualquer empreendimento sem, todavia, estabelecer um vínculo mais rígido ou permanente (na forma de uma fusão ou incorporação), ou pela criação de uma sociedade, sendo tipificado, no Brasil, na Lei das Sociedades Anônimas como um contrato (LEÃO, 2000). 
Está-se, deste modo, em presença de uma forma de cooperação entre empresas de caráter temporário, limitada a objetivos concretos e determinados, sendo esta a forma mais lassa que o legislador arquitetou para estruturar a cooperação interempresarial para objetivos comuns (VASCONCELOS, 1999).

Essencial é a existência da vontade de cooperar, de colaborar, concretizada em um contrato entre os diversos interessados, que depois podem recorrer a diferentes instrumentos jurídicos, típicos ou atípicos, como forma de concretizar as ações de cooperação entre eles (VASCONCELOS, 1999).

Em relação ao gerenciamento do consórcio, após o estabelecimento do acordo de constituição, pode-se observar que, apesar de as negociações iniciais já terem estabelecido os parâmetros básicos de atuação, o aspecto dinâmico da realidade individual de cada consorciado, bem como do próprio empreendimento conjunto, obriga a continuidade permanente do processo de negociação, na busca do que poderia se chamado de equilíbrio dinâmico (LEÃO, 2000).

Nesse sentido, Nandler et al. (1994) apud Leão (2000) lembram que, após a análise de oportunidade estratégica e identificação do possível parceiro, toda a atenção deve estar voltada para o acordo de formação. Para esses autores, algumas questões devem ser necessariamente incluídas:

1. missão do consórcio;

2. objetivos de curto e longo prazos;

3. mercados a serem atendidos;

4. produtos e serviços a serem oferecidos;

5. estrutura organizacional básica do empreendimento;

6. obrigações e responsabilidades dos consorciados;

7. responsabilidades administrativas do empreendimento;

8. definição de papéis;

9. processo de dissolução do consórcio.

A compreensão dos elementos envolvidos no contrato de consórcio é de grande interesse para o gerenciamento do consórcio e busca do equilíbrio dinâmico.

Vasconcelos (1999) aborda os seguintes elementos do contrato de consórcio:

- Sujeitos ou partes ${ }^{12}$ - O consórcio é um contrato plurilateral (celebrado por duas ou mais partes) sem que se estabeleça entre as partes relação de

\footnotetext{
${ }^{12}$ Sujeitos ou partes são análogos ao conceito de Nós observado no trabalho de Britto (2002).
} 
subordinação, domínio ou de grupo. As partes devem agir em pé de igualdade, o que não implica que sejam necessariamente iguais em estatuto jurídico, em capacidade econômica ou técnica, ou no que diz respeito à posição que ocupam no mercado.

- Requisitos de atividade econômica exercida por cada uma das partes ou sujeitos $^{13}$. São requisitos que não estão em oposição com a atividade que é desenvolvida pelos demais. Ou ainda que não se opõem aos fins do próprio consórcio criado pelas partes ou em conflito com os objetivos consorciais, nomeadamente o fim da cooperação entre as partes.

- Susceptível de graus ${ }^{14}$ - As relações de cooperação que se estabelecem entre as partes não têm todas a mesma intensidade. Decorre que a intensidade da cooperação varia de acordo para acordo e, dentro do mesmo, tende a evoluir ao longo da sua duração.

- Obrigação de boa fé - Estas obrigações concretizam-se, nomeadamente, no dever de informação, no dever de sigilo quanto a informações obtidas e cuja divulgação possa causar prejuízos às restantes partes envolvidas no negócio, e nos deveres de assistência e de proteção em relação às outras partes, estando ainda obrigadas a especiais deveres de informação e esclarecimento sobre todos os aspectos relevantes acerca de cada uma das partes e do negócio a celebrar.

- Caráter evolutivo - Dado o tipo de objeto que faz parte destes acordos, dificilmente, à partida, seria possível determinar todas as obrigações concretas que sobre cada uma das partes recairia. Desse modo, as partes têm que aceitar o seu caráter evolutivo, e a capacidade de o ir adaptando e modificando à medida que vai sendo executado. Essa é uma condição decisiva para estabelecer um espírito de confiança entre as partes, apesar de na prática poder suscitar bastantes problemas. Por isso, é também importante que o contrato preveja formas amigáveis de resolução dos eventuais problemas e formas de superar os impasses.

- Ponto de vista produtivo - O contrato de consórcio tanto pode reunir sujeitos que exercem atividades similares, da mesma especialidade, como sujeitos

\footnotetext{
${ }^{13}$ Requisitos de atividade econômica exercida por cada uma das partes ou sujeitos é análogo ao conceito de posições observado no trabalho de Britto (2002).

14 Susceptível de graus possui analogia com o conceito de ligações observado no trabalho de Britto (2002).
} 
que exercem atividades distintas, mas complementares entre si. No primeiro caso, tem-se consórcios horizontais, que ocorrem entre empresas do mesmo ramo ou similares, que surgem quando a empreitada a realizar não é decomponível em diferentes especialidades e as partes pretendem obter uma soma de meios técnicos e/ou financeiros, que tornem possível a execução de uma obra que nenhuma por si só poderia realizar. No segundo - consórcios verticais - ocorre quando os interesses das partes são repartir competências e tarefas. De acordo com a especialidade de cada empresa, da contribuição das várias especialidades resultará a execução da empreitada, objeto do consórcio.

Pelo que fica exposto, Vasconcelos (1999) conclui que no contrato de consórcio se encontram os elementos que caracterizam os contratos de cooperação entre empresas. Ou seja, trata-se de um contrato que nasce da existência de um animus cooperandi entre as partes, que é potencialmente plurilateral, que possui um escopo comum e pode ter um caráter evolutivo. As partes encontram-se numa posição de igualdade em face ao objetivo contratual, e entre elas existe uma obrigação de boa fé reforçada. (VASCONCELOS, 1999)

De acordo com Casarotto (2002), os consórcios podem ser divididos de acordo com suas funções principais, por meio da determinação dos objetivos, tipos de serviços e atividades a que o consórcio se destina.

Podem-se citar quatro principais grupos de consórcios (CASAROTTO, 2002):

a) Consórcios setoriais - São aqueles em que empresas concorrentes e complementares, (eventualmente unidas às empresas e instituições que constituem a cadeia de valor relativa ao setor) realizam um acordo que permite o ganho de competitividade dos membros através da difusão de informações e a complementaridade produtiva das pequenas empresas;

b) Consórcios territoriais - São consórcios que agremiam empresas de todos os setores e atividades de um território e ocupam-se principalmente de atividades informativas e de promoção do conjunto dessas empresas e do território de inserção;

c) Consórcios específicos - Restringem sua ação às atividades específicas para atingir um objetivo pontual determinado. Os mais clássicos exemplos são os consórcios de exportação, que agem na promoção das empresas e no ganho 
de competitividade orientado à penetração em específicos mercados externos. Outro exemplo seria um consórcio de compras conjuntas;

d) Consórcios temporários - São consórcios com duração limitada ao objetivo. O exemplo mais forte é dado por empresas de construção civil que se associam para empreenderem uma obra de grande porte que exija escala de produção e competências só obtidas através da soma das empresas participantes. Um consórcio para desenvolvimento de um produto ou de uma tecnologia é outro exemplo.

As características legais e estruturais do consórcio deverão ser uma conseqüência do seu desenho, isto é, derivadas do acordo entre as empresas, dos objetivos do consórcio, dos tipos de serviços desenvolvidos e da profundidade dos mesmos. Vale relembrar que uma rede não significa um consórcio. Ela pode ser puramente comercial. O consórcio começa a se formar quando os participantes "assinam" um pacto em torno das disciplinares do consórcio. As disciplinares são as regras de conduta envolvendo responsabilidades, ética, diretrizes de qualidade, graus de liberdade, etc... (CASAROTTO, 2002)

\subsection{Considerações finais}

Para o escopo deste trabalho, analisa-se o contorno do Planejamento e Controle da Produção distribuído, para uma rede produtiva de empresas, abordando o ciclo de vida da rede, e agregando a ele a morfologia proposta por Britto (2002), que representa um recorte analítico das estruturas em rede, além dos contornos representativos do conceito de contrato de consórcio.

Uma vez que, partindo-se de uma abordagem geral, pode-se convergir às fases e processos representativos ao escopo, focando nas funcionalidades e requisitos de um planejamento e programação da produção distribuídos e dinâmicos. 


\section{A IMPORTÂNCIA DO PROCESSO DE NEGÓCIO NO PLANEJAMENTO E CONTROLE DA PRODUÇÃO (PCP) DISTRIBUÍDA.}

\subsection{Introdução}

Dentre as características que se podem destacar dos processos de negócio no tratamento das redes, tem-se o fato de serem transorganizacionais além de promoverem a materialização das políticas gerenciais, dos fluxos de informações, dos procedimentos operacionais e dos processos de manufatura. Dessa forma, o processo de negócio "produzir", destaca-se demonstrando ser essencial para a obtenção do produto, com reflexos críticos no resultado final da empresa.

O Planejamento e Controle da Produção mostra-se intimamente integrado ao processo de negócio Produzir, uma vez que ele processo é responsável por planejar e adquirir os recursos necessários a fim de converter entradas em produtos (GOULART, 2000).

Com o intuito de se determinar às atividades do Planejamento e Controle de uma Produção distribuídos para converter em modelo, apresenta-se uma revisão com as principais atividades do PCP e caracterizam-se as diferentes classificações do sistema de produção, já que o tipo de empresa e o tipo de produto moldam as características principais do PCP.

\subsection{Processos de Negócio}

Para Rotondaro (1997, p.59), processo é "uma seqüência organizada de atividades, que transforma as entradas dos fornecedores em saidas para os clientes, com um valor agregado pela unidade". Portanto, a geração de um produto ou serviço para um cliente é realizada pela cadeia de um ou mais processos interligados, existindo uma relação entre clientes e fornecedores internos (Figura 04). Os processos são unidades coesas em termos de organização, de pessoal e de processamento de informação, orientadas para um tipo específico de negócio da empresa (RENTES, 1995). 
Todo trabalho importante realizado nas empresas faz parte de algum processo (GRAHAM e LeBAROM, 1994). Não existe um produto ou um serviço oferecido por uma empresa sem um processo empresarial. Da mesma forma, não faz sentido existir um processo empresarial que não ofereça um produto ou um serviço. A lógica de funcionamento das empresas está passando a acompanhar a lógica dos processos e não mais o raciocínio compartimentado da abordagem funcional. (GONÇALVES, 2000a)

Essa idéia de processos como um fluxo de trabalho, com entradas e saídas claramente definidas e tarefas discretas que seguem uma seqüência e que dependem umas das outras numa sucessão clara, vem da tradição da engenharia. As transformações ocorridas num processo podem ser físicas, de localização e transacionais (transformação de itens intangíveis). (GONÇALVES, 2000a)

A definição de processo pela descrição da transformação de entradas em saídas de valor não é suficiente, uma vez que um processo típico também envolve paradas, transformações, retorno e repetibilidade (GONÇALVES, 2000a). Nem sempre os processos empresariais são formados por atividades claramente delineadas em termos de conteúdo, duração e consumo de recursos definidos, além de não precisarem ser consistentes ou realizados numa seqüência particular (MORRIS e BRANDON, 1994).

O objetivo final é a consecução do produto ou serviço para o cliente final. Deste modo, toda análise e decisões dos problemas que ocorrerem nas interfaces clientesfornecedores internos devem ser resolvidas com a visão do cliente final.

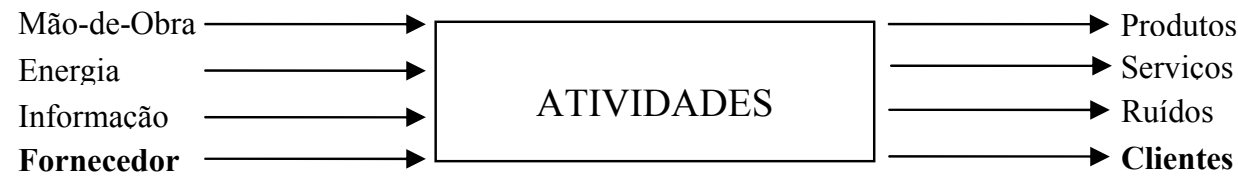

Figura 04: Visão esquemática de um processo. Fonte: ROTONDARO, 1997.

Segundo Morris e Brandon (1994), os processos podem ser alterados para o progresso da empresa considerando-se os seguintes fatores: qualidade, custo e eficiência operacional da empresa, serviço e resposta ao cliente e vantagem competitiva.

Neste sentido, Hammer e Champy (1994) afirmam que as empresas precisam organizar os seus trabalhos através de processos considerando-se três forças que as impelem atualmente: clientes, concorrência e mudança.

Já Porter (1992) indica que cinco forças determinam a dinâmica da competição em uma indústria: a entrada de novos concorrentes, a ameaça de substitutos, o poder de 
barganha dos clientes, o poder de barganha dos fornecedores e a rivalidade entre os concorrentes atuais.

Tirar o foco da especialização e centrar esforços nas ações de generalistas que consigam criar conexões mais claras entre as forças de mercado e as das áreas das empresas amplia as fronteiras da empresa, abre caminho para planejamentos mais aprimorados e ao mesmo tempo mais flexíveis, melhorando a percepção dos nichos de mercados mais interessantes (RENTES et al., 1995).

Em relação à capacidade de geração de valor para o cliente, os processos podem ser primários, quando incluem as atividades que geram valor para o cliente, ou de suporte, que são os conjuntos de atividades que garantem o apoio necessário ao funcionamento adequado dos processos primários (MARTIN, 1996). É importante notar que os processos primários são os de negócios, e que os processos organizacionais e os gerenciais, de acordo com essa definição, são processos de suporte (GONÇALVES, 2000a).

Um processo de negócio é um fenômeno que ocorre dentro das empresas. Ele possui um conjunto de atividades, associadas às informações que manipula utilizando os recursos e a organização da empresa. Forma uma unidade coesa e deve ser focalizado em um tipo de negócio, que normalmente está direcionado a um determinado mercado/cliente, com fornecedores bem definidos (ROZENFELD, 1996).

Nessas condições um processo de negócio constitui a manifestação do que os atores organizacionais (os empregados de companhia, departamento organizacional, clientes, provedores etc) fazem para alcançar os objetivos empresariais (KAVAKLI e LOUCOPOULOS, 1999).

Pelos processos de negócio, podem-se materializar as políticas gerenciais, os fluxos de documentos e informações, os procedimentos operacionais e os processos de manufatura (BREMER e LENZA, 2000).

Os processos de negócio são ligados à essência do funcionamento da organização (DREYFUSS, 1996 apud GONÇALVES, 2000a) sendo a interfuncionalidade uma sua característica importante.

Embora alguns processos sejam inteiramente realizados dentro de uma unidade funcional, a maioria dos processos importantes das empresas (especialmente os processos de negócios) atravessa as fronteiras das áreas funcionais. Por isso mesmo, são conhecidos como processos transversais, transorganizacionais (cross-organizational), interfuncionais ou interdepartamentais. Também são conhecidos como processos "horizontais", já que se desenvolvem ortogonalmente à 
estrutura "vertical" típica das organizações estruturadas funcionalmente. Enquanto os times verticais correspondem aos componentes funcionais, geográficos e de produtos da empresa, como é o caso da equipe de vendas, os times horizontais correspondem às pessoas que trabalham nos processos transorganizacionais (GONÇALVES, 2000a, p.12).

Como exemplo de processos de negócios que ocorrem em uma empresa, pode-se citar uma classificação proposta pela American Productivity \& Quality Center (APQC, 2002). Ela é composta por treze Processos de Negócios divididos em dois grupos: processos operacionais e processos de gerenciamento e suporte, conforme Figura 05 (GOULART, 2000).

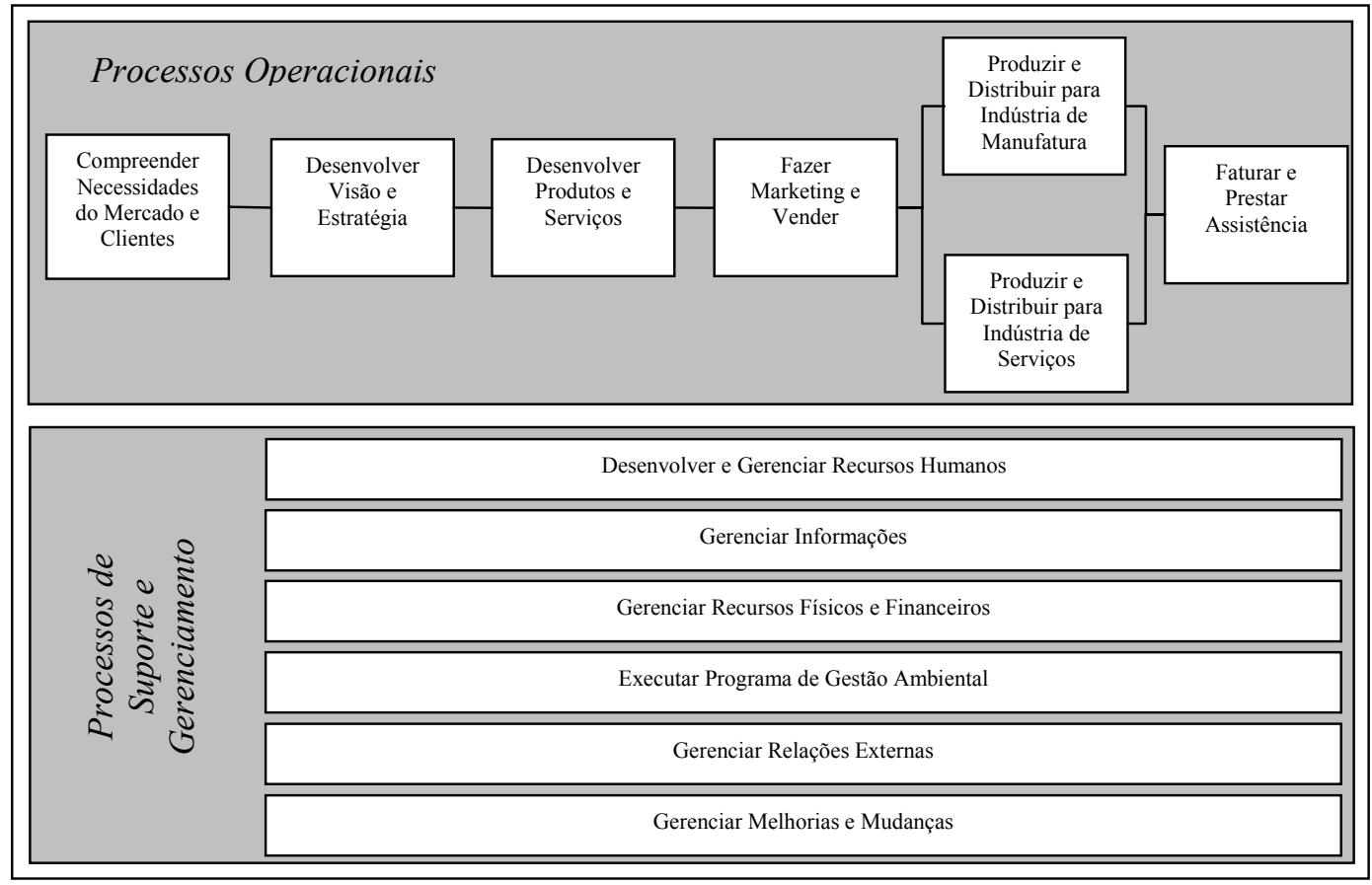

Figura 05: Framework de classificação de processos de negócio Fonte: APQC, 2002

Davenport (1994) aborda uma série típica de processos amplos para uma empresa de manufatura conforme a Tabela 02.

Tabela 02 - Processos típicos em empresas de fabricação.

\begin{tabular}{|c|c|}
\hline Operacional & Gerenciamento \\
\hline 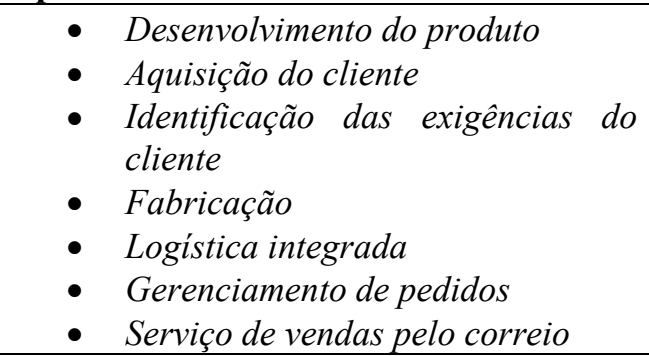 & $\begin{array}{l}\text { - Monitoramento do desempenho } \\
\text { - Gerenciamento das informações } \\
\text { - Gerenciamento das avaliações } \\
\text { - Gerenciamento dos recursos humanos } \\
\text { - Planejamento e alocação dos recursos }\end{array}$ \\
\hline
\end{tabular}
Adaptado: DAVENPORT, 1994. 
São três ou quatro os processos essenciais para a obtenção dos produtos ou serviços que são oferecidos aos clientes da empresa, sendo tipicamente processos de agregação de valor, e seu bom desempenho é crítico para o resultado da empresa (GONÇALVES, 2000b). Nesta inserção, Pires e Musetti (2000) destacam a importância estratégica e crescente de as indústrias conduzirem, de forma integrada e interdependente, o tratamento de três processos básicos: vender, produzir e atender ao cliente.

Em conformidade com os conceitos abordados, estabelecida a rede, ela deve ser operacionalizada segundo seu ciclo de vida e seus processos de negócio, englobando-se o processo de negócio Produzir, responsável por planejar e adquirir os recursos necessários a fim de converter insumos em produtos.

\subsection{O Planejamento e Controle da Produção (PCP) na manufatura distribuída}

O termo Planejamento e Controle da Produção pode ser definido como um conjunto de atividades gerenciais a serem implantadas para se concretizar a produção de um produto (PIRES, 1995).

Para Vollman et al. (1997), um sistema de PCP fornece informações para um gerenciamento eficiente do fluxo de materiais, uma utilização eficaz de recursos, uma coordenação interna das atividades com fornecedores e uma comunicação com os clientes sobre os requisitos de mercado.

Conforme Martins (1993, p.52), após a definição de quais produtos os consumidores estão demandando ou demandarão, o PCP compila todas as informações necessárias para cumprir os prazos de entrega, procurando fazê-lo de forma a manter a produtividade do sistema de manufatura. Neste sentido, o PCP deve responder a cinco importantes perguntas: o que será manufaturado, quanto será manufaturado, quando será manufaturado, como será manufaturado e onde será manufaturado.

A finalidade do PCP é aumentar a eficiência e eficácia do processo produtivo das empresas e da rede, transformando informações de vários setores em ordens de produção e ordens de compra - para tanto, deve exercer funções de planejamento e controle de forma a satisfazer os consumidores com produtos e serviços, e os acionistas com lucros.

Para atender à dupla finalidade, eficiência e eficácia, o PCP estabelece antecipadamente o que as empresas deverão produzir, o que deverá dispor de matériasprimas e materiais, de pessoas, de máquinas e equipamentos, estoques, para então 
monitorar e controlar o desempenho da produção em relação ao que foi planejado, corrigindo eventuais desvios ou erros que possam surgir.

Para Zaccarelli (1979, p.1) "a programação e controle da produção consiste essencialmente em um conjunto de funções inter-relacionadas que objetivam comandar o processo produtivo e coordená-lo com os demais setores administrativos da empresa".

O PCP trata de atividades altamente interdependentes e que sempre requerem uma abordagem sistêmica em sua execução. As atividades principais e mais comuns encontradas do PCP na literatura e na prática usual das empresas, conforme Pires (2001), são:

- Carteira de pedidos e previsão de vendas (forecasting)- O planejamento da produção praticamente se inicia com dados que estipulam quais e quantos produtos devem ser produzidos e quando eles devem estar concluídos.

- Planejamento agregado (Agregated Planning/Production Planning) Geralmente consiste no estabelecimento dos níveis gerais de produção, estoques e capacidades para um período de médio e longo prazo no contexto da empresa, devendo, portanto estar intimamente integrado com o planejamento financeiro e estratégico da empresa.

- Programa mestre da produção (Master Production Schedule) - É um referencial básico para a produção, que estabelece quando e em que quantidade cada produto deverá ser produzido em um certo horizonte de planejamento, pois trabalha com informações desagregadas.

- Planejamento das necessidades de materiais (Material Requirements Planning) - É a etapa na qual se definem as chamadas necessidades líquidas para cada produto e/ou componente a ser produzido. Isso geralmente é feito com base nas necessidades brutas advindas da lista de materiais, pelo que foi determinado no programa-mestre e pelas informações providenciadas pelo controle dos estoques.

- Programação da produção (Production Scheduling) - Geralmente trata da definição dos prazos para que sejam providenciados os itens já definidos como "fabricados" e como "comprados". No caso dos itens fabricados, geralmente há necessidade da definição prévia dos roteiros produtivos 
(planejamento dos processos) e do conhecimento da capacidade no período em questão dos recursos produtivos a serem utilizados.

- Planejamento e controle da capacidade (Capacity, Planning and Control)

- O planejamento procura estipular, por meio de um parâmetro adequado, quais devem ser os níveis de produção (saídas) máximos que os recursos produtivos devem ter num certo horizonte de tempo. Já o controle da capacidade cuida das providências para que a capacidade planejada seja realizada e colhe informações que serão utilizadas por outras atividades do PCP.

- Controle da produção (Shop Floor Control) - Consiste no acompanhamento e tomada de decisões durante a etapa de produção, objetivando o cumprimento dos prazos programados. Em geral, também providencia a coleta de dados para o sistema de custeio e de controle de estoques da empresa.

- Controle dos estoques (Inventory Control) - Consiste geralmente no conhecimento e controle dos níveis dos inventários diretamente ligados à atividade produtiva, de tal forma que eles estejam dentro dos níveis planejados e das diretrizes da empresa.

Pires (2001) relaciona algumas implicações no PCP em virtude da Gestão da Cadeia de Suprimentos, dentre as quais podem-se destacar as seguintes:

- para a Gestão da Demanda o grande desafio é administrar de forma integrada a demanda na cadeia produtiva;

- no Planejamento Agregado, o modelo de negócios baseado em unidades de negócios virtual e a relação de parceria com clientes e fornecedores têm proporcionado uma racionalização e um melhor dimensionamento e conhecimento das capacidades e dos recursos produtivos;

- quanto ao Programa Mestre de Produção a relação de parcerias com clientes e fornecedores também tem proporcionado a implementação de uma infraestrutura de informação que viabiliza a elaboração de programas mais confiáveis, consensuais e exeqüíveis. 
A Figura 06 ilustra essas atividades e faz também uma classificação delas em três níveis tradicionais de execução: planejamento, programação e controle.

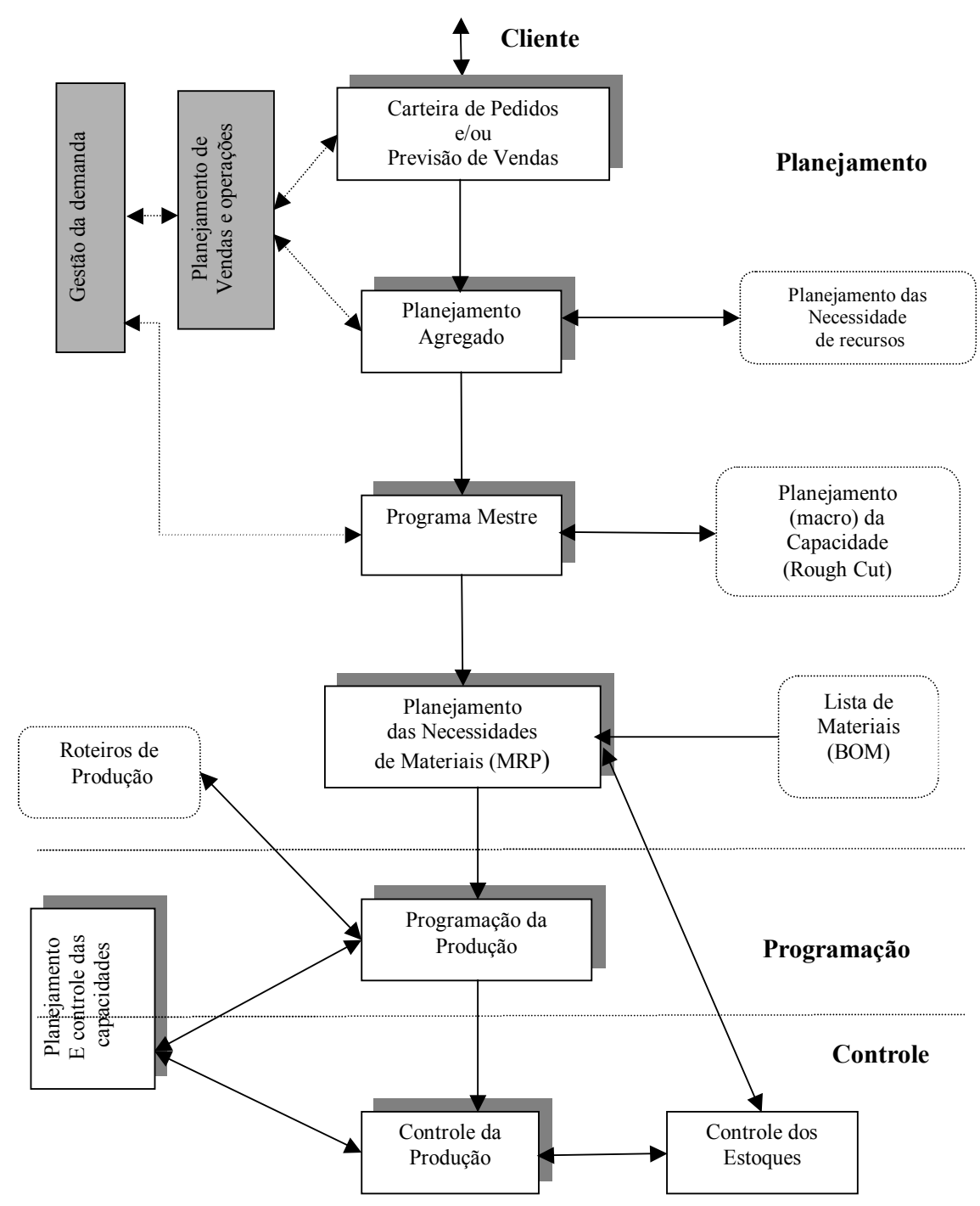

Figura 06: Atividades tradicionais de PCP. Fonte: PIRES, 1994.

Contador e Contador (1997) dividem as atividades do PCP em hierarquias horizontais, de forma que a fase posterior será iniciada após a implementação das decisões tomadas na fase anterior, como visto na Tabela 03 . 
Tabela 03 - Processo de decisão no planejamento da produção.

\begin{tabular}{c|l|l|l}
\hline HORIZONTE & \multicolumn{1}{|c|}{ ENTRADAS } & FUNÇÕES DO PCP & \multicolumn{1}{c}{ SAÍDAS } \\
\hline Longo Prazo & $\begin{array}{l}\text { Pesquisas de mercado, } \\
\text { Previsões de longo prazo. }\end{array}$ & $\begin{array}{l}\text { Planejamento de } \\
\text { recursos }\end{array}$ & $\begin{array}{l}\text { Linha de produtos, Processos } \\
\text { de fabricação, Política de } \\
\text { atendimento ao cliente. }\end{array}$ \\
\hline Médio Prazo & $\begin{array}{l}\text { Previsões de demanda de } \\
\text { médio prazo, Planos de } \\
\text { emprego da mão-de-obra. }\end{array}$ & Plano de produção & $\begin{array}{l}\text { Necessidade de materiais, } \\
\text { Planos de estocagem, Planos } \\
\text { de entrega, Níveis de força } \\
\text { de trabalho. }\end{array}$ \\
\hline Curto Prazo & $\begin{array}{l}\text { Prazos de entrega, } \\
\text { Prioridades de } \\
\text { atendimento. }\end{array}$ & $\begin{array}{l}\text { Programação da } \\
\text { produção }\end{array}$ & $\begin{array}{l}\text { Ordens de fabricação, } \\
\text { Tamanho do lote, Utilização } \\
\text { de horas extras, Reserva de } \\
\text { material. }\end{array}$ \\
\hline Prazo & $\begin{array}{l}\text { Ordem de fabricação, } \\
\text { Critérios de } \\
\text { seqüenciamento. }\end{array}$ & Liderança da produção & $\begin{array}{l}\text { Seqüência de tarefas, } \\
\text { Requisição de recursos, } \\
\text { Designação de tarefas, Coleta } \\
\text { de dados para controle. }\end{array}$ \\
\hline
\end{tabular}

Adaptado: CONTADOR e CONTADOR,1997

O planejamento da produção determina com que taxa os materiais entram na cadeia operativa e administra seu progresso, afetando a rapidez e a pontualidade proporcionada aos clientes, e demonstra ser um sistema com habilidade para atrair clientes e fortalecer além de intensificar a lealdade deles (De TONI e MENEGHETTI, 2000).

O "processo" tem um conceito fundamental no projeto dos meios pelos quais uma empresa pretende produzir e entregar seus produtos e serviços aos seus clientes (GONÇALVES, 2000a). Como os processos na área fabril são fáceis de observar, tanto nos períodos de bom funcionamento como na ocorrência de problemas, eles podem ter várias de suas dimensões medidas (DAVENPORT, 1994) e condiciona as atividades de Planejamento e Controle da Produção a serem vistas não em termos de função, departamentos ou produtos, mas como elementos integrantes de processos.

Os processos de negócios são vitais para que as empresas promovam uma melhoria da manufatura em diferentes níveis de detalhamento, devendo ser mapeados para que sirvam de referência para diferentes abordagens, apoiando a obtenção sistemática de uma visão holística da empresa (ROZENFELD, 1996).

\subsection{Considerações finais}

Em um ambiente de manufatura distribuída, o planejamento da produção coordena os pedidos e designa os diferentes recursos em uma produção cooperativa de várias empresas (De TONI e MENEGHETTI, 2000). Ou seja, o planejamento da produção desempenha um papel-chave em um ambiente de manufatura distribuída (MEZGÁR et al. 2000). 
De Toni e Meneghetti (2000) sugerem que o ponto crucial em uma rede entre empresas é a sua coordenação, que é realizada através do planejamento da produção, principalmente quando o foco dessa rede é a produção. É reconhecido que o sistema de planejamento e controle tem significantes implicações para a prosperidade das operações de qualquer organização industrial, tanto internamente quanto ao longo da cadeia de suprimentos (KEHOE e BOUGHTON, 2001).

Como se depreende, o sistema de PCP possui importância de primeira grandeza dentro da empresa industrial como da rede. Além disso, há uma crescente necessidade de as organizações industriais explorarem mecanismos alternativos para a administração de sua rede de operações (KEHOE e BOUGHTON, 2001), que justifica o interesse na modelagem do PCP, de modo que este PCP se converta em um sistema que: otimiza o uso dos recursos produtivos, proporciona fluidez à produção, reduza dificuldades e auxilie a manter a eficiência em níveis elevados. 


\section{CARACTERIZAÇÃO DO SETOR DA CONSTRUÇÃO CIVIL E O SEU RESPECTIVO PROCESSO DE PLANEJAMENTO E CONTROLE DA PRODUÇÃO}

\subsection{Introdução}

Este capítulo irá apresentar o ambiente conceitual sobre o qual o Estudo de Caso foi desenvolvido. No Brasil, especialmente na Construção Civil, as grandes empresas já vêm realizando consórcios para a execução de grandes obras, através da tecnologia de gestão baseada no associativismo e cooperação entre as empresas (CASAROTTO, 2002).

A indústria da construção é uma efetiva indústria de transformação, que se utiliza de um sistema produtivo peculiar (CASAROTTO, 2002). A análise da peculiaridade desse sistema produtivo tem por intento definir e compreender o escopo e contornos de atuação do Planejamento e Controle da Produção no setor da construção civil.

\subsection{Setor da Construção Civil}

O setor industrial da Construção Civil, no Brasil, vive a busca da eficiência produtiva, da qualidade de seus produtos e de uma melhor adaptação às mudanças que ocorrem em seus segmentos de mercado. Diante das profundas mudanças na conjuntura setorial, as empresas construtoras vêm sendo pressionadas a alterarem seus processos de produção no sentido de reduzir custos e adequar a realidade dos produtos ofertados às condições de mercado. A necessidade de ganhar eficiência nos processos, nos rearranjos nas estratégias frente ao mercado desencadeou processos de alterações organizacionais e tecnológicas. (MELHADO, 2001)

Nesse sentido, a preocupação das empresas construtoras em promover melhorias de qualidade em todo o processo de projeto e produção, em um ambiente cada vez mais globalizado e competitivo, implica em adoção de procedimentos de planejamento e programação que gerem informações para atender a necessidades da empresa e seus 
empreendimentos $^{15}$, permitindo soluções sempre mais eficientes (SANTOS e MOCCELLIN, 2000).

Esse ponto é reforçado quando o mito da desqualificação do profissional já não é mais aceitável para justificar índices de produtividade - segundo McKinsey (1999) apud Casarotto (2002) - entre 20 e 50\% de países desenvolvidos, observando-se que esta baixa produtividade é resultado de deficiências no planejamento e no gerenciamento dos projetos das empresas do setor (CASAROTTO, 2002).

Neste âmbito, soluções tecnológicas mais simples baseadas na aplicação de teorias e princípios básicos de gestão passam a apresentar uma nova tendência de melhoria do processo produtivo da construção (MACHADO, 2003). Leva-se em consideração que a gestão, segundo Ohnuma (2003), consiste numa rotina gerencial que engloba atividades de planejamento, de controle e de ação de melhoria para as quais devem existir responsabilidades claramente definidas para todos os envolvidos em um determinado processo.

A gestão, segundo Machado (2003), está vinculada ao projeto, a operações e ao melhoramento dos sistemas de produção de uma organização que gera bens e/ou serviços. Ele preconiza-se a necessidade de identificação do sistema de produção, para poder determinar estruturas típicas e apresentar diretrizes para gerenciá-lo, desde a atividade de gestão estratégica da produção, passando pelo desenvolvimento de projetos até o PCP (MACHADO, 2003).

Hayes e Wheelwright (1984) apud Slack et al. (1997) propõem uma classificação do sistema de produção conhecida como Matriz de Produto versus Processo, no qual a indústria da construção caracteriza-se por possuir sistemas produtivos por projetos. Sistemas dessa natureza são peculiares pela geração de elevada variedade de produtos finais e pelo reduzido volume de produção (a rigor, ocorre a produção de produtos ou lotes de produtos únicos) (SLACK et al., 1997).

\footnotetext{
15 Em geral são quatro as principais fases de um empreendimento: (1) A montagem - na qual são realizados os estudos preliminares e o programa do empreendimento, sendo o principal agente o empreendedor; (2) O desenvolvimento do projeto e escolha das empresas construtoras - a partir da contratação das empresas dá-se início à preparação da execução das obras, que inclui as atividades de planejamento da execução das obras, tendo como agente central a equipe projetista; (3) A organização e a execução dos serviços (as empresas construtoras constituem o agente principal), onde se destacam as fases de preparação da execução de obras e a gestão da sua execução (técnica, administrativa e financeira); (4) E, por fim, a entrega da obra e a gestão do empreendimento (uso, operação e manutenção) (agente principal o empreendedor). (MELHADO, 2001)
} 
Um sistema produtivo por projeto pode ser caracterizado genericamente pelos seguintes aspectos (MACHADO, 2003):

- objetivo: Envolve um resultado final definido em termos de custo, qualidade e prazos dos resultados das atividades do projeto;

- complexidade: Muitas tarefas diferentes são necessárias para atingir os objetivos de um projeto;

- unicidade: Um projeto é usualmente único, não um empreendimento repetitivo;

- incerteza: Como os projetos são únicos - nunca foram executados antes carregam um elemento de risco;

- natureza temporária e ciclo de vida: como os projetos possuem início e fim definidos, requerem um processo de mobilização temporária e desmobilização de recursos à medida que avança sua evolução.

A Indústria da Construção já se diferencia das demais indústrias, juntamente com a indústria naval e com a fabricação de equipamentos pesados, por seu produto final ser de posição fixa, geralmente único, com um ciclo de vida longo e inconstância de utilização de recursos em habilidades e quantidades. Os sistemas para a produção com posição fixa se caracteriza por trabalharem sob encomenda ${ }^{16}$, com projeto específico, baixo volume de produção e conseqüente baixa padronização do produto. (CASAROTTO, 2002)

\subsection{Planejamento e Controle da Produção e Construção Civil}

Convencionalmente, a administração de operações no setor da construção está tradicionalmente baseada no Modelo das Conversões (input-conversão-output) (SLACK et al., 1997). Através dessa concepção, o gerenciamento deve realizar a divisão do projeto (processo) em partes menores (subprocessos) a serem administradas isoladamente na busca de eficiências individuais. Entretanto, um maior potencial de obtenção de melhoria é obtido por um balanceamento entre os esforços de conversões, referente às atividades/operações que efetivamente promovem a agregação de valor ao produto acabado, e fluxos que representam toda a atividade existente no sistema

\footnotetext{
16 Ou, segundo Wemmerlöv (1986), Marucheck e McClelland (1986) apud Pires (1995), podem-se classificar os sistemas produtivos, segundo quatro tipos básicos, a partir de sua interação com os clientes, ou seja, conforme o nível de interferência que o comprador pode ter no produto final: (1) Produção para estoque - MTS, (2) Montagem sob encomenda - ATO, (3) Produção sob encomenda - MTO, (4) Engenharia sob encomenda-ETO.
} 
produtivo que não agrega valor diretamente ao produto acabado (atividades auxiliares) (MACHADO, 2003).

Dentro desse novo paradigma de gerenciamento da construção, por meio do balanceamento de ações entre fluxos de processos e de operações, diversas abordagens vêm sendo utilizadas (a exemplo da Construção Enxuta ${ }^{17}$ ). De uma maneira geral, essas abordagens envolvem: gestão sobre os projetos; pesquisa e desenvolvimento de novas tecnologias; industrialização ou pré-fabricação; gestão sobre a cadeia produtiva; organização do trabalho e produtividade; e planejamento e controle da produção. No que tange ao planejamento e controle da produção, existe uma lacuna na melhoria das informações que alimentam os planos de produção, de forma que decisões referentes a questões operacionais do planejamento ficam negligenciadas e relegadas ao campo da informalidade. (MACHADO, 2003)

Assumpção (1996) apud Santos e Moccellin (2000), aborda três níveis de tomada de decisão, que direcionados para o setor da construção podem ser apresentados em três hierarquias de decisões, promovendo um fluxo de informações de forma a propor um sistema de planejamento, como ilustra a Figura 07.

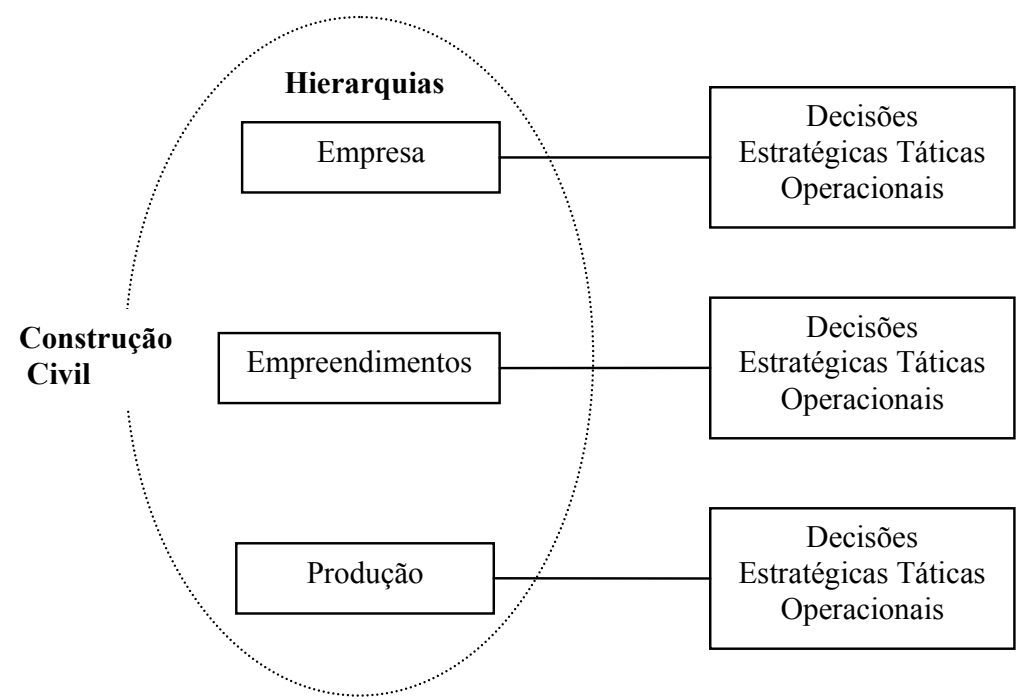

Figura 07: Conjunto de decisões tomadas em três hierarquias. Fonte: SANTOS e MOCCELLIN, 2000.

\footnotetext{
${ }^{17} \mathrm{O}$ setor da Construção Civil tem demonstrado uma busca pela eficiência produtiva, que pode ser observado através de pesquisas no conceito de Produção Enxuta aplicado ao setor, que recebe a terminologia de Construção Enxuta, e, segundo Santos e Moccellin (2000), pretende promover uma renovação na indústria de construção, através do desenvolvimento de novos modelos de gestão da produção na cadeia produtiva da construção civil, além de buscar a introdução de novos princípios e métodos para o projeto de produtos e processos. Isso, porque os princípios de Produção Enxuta objetivam desenvolver vários níveis de planejamento e controle da produção pelo estudo dos fluxos físicos e de informações envolvidas (OHNUMA, 2003).
} 
A prática do planejamento no setor da construção civil, incluindo os planejamentos estratégicos, táticos e operacionais para os níveis empresa, empreendimentos e produção, ainda requer mais conhecimento de conceitos, das técnicas, dos modelos de planejamento, de programação e de controle já desenvolvidos. Por outro lado, "o setor carece de propostas que consigam lidar com questões de incerteza, comprometimento, transparência e formalização do processo de planejamento". (REICHMANN et al., 1998 apud SANTOS e MOCCELLIN, 2000).

As decisões de caráter estratégico/tático na hierarquia da produção, conforme Assumpção (1996) apud Santos e Moccellin (2000), são tomadas pensando na definição dos meios e procedimentos para a execução do empreendimento que envolvem definições sobre as datas das principais etapas da obra, definições de seqüência trajetória de execução e estratégias para o suprimento de mão-de-obra para a produção, de materiais e de equipamentos especiais. Muitas informações que alimentarão esse nível são geradas pela programação de obras, que permite a formulação de previsões de tempos de execução, custos e recursos, e, conseqüentemente, permite a racionalização do processo de produção.

Segundo Machado (2003) e Ohnuma (2003), as decisões sobre o planejamento da produção podem se divididas em três grandes áreas ou níveis: decisões estratégicas (de longo prazo), decisões táticas (de médio prazo) e decisões de planejamento operacional e controle (de curto prazo).

Destaca-se, conforme Martucci (1990) apud Santos e Moccellin (2000), que o planejamento da produção compreende etapas altamente integradas entre si: elaboração da política de produção; estudo tecnológico do sistema construtivo; definição do fluxo tecnológico; definição e caracterização dos processos de trabalho; definição da trajetória de obra; elaboração da programação de obras; e elaboração de orçamentos.

Nesse sentido, em um primeiro nível é desenvolvido o plano inicial, definindo-se o cronograma geral da obra, tratando-se de questões relativas ao desembolso financeiro, ao seqüenciamento de atividades e à previsão de recursos necessários à produção, direcionando-se o enfoque aos objetivos globais e restrições do projeto como um todo. Em um segundo nível, realiza-se uma previsão mais detalhada, um horizonte de tempo que varia de duas a seis semanas, conforme a estabilidade existente no processo, a fim de especificar os meios para se atingir os objetivos do plano de longo prazo. Em um terceiro nível, faz-se um planejamento de compromissos das atividades que devem ser realizadas no curto prazo, usualmente de um (1) a quinze (15) dias de trabalho, 
considerando-se os aspectos relacionados aos meios de produção, equipamentos, layout do canteiro, alocação dos recursos humanos, seqüência de trabalho, programação do projeto e orçamento, de forma a detalhar as necessidades de recursos para a execução das atividades e das tarefas de cada dia, envolvendo a definição sobre o trabalho físico a ser realizado no dia seguinte (equivale a ordem de produção). (MACHADO, 2003)

Machado (2003) aborda um modelo de planejamento hierárquico para o sistema produtivo da construção, que deve passar a incluir planos destinados especialmente a horizontes temporais menores, em função da incerteza existente no ambiente que envolve o sistema produtivo da construção (Figura 08).

\section{A hierarquia do Planejamento, Programação e Controle da produção para o sistema produtivo da construção.}

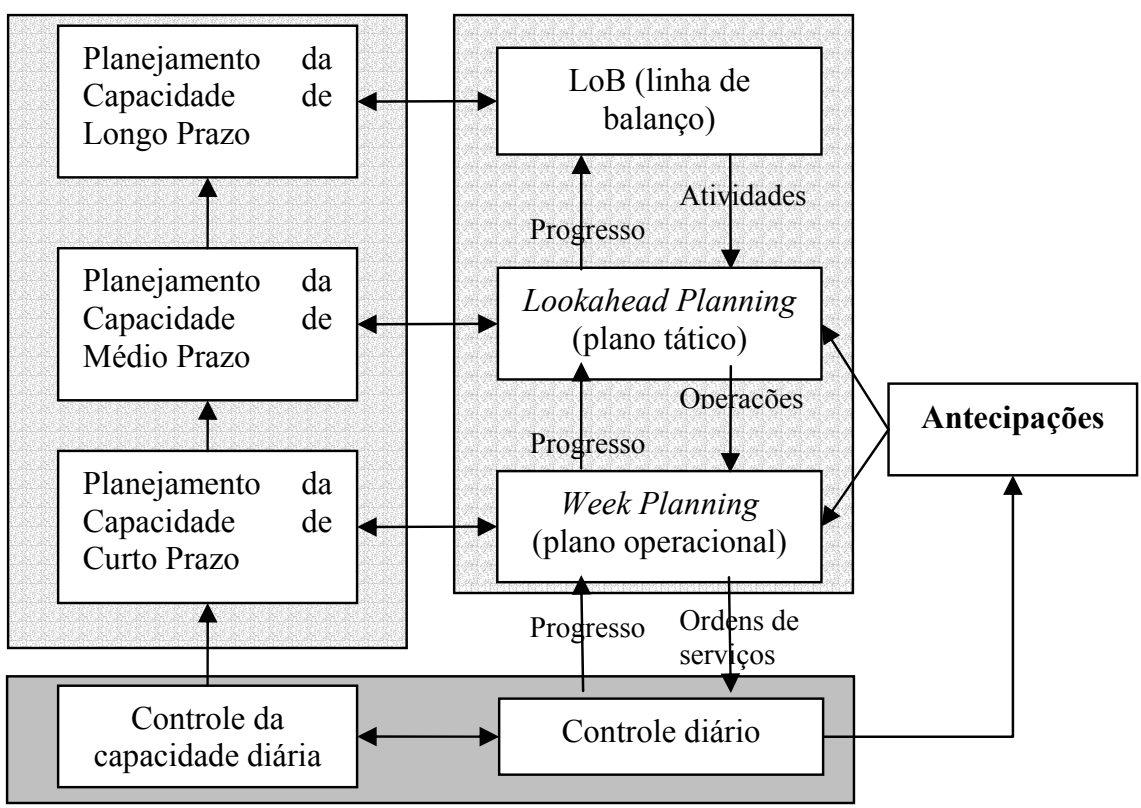

Figura 08 - O modelo de planejamento hierárquico da produção para sistemas produtivos da construção. Adaptado: MACHADO, 2003.

De acordo com o modelo da Figura 08, o processo de planejamento deve ser iniciado com as decisões de longo prazo. É pertinente considerar no planejamento da produção, conforme Koskela (1999) apud Machado (2003), a gestão sobre ao menos sete fluxos básicos de insumos: projeto; componentes e materiais; trabalhadores; equipamento; local de trabalho; serviços inter-relacionados e condições externas. Auxiliando no processo de planejamento encontram-se as técnicas de programação composta por modelos baseados em redes lógicas como o PERT (Program Evalution and Review Technique) ou por modelos feitos a partir de análise de operações como o 
CYCLONE (Cyclic Operations Network System) ou o método Linha de Balanço (LOB) (SANTOS e MOCCELLIN, 2000).

A tendência dos planos gerados no nível de longo prazo é a de considerar objetivos globais e restrições tratando do projeto como um todo. Como restrições genéricas de capacidade, o planejamento deve preocupar-se com questões ligadas às orientações estratégicas como o prazo de execução do projeto, características de qualidade e custos. (BALLARD, 2000 apud MACHADO, 2003)

As informações sobre o que deve ser executado aparecem de forma bastante agregada, tratando de serviços, e normalmente correspondem aos elementos indicados no orçamento da obra. O horizonte de planejamento é definido pelo prazo total de execução do projeto, e o período de tempo considerado é comumente um mês. (MACHADO, 2003)

A integração com o médio prazo efetiva-se através da desagregação dos serviços em atividades e operações que devem poder ser incluídas em períodos de tempo semanais no plano tático. Por meio de redes operacionais, geradas previamente para as atividades comuns a todos canteiros de obras, promove-se a desagregação necessária dos serviços considerados de forma agregada no longo prazo. (MACHADO, 2003)

O planejamento de médio prazo através do Lookahead Planning (instrumento viabilizador do planejamento e controle do fluxo de trabalho) apresenta o mérito de proporcionar a ligação entre as decisões estratégicas tomadas no longo prazo, com a necessidade de definição de ações ao nível operacional, em bases que vão freqüentemente do dia de trabalho até a quinzena. É definido em função das características de projeto, da confiabilidade do sistema de planejamento e de lead times de aquisição de informações, materiais, mão-de-obra e equipamentos. Comumente, o horizonte de planejamento considerado no Lookahead varia de 3 a 12 semanas, dependendo da confiabilidade do sistema produtivo planejado. (MACHADO, 2003)

O planejamento da capacidade de produção de médio prazo envolve a conciliação entre a quantidade de horas-homem disponíveis e a carga (em termos de horas de trabalho) demandada nas operações programadas, na janela de tempo da programação Lookahead Planning. A ligação do plano tático com o plano operacional dá-se pela inclusão de operações programadas para serem executadas no planejamento semanal (Week Planning), tendo a importância fundamental de gerar ações no canteiro por meio das ordens de serviços. (MACHADO, 2003) 
O planejamento da capacidade de produção para o curto prazo baseia-se no nivelamento da quantidade de horas-homem disponíveis para realizar as atividades alocadas, para a execução, dentro da semana de trabalho. O curtíssimo prazo é controlado diariamente pela avaliação do fluxo de produção ao longo dos turnos do dia de trabalho. Nesse horizonte de planejamento, as ações gerenciais envolvem coordenação e direção. $\mathrm{O}$ controle da capacidade inclui ações rápidas destinadas a reforçar momentaneamente a capacidade de trabalho de uma atividade, por meio da realocação de operários, e através dos esforços proativos do controle da produção descobrem-se eventuais causas de desvios que só podem ser identificadas no dia-a-dia do canteiro. O conhecimento adquirido em projetos anteriores, em um primeiro momento, juntamente com esses desvios, deve ser analisado e incluído nas Antecipações que alimentam o Lookahead e o Week Planning gerando um processo de melhoria contínua através de um planejamento de antecipações em relação à ocorrência de eventos indesejáveis. (MACHADO, 2003)

Chua e Shen (2001) apud Machado (2003) consideram o gerenciamento de restrições (análogo à sistematização de antecipações ${ }^{18}$ ) o assunto principal do PCP durante o curso de um projeto, que exerce um papel importante para determinar se o processo está pronto para ser executado Daí, a importância de destacar a sistematização de antecipações, procurando agir sobre o que pode influenciar negativamente a produtividade através de ações de antecipação incluídas no planejamento. Nem todos os tipos de restrições necessitam ser incluídas no planejamento; algumas devem ser resolvidas no nível da emissão de ordens de serviços.

Um planejamento adequado é aquele que reflete com precisão a seqüência de trabalhos que efetivamente podem ser realizados nos próximos períodos, levando-se em consideração as restrições de insumos e técnicas de execução a que a obra se vê submetida a cada etapa (CONTE, 1997). Podem-se antecipar os resultados esperados dos trabalhos a serem realizados, mediante um apropriado conjunto de documentos, intitulado planejamento executivo, que compreende (CONTE, 1997):

- Especificação da obra a ser executada: memoriais descritivos, especificações técnicas, normas técnicas de referência, métodos construtivos a serem utilizados e projetos;

\footnotetext{
${ }^{18}$ Vale mencionar que Machado (2003) apresenta e sistematiza os fatores que afetam a produtividade e como podem ser convertidos em ações gerenciais de antecipação no planejamento da produção.
} 
- Custos: valores previstos para a execução dos serviços e diretrizes de negociação com fornecedores;

- Prazos: programação de execução dos serviços

- Logística de insumos: arranjo físico de canteiro, equipamentos e ferramentas de apoio, procedimentos para recebimento, movimentação, armazenagem e disponibilizarão de insumos;

- Logística de informação: equipe administrativa de apoio, organograma, definição de funções, procedimentos para acompanhamento do andamento dos trabalhos realizados e avaliação do desempenho alcançado.

\subsection{Considerações finais}

Portanto, diante das apreciações consideradas neste capítulo, a racionalização da construção civil possui dependência do desempenho global de um complexo sistema de elementos interdependentes, no qual, conforme Kehl (1997), se inserem a concepção e a forma de apresentação do projeto, os recursos disponíveis, o nível profissional do pessoal empregado, o ritmo da construção, o arranjo físico do canteiro e, especialmente, a eficiência do planejamento, da execução e do controle físico-financeiro da obra. 


\section{MODELAGEM ORGANIZACIONAL}

\subsection{Introdução}

O capítulo tem por objetivo introduzir e discutir conceitos relacionados à Modelagem Organizacional, uma vez que, segundo Carpinetti (2000), ela pode ser usada para o entendimento de um processo por meio da criação de um "mapa do processo" que mostra graficamente o relacionamento entre seus elementos.

O tópico Modelagem Organizacional focaliza a metodologia Enterprise Knowledge Development (EKD), a qual apresenta uma forma sistemática de analisar, entender, desenvolver e documentar uma organização e seus componentes, com o objetivo de desenvolver um modelo conceitual de atividades do PCP em um ambiente de redes de cooperação produtiva assimétrica.

Por fim, fazem-se as considerações relevantes sobre a modelagem de obras de construção civil, formulando um lineamento de conceitos e apresentando um modelo de referência.

\subsection{Modelagem Organizacional ou Modelagem de Empresas}

Atualmente, as empresas precisam de sistemas ágeis a mudanças constantes do ambiente do negócio para garantir que os sistemas cumpram com sua finalidade. Os desenvolvedores devem possuir uma compreensão mais aprofundada sobre a organização, seus objetivos, metas e estratégias de mercado.

De nada adianta a melhor estratégia, a melhor organização e os melhores recursos se não houver uma boa compreensão do negócio, desenvolvimento de seus produtos, comercialização e produção (ROZENFELD, 1996).

Os modelos de empresas, com os seus respectivos submodelos provêem o tomador de decisão de uma representação mais uniforme da empresa, de uma melhor compreensão da empresa e de seus negócios, de suporte para o desenvolvimento de novas áreas da empresa, contribuindo para o monitoramento e controle de suas operações (VERNADAT, 1996). 
A utilização do conceito de processos fornece um conveniente nível de análise e, além disso, permite ter uma visão melhor do comportamento gerencial, mais integrada e abrangente, sendo também indispensável para possibilitar a análise adequada dos processos administrativos e gerenciais, tão importantes para o funcionamento dos processos essenciais da organização (GONÇALVES, 2000a).

Nesse sentido, as organizações devem apostar não só no desenvolvimento e implementação rápida e com qualidade dos sistemas, mas também, na modelação dos processos de negócios, de forma a construir um modelo que reflita as necessidades organizacionais. Esse modelo representa uma base de conhecimento importante que poderá, no futuro, permitir que eventuais modificações nos processos de negócios, por exemplo, a introdução de novas regras no processo ou novos agentes, sejam realizadas de forma expedita. (LOUSÃ et al., 2003)

Epilogando, segundo Vernadat (1996), os processos de negócios representam o fluxo de controle do que ocorre na empresa, materializam políticas de gerenciamento, fluxos de documentação, processos operacionais, processos de manufatura, processos administrativos e regulamentações. E a integração interempresarial é a concomitante integração dos processos de negócios de uma dada empresa aos processos de negócios de outra, ou mesmo o compartilhamento de partes dos processos de negócios por diferentes cooperações empresariais. Infere-se que a modelagem e a integração empresarial são obtidas através da modelagem e integração dos processos de negócios. (VERNADAT, 1996)

A maneira de se trabalhar orientada por processos de negócios é feita por meio da construção de um modelo dos processos de negócios da empresa, a partir do qual se constrói uma visão de aspectos comportamentais e organizacionais (BREMER e LENZA, 2000).

É neste sentido que a modelagem organizacional permite não só melhor entender requisitos organizacionais que interferirão nos sistemas, mas também identificar alternativas para os vários processos da organização.

O modelo organizacional é uma representação da estrutura, atividades, processos, informações, recursos, pessoal, comportamento, objetivos e restrições das empresas comerciais, governamentais ou de outra natureza, a fim de ajudar a compreender as complexas interações entre organizações e pessoas (ALENCAR, 1999). Cada organização tem sua missão, seus objetivos e seus processos próprios, e é 
importante condicionar a sistematização desses processos através de metodologias de modelagem organizacional.

Modelagem de empresas é uma atividade corporativa que produz modelos de recursos, de fluxos de informação e de operações dos negócios que ocorrem na empresa (HUHNS et al., 1992 apud MANCUSO e EDELWEISS, 2002). Segundo Bubenko et al. (2001), Modelagem Empresarial é um processo em que um modelo de empresa é integrado, negociado e criado, visando descrever um empreendimento específico de várias perspectivas diferentes.

Um dos principais objetivos buscados na construção da especificação de uma empresa, através da sua modelagem, é o de melhor entendê-la, com vistas a identificar problemas e procurar soluções que melhorem o seu desempenho organizacional, tal como aumentar a velocidade das tarefas, reduzir custos e otimizar a qualidade dos serviços (MANCUSO e EDELWEISS, 2002).

Um das vantagens da modelagem é o efeito nos participantes, projetando-se um melhor entendimento das partes essenciais do empreendimento, buscando-se soluções para problemas práticos ou chegando-se a um consenso sobre determinado assunto, o que torna o modelo uma efetiva ferramenta para melhorar tanto a comunicação como também o aprendizado organizacional (BUBENKO et al., 2001).

Ou seja, um modelo de boa qualidade é baseado na discussão explícita dos participantes e relacionamentos entre elementos de diferentes submodelos. O modelo fornece, de forma natural, uma possibilidade para os participantes entrarem em questões e fenômenos que são relacionados com sua parte do negócio e verem o impacto de suas decisões ou requisitos de todos os processos da organização. Os modelos proporcionam benefícios para a cultura e aprendizado organizacionais. Eles podem ser efetivamente usados para representar e discutir como projetar e melhorar processos organizacionais, e como desenvolver estratégias futuras. Entretanto, são limitados, uma vez que eles apenas apresentam percepções subjetivas de como as coisas são. (PÁDUA, 2001).

\subsection{Arquitetura de referencia para modelagem e integração empresarial}

Os métodos de modelagem a serem utilizados para representar as empresas precisam relacionar a estrutura das informações e dos processos com os negócios e objetivos organizacionais. Diversos métodos de modelagem de empresas têm sido propostos, porém, algumas técnicas de modelagem têm provado ser inválidas para 
suportar este tipo de desenvolvimento. A maioria dos métodos existentes representa apenas uma visão específica da empresa. (MANCUSO e EDELWEISS, 2002)

Nesses termos, algumas das mais representativas arquiteturas de referência serão mencionadas, de modo a se obter uma conceitualização límpida.

Vernadat (1996) aborda os frameworks, as arquiteturas e metodologias que vêm sendo propostas para modelagem e integração das empresas como arquiteturas de referência úteis à discussão e esclarecimento de vários aspectos da integração.

O termo "arquitetura" refere-se a um organizado conjunto de elementos com um claro relacionamento um com o outro, que juntos formam um arcabouço definido para sua finalidade. O termo "framework" refere-se a uma coleção de elementos colocados juntos segundo algum propósito. Pode-se referir a um framework para modelagem empresarial, definindo o escopo, conceitos e métodos necessários à modelagem de uma empresa de manufatura. Portanto, framework se apresenta como um termo mais geral que arquitetura, significando que diferentes arquiteturas podem ser propostas dentro de um dado framework. Metodologia é um conjunto de métodos, modelos e ferramentas a serem utilizadas de forma estruturada para solucionarem problemas. (VERNADAT, 1996)

As arquiteturas da referência são os paradigmas intelectuais que facilitam a análise, discussão e especificações exatas de uma dada área de discurso. Fornecem uma maneira de visualizar, compreender e abordar o assunto (VERNADAT, 1996).

As seguintes arquiteturas de referência são citadas como as mais representativas, embora seja a lista incompleta. A finalidade é mencionar arquiteturas de referencia representativas para o escopo de modelagem empresarial, atualmente disponível: ISO (International Standard Organization) work; CEN (Comitê Europeu para Padronização) ENV (European Prestandard) 40 003; ARIS (ARquitetura para Sistemas de Informação integrada); CIMOSA (Sistema Europeu de Arquitetura Aberta para Manufatura Integrada por Computador); PERA (Purdue Enterprise Reference Architecture) e EKD (Enterprise Knowledge Development).

\subsubsection{ISO, framework de modelagem empresarial}

O trabalho sobre ISO em modelagem e integração de empresas incide sobre o escopo do Technical Committee TC 184 (ISO TC 184), Sub-Committee 5 (SC5), Working Group 1 (WG1) em arquiteturas de sistemas, grupo este que se encontra em 
atividade desde 1986, sendo o responsável pelo trabalho em integração e automação industrial do ISO TC 184 (VERNADAT, 1996).

Um modelo referencial para padrões da produção do chão de fábrica foi documentado e editado em duas partes. A parte 1 descreve um modelo referencial para padronização e uma metodologia para identificação de requerimentos padrões para automatização industrial; A 2 aborda a aplicação do modelo referencial e da metodologia nas áreas em geral da automação industrial e na produção do chão de fábrica. (VERNADAT, 1996)

O modelo referencial ISO, descrito na parte 1, é estruturado segundo três submodelos:

1) um contexto para produção do chão de fábrica, que identifica as principais funções (finanças, sistema de ordem de vendas, MRP, engenharia/CAD, produção e estocagem) das distintas partes da manufatura e os principais fluxos de informações ao longo dela;

2) o modelo de produção do chão de fábrica (SFPM);

3) o modelo genérico de atividades (GAM), o qual descreve atividades e fluxos (materiais, informações e recursos) através das atividades.

\subsubsection{CEN ENV 40003}

O ENV 40003 foi preparado pelo Comitê Europeu para Padronização (CEN/CENELEC AMT/ WG-ARG Working Group on CIM Systems Architecture). Passou a ficar sob responsabilidade do CEN Technical Committee TC310 Working Group 1, sendo o objetivo deste grupo de trabalho o de assegurar que as exigências da indústria européia sejam encontradas, de forma que a máxima vantagem possa ser tirada da padronização para a modelagem empresarial e do uso do desenvolvimento ambiental que irá influenciar a organização industrial, gerenciamento e manufatura, a fim de melhorar a eficiência. (VERNADAT, 1996)

ENV 40003 é estruturado segundo três dimensões:

1) Dimensão genericity - O ENV 40003 define três níveis genericity: (1) o genérico, que define a base para a construção da modelagem segundo os componentes, obstáculos, regras, termos, serviços, funções e protocolos; (2) o nível parcial, que contém modelos parciais; (3) por fim o nível particular, que descreve a empresa segundo conhecimentos específicos utilizando-se para isso o nível genérico. 
2) Dimensão dos modelos - A ENV 40003 reconhece três tipos de modelos: (1) o modelo de requerimentos, que define as operações a serem realizadas na empresa, com terminologias, informações, recursos, requerimentos, responsabilidades e autoridades sem estar referenciando-se a opções e decisões de implementação; (2) o modelo de design, que especifica como as operações da empresa deverão ser realizadas; (3) o modelo de implementação, que descreve os significados e/ou regras a serem utilizadas na execução das operações empresariais definidas no modelo de requerimentos.

3) Dimensão das visões - Define a perspectiva ou ponto de vista a serem considerados para que a empresa atinja seus propósitos, concentrando em alguns aspectos e escondendo irrelevantes aspectos, a fim de reduzir a complexidade. A ENV 40003 define quatro visões: (1) a visão da função; (2) visão da informação; (3) visão do recurso; e (4) visão da organização.

\subsubsection{ARIS}

ARIS significa Arquitetura para Sistemas de Informação integrada. Foi desenvolvido pelo professor Scheer da Universidade de Saarbrücken, na Alemanha. Sua estrutura como um todo é bem similar ao CIMOSA (VERNADAT, 1996).

É estruturada segundo quatro visões e três níveis de modelagem. Os três níveis de modelagem são os mesmos do CIMOSA (VERNADAT, 1996):

1) definição de requerimentos - Para expressar as necessidades do negócio percebida pelo usuário;

2) especificação do design - Para construir um formal, conceitual e executável modelo do sistema da empresa (tempo é levado em conta);

3) descrição da implementação - Para documentar detalhes da implementação, recursos instalados, levando-se em conta sistemas não determinados.

As quatro visões são as seguintes:

1) A visão das funções - Usada para definir o modelo de função como uma hierarquia de funções, para então especificá-las em termos de estruturogramas e módulos de programa, e finalmente gerar o código dos programas;

2) A visão dos dados - Usada para definir modelo de dados semânticos (em termos de diagramas de entidade-relacionamento), e então traduzi-los em um 
esboço relacional antes de implementá-los em um sistema de banco de dados físicos;

3) A visão organizacional - Usada para definir a estrutura da empresa resumida por um organograma, a rede topológica e a rede física de implementação;

4) A visão controle - Que relaciona a arquitetura às três outras visões. É nela que podem ser reunidos os processos de negócios (também chamado de cadeia de atividade), e também implementados como sucessões lógicas de programas de execução.

ARIS é uma arquitetura aberta, uma vez que o sentido de formalismo usado nas várias visões e níveis da arquitetura pode ser alterado. Um ponto importante a ser ressaltado é o fato de a arquitetura ARIS ser suportada por uma ferramenta chamada ARIS Toolset.

\subsubsection{CIMOSA}

A meta do CIMOSA é ajudar as companhia a gerenciar mudanças e integrar seus meios e operações para alcançar a competitividade global, competindo em preço, qualidade e tempo de entrega. A base para alcançar esse ponto é o modelo de integração empresarial (VERNADAT, 1996).

CIMOSA fornece um consistente framework arquitetural, tanto para a modelagem empresarial quanto para integração empresarial, o qual engloba (VERNADAT, 1996):

- uma definição geral do escopo e natureza do CIM;

- guia de implementação;

- descrição dos sistemas e subsistemas constituintes;

- um framework modular que obedece a padrões internacionais.

Segundo Vernadat (1996) apud (KOSANKE, 1992; VERNADAT, 1992) o CIMOSA cunhou o termo "processos de negócios" e introduziu a abordagem baseada nos processos para modelagem integrada de empresas, ignorando barreiras organizacionais, em oposição às abordagens por função: baseadas em atividades.

\subsubsection{PERA}

O Purdue Enterprise Reference Architecture (PERA) e a relacionada metodologia foram desenvolvidos pela Universidade de Purdue desde 1989. PERA é caracterizado pela sua estruturação em camadas, criadas para cobrir o completo ciclo de 
vida da empresa, desde as definições iniciais e missões, descendo a seus níveis operacionais até a obsolescência da planta final. Cada camada define uma fase de tarefa. Cada fase é informalmente descrita por um documento técnico como um conjunto de procedimentos para conduzir o grupo de usuários através de todas as fases do programa de integração empresarial. (VERNADAT, 1996)

Primeiramente, o PERA se apresenta como uma metodologia completa. É suportado por um simples formalismo gráfico e um manual de fácil compreensão, por ter sido desenhado para a educação dos usuários sem necessária utilização computacional. De fato, os usuários devem poder aplicar a metodologia eles mesmos em suas empresas (na parte ou sistema a ser analisado). (VERNADAT, 1996)

\subsubsection{EKD}

A metodologia EKD foi aplicada inicialmente no contexto do projeto ESPRIT ELEKTRA, em virtude dos conhecimentos obtidos a partir do projeto ESPRIT ELKD.

O EKD é composto de submodelos conceptuais que examinam uma organização e suas exigências a partir de perspectivas inter-relacionadas. Estes sub-modelos são abstrações do mundo físico. Para uma dada empresa, eles constituirão coletivamente o modelo da empresa, cada um representando um aspecto da organização. Os tipos de submodelos são: (1) Modelo de Objetivos; (2) Modelo de Atores e Recursos; (3) Modelo de Regras do Negócio; (4) Modelo de Conceitos; (5) Modelo de Processos de Negócios; e (6) Modelo de Requisitos e Componentes Técnicos. (BUBENKO et al. 2001)

Acoplada a eles pode estar uma informação relevante, direcionando a necessidade para avaliar situações operacionais alternativas. Tal informação inclui critérios para a avaliação, escolhas disponíveis, parâmetros da medida e argumentos. Em todo o estágio de seu desenvolvimento, o modelo da empresa pode servir como os meios da compreensão e da comunicação entre os participantes, ou entre participantes e outras partes interessadas no processo de EKD. Será um ponto de referência comum através de muitas áreas diferentes, de modo que sua posse não seja confinada às aplicações específicas ou aos grupos particulares. Será independente de toda a tecnologia, de forma que o mesmo modelo possa ser executado em diversas plataformas da tecnologia, e remanescerá válido, independente das mudanças tecnológicas. Ele necessitará ser mudado, somente quando a situação e o contexto em que a empresa existe e opera mudarem. Pode ser usado como meio de avaliar opções, de tal maneira 
que os custos de cada opção potencial possam ser tão bem avaliados, que se documentam todos os aspectos intangíveis. (BUBENKO et al., 2001)

O EKD apresenta uma grande facilidade de uso, além de a notação utilizada ter como principal objetivo ser compreendida por todos usuários, sem requerer muito treinamento, poder ser utilizado em situações diferentes e com propósitos diferentes (PÁDUA, 2001).

\subsection{A utilização da metodologia EKD}

Neste contexto, segundo Rolland et al. (2000), o Enterprise Knowledge Development (EKD) se apresenta como uma metodologia que fornece uma forma sistemática e controlada de analisar, entender, desenvolver e documentar uma organização e seus componentes, usando a modelagem organizacional.

O objetivo do uso do EKD é prover uma descrição clara e não-ambígua de (ROLLAND et al. 2000):

- como a organização funciona atualmente;

- quais são os requisitos e as razões para a mudança;

- quais alternativas deveriam ser criadas para encontrar esses requisitos;

- quais são os critérios e argumentos para avaliação dessas alternativas.

De acordo com a concepção de Loucopoulos et al., (1997) e Loucopoulos e Kavakli (1999), o EKD pode ser visualizado segundo três "planos" ou "níveis", aos quais são agregados os seus respectivos modelos ou submodelos (metas, regras do negócio, objetivos, atores, atividades e sistema de informação) (Figura 09).

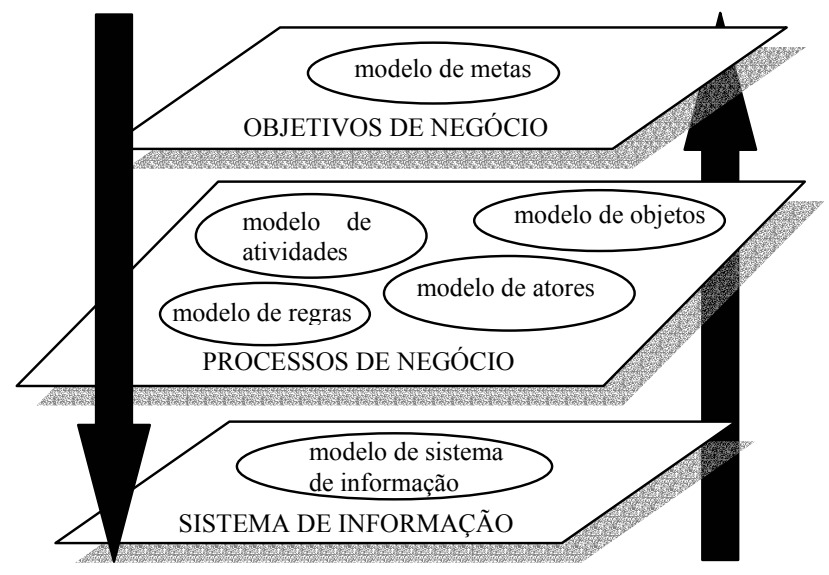

Figura 09: Modelos do EKD. Fonte: ROLLAND, 2000. 
O modelo de metas tem por objetivo representar as metas do empreendimento, e descrever o que ele quer alcançar ou evitar. O modelo de regras do negócio é usado para definir regras empresariais consistentes com o modelo de metas. O modelo de objetos é usado para definir as entidades de empreendimento, atributos e relações. O modelo de atores descreve como eles estão relacionados entre si e as metas. O modelo de atividades é usado para definir processos da empresa e o modo como os recursos são produzidos e utilizados. O modelo de sistema de informação é aplicado para definir as exigências para um sistema de informação. (ROLLAND, 2000)

\subsection{Considerações relevantes sobre a modelagem de obras de construção civil.}

O escopo de atuação do trabalho refere-se a uma rede de cooperação assimétrica (presença de uma hierarquia de poder, com uma empresa ou um grupo de empresas coordenando a rede como um todo) entre empresas autônomas, unidas com o objetivo de agregar competências, de forma a atender uma oportunidade específica (produção do tipo $\mathrm{MTO}^{19}$ ) apresentando uma relação contratual formal.

O processo de negócio de gestão da produção ${ }^{20}$ não ocorre de forma única nas empresas, devendo ser modelado de acordo com as restrições dos diferentes tipos de sistemas produtivos (BREMER e LENZA, 2000). Cabe destacar que, tanto o PCP (De TONI e MENEGHETTI, 2000) quanto a modelagem organizacional (CAMARINHAMATOS e LIMA, 1999) são abordados como promissores mecanismos de coordenação dentro de um ambiente de redes de cooperação. Salienta-se que o tipo de empresa e o tipo de produto dão as restrições necessárias para o desenvolvimento da modelagem (BREMER e LENZA, 2000).

Algumas alianças de empresas são estabelecidas para uma única oportunidade empresarial e são dissolvidas ao término de tal processo. Essa situação corresponde talvez ao caso mais típico de empreendimento virtual para o qual podem ser achados exemplos em sistemas de engenharia de grande escala, como um consórcio de construção envolvido em construir uma única ponte ou uma estrada de ferro (CAMARINHA-MATO e AFSARMANESH, 1999a).

\footnotetext{
${ }^{19}$ Segundo Pires (1995) em uma produção sob encomenda (MTO: make to order), a etapa de produção só inicia após o recebimento do pedido formal; a interação com o cliente costuma ser extensiva, o produto está sujeito a algumas modificações mesmo durante a fase de produção e o projeto básico pode ser desenvolvido a partir dos contatos iniciais com o cliente.

${ }^{20} \mathrm{Na}$ língua portuguesa é freqüente utilizar vários termos para tratar o mesmo assunto, tais como: gestão da produção, gerenciamento da produção, administração da produção e planejamento e controle da produção (PIRES, 1995).
} 
Segundo Tsakopoulos e Bokma (2000), o setor da construção por um longo tempo tem trabalhado na forma de empresa virtual, porém com relativa obsolescência do uso da tecnologia de informação, a qual aparenta ser o ponto-chave para a operacionalização da empresa virtual.

Bett (1992) apud Tsakopoulos e Bokma (2000) argumenta que o menor progresso da tecnologia de informação no setor da construção civil em comparação com outros setores ocorre em função da sua comparativa complexidade. Uma vez que o setor da construção, fazendo parte da indústria de engenharia e produção sob encomenda (MTO), apresenta algumas características de operação que condicionam um planejamento e controle da produção mais complexo, essa complexidade tem como resultado a ausência de um adequado e explícito sistema de informação (CHAMBERS et al., 2000).

Nesse sentido, Tsakopoulos e Bokma (2000) propõem um método ante os conceitos de empresa virtual, que torna o planejamento e controle no setor da construção civil mais eficientes. Existem duas fases principais neste método: a primeira designa os processos, e a segunda traduz os processos designados em uma forma que possa ser executada pelo workflow ${ }^{21}$ (fluxo de trabalho). Referentes à primeira fase, são propostos três ciclos para poder produzir uma especificação sistemática para um sistema de workflow (TSAKOPOULOS e BOKMA, 2000):

- Ciclo 1 - Papéis e responsabilidades: Em primeiro lugar, os participantes do projeto $^{22}$ são identificados e os relacionamentos e as respectivas responsabilidades são estabelecidas para que os participantes sejam alocados na estrutura da organização. O ciclo 1 termina assim que eles tenham sido especificados e que aceitem as responsabilidades e os papéis a eles nomeados (fazendo uma analogia com Britto (2002), pode-se aqui identificar os nós como participantes e as posições são determinadas quando estabelecidos os relacionamentos e responsabilidades dos participantes). Wiendahl e Harms (2000), utilizando um conceito de agentes de produção, levantam a viabilidade da utilização do relacionamento preço versus data de

\footnotetext{
${ }^{21}$ Por tecnologia de workflow entende-se um conjunto de ferramentas que possibilita a automação dos processos da organização. Workflow apresenta-se como um instrumento tecnológico para a transformação do conhecimento organizacional. (THIVES Jr., 2002)

${ }^{22}$ A palavra projeto tem o significado de obra referindo-se ao setor de construção.
} 
entrega (critérios competitivos $^{23}$ ) como mecanismos de negociação e determinação dos participantes em um planejamento e controle da produção descentralizada, no qual cada agente só representa um passo do processo. Os resultados de cada passo do processo são os produtos que seu agente pode produzir, portanto, os agentes de produção devem atuar conjuntamente para fabricar os produtos finais (WIENDAHL e HARMS, 2000)

- Ciclo 2 - Especificação de tarefa: Seguindo a aprovação unilateral do ciclo 1 , cada participante terá que definir as suas respectivas subtarefas, para que não só se especifique o objetivo do participante, mas também os recursos necessários, incluindo-se os esforços e materiais para todo o período de duração do projeto.

- Ciclo 3 - Especificação de dependência de tarefa: Uma vez que as tarefas foram identificadas e foram aprovadas, elas precisam ser interconectadas mostrando-se suas interdependências, e cada uma só começa a ser realizada após a notificação a seu responsável de que a atividade anterior foi concluída. O objetivo é especificar uma sucessão realística de eventos que assegurem a execução do projeto inteiro. Isso é realizado através da notificação da conclusão de uma tarefa comunicada ao indivíduo, responsável pela próxima tarefa, que pode começar suas atividades neste momento.

A segunda fase deste método utilizará as especificações estabelecidas na fase $1 \mathrm{e}$ produzirá uma plataforma de workflow, baseada nas tarefas e nas interdependências delas.

Em uma organização "isolada" MTO, usualmente o programa mestre de produção é previamente estabelecido com base no pedido do cliente e previamente estabelecido o lote econômico. Então, sua viabilidade é checada pelo MRP (planejamento das necessidades de materiais) e CRP (planejamento das capacidades requeridas), e finalmente no SFC (controle do chão de fabrica) as tarefas são designadas aos existentes centros de trabalho e seqüenciadas (De TONI e MENEGHETTI, 2000). Em uma rede de diferentes empresas, em vez disso, o tradicional conceito de tamanho do lote é substituído por um mais relacionado a um período de tempo, antes do qual uma certa quantidade de peças ou uma certa atividade deve estar processada (De TONI

${ }^{23}$ Slack (1993) delineou cinco prioridades competitivas principais: custo, qualidade, velocidade de entrega, confiabilidade de entrega e flexibilidade. 
e MENEGHETTI, 2000), o que demonstra a importância desempenhada pelo critério competitivo relacionado a tempo de execução e capacidade produtiva em sistemas de produção do tipo MTO.

Portanto, considerando-se as companhias de engenharia e produção sob encomenda (E\&MTO) envolvidas em um cenário baseado no paradigma da Empresa Virtual, atualmente caracterizada por um baixo nível de automatização em controle, planejamento e programação da produção, duas são as propostas relativas à sua automatização (CHAMBERS et al. 2000):

- Primeiramente, a automatização deveria examinar todo o fluxo de informação, quando considerasse o processo de PCP e os atores internos e externos. Essa automatização tem que acontecer dentro de um sistema de informação aberto e distribuído.

- Secundariamente, o sistema de informação deveria ser flexível o bastante para permitir sua integração com vários sistemas de informação externos.

Uma vez que o processo de negócio global foi definido e programado, as responsabilidades são individualmente endereçadas aos parceiros, de forma que alcançar o objetivo em comum irá depender da apropriada operação de cada membro da Empresa Virtual (CAMARINHA-MATOS e LIMA, 1999). Mezgár et al., (2000) vinculados ao projeto PLENT (Planning Small-Medium Enterprise Network: ESPRIT Project n.20723), propõem um modelo de rede com o planejamento da produção cooperativa, no qual a coordenação da rede é fundamentada na sua base de informações que contém os seguintes elementos: a descrição das entidades do sistema (unidade de coordenação, nós, clientes) e o modelo dos processos básicos. E o ponto mais importante é a descrição da distribuição dos processos ao longo da rede em termos das fases realizadas por diferentes nós para alcançar o objetivo em comum.

Para adquirir a requerida rede com neutralidade de coordenação, três módulos de softwares são requeridos (MEZGÁR et al., 2000):

1. Módulo de coordenação: Realiza a política de planejamento da rede e é responsável por controlar a conexão com o exterior da rede, manter contato com os clientes, selecionar apropriados nós (unidades produtoras) e distribuir as obrigações da produção ao longo desses nós.

2. Módulo de planejamento local: Suporta as atividades relacionadas à rede que estão a cargo de cada nó. Ele realiza o controle de tarefas de cada nó da rede, 
de forma a satisfazer as metas do gerenciamento e da comunicação, entregando as informações do status de cada nó para os outros nós.

3. Módulo de avaliação da performance: Dá suporte ao trabalho da unidade de coordenação durante a seleção do melhor para desempenhar as tarefas, e gera diferentes avaliações, estatísticas e estimativas baseadas em comportamento anteriores dos nós.

\subsection{Considerações finais}

Nessa conjuntura, apresenta-se um modelo inicial de referência, segundo a metodologia do EKD (Figura 10), no qual se aborda o Ciclo de Vida da rede, agregando a ele os quatro elementos morfológicos propostos por Britto (2002) (nós, posições, ligações e fluxos), balizado pelo processo de negócios Produzir, responsável por planejar e adquirir os recursos necessários a fim de converter entradas em produtos, englobando atividades do PCP que possuem a finalidade de aumentar a eficiência e eficácia do processo produtivo das empresas e da rede.

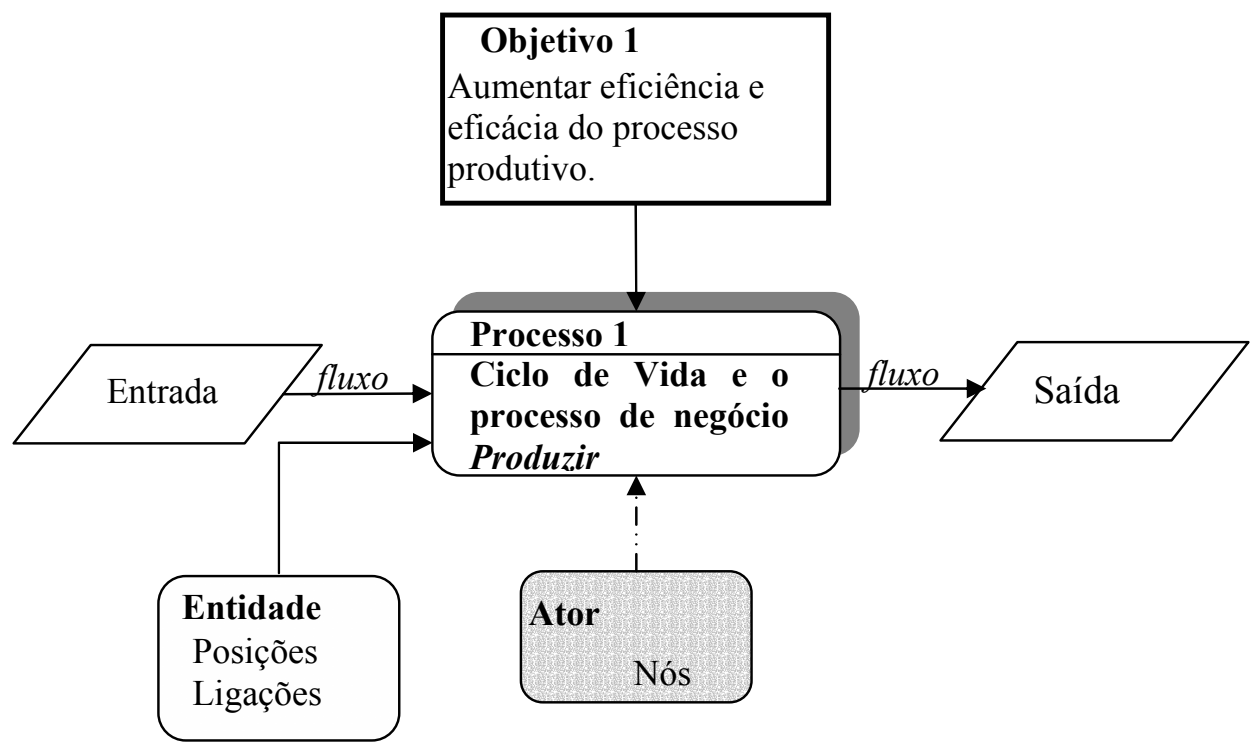

Figura 10: Modelo inicial, proposto segundo o EKD.

Estabelecida a base teórica para compreensão dos temas abordados, a seguir. será apresentada a coleta de dados do estudo de caso em uma obra de construção civil de grande porte. 
ESTUDO DE CASO 


\section{COLETA DE DADOS}

\subsection{Introdução}

Este capítulo tem o objetivo levantar dados por meio de um estudo de caso de caráter exploratório em uma obra de construção civil de grande porte.

O Estudo de caso é um dos vários modos de realizar uma pesquisa sólida. A necessidade de se utilizar a estratégia do "estudo de caso" deve nascer do desejo de entender um fenômeno social complexo (YIN, 2001).

O estudo de caso é utilizado quando os pesquisadores têm por intenção suportar seus argumentos por uma profunda análise da pessoa, grupo de pessoas, de uma organização ou um projeto particular, ou seja, o estudo de caso foca em um aspecto do problema, chegando a conclusões relacionadas a um evento em particular, não vindo a ser generalizadas e proporciona uma análise profunda de um problema específico (NAOUM, 2000).

Existem três tipos de estudo de caso:

- Estudo de caso descritivo: estabelece uma relação entre objetos e atributos (conta, recenseamento), exceto a ser aplicado em casos detalhados.

- Estudo de caso analítico: estabelece uma relação entre objetos e atributos (conta, recenseamento, associação e relacionamento), exceto a ser aplicado em casos detalhados.

- Estudo de caso exploratório: é uma abordagem teórica para o problema, explicando a causalidade e apresentando as ligações entre os objetos de estudo.

O estudo de caso abordado é de caráter exploratório, pois há a necessidade de coletarem-se dados para a compreensão da viabilidade do PCP no ambiente de redes de empresas. 
A Figura 11 detalha a metodologia que será utilizada no estudo de caso.

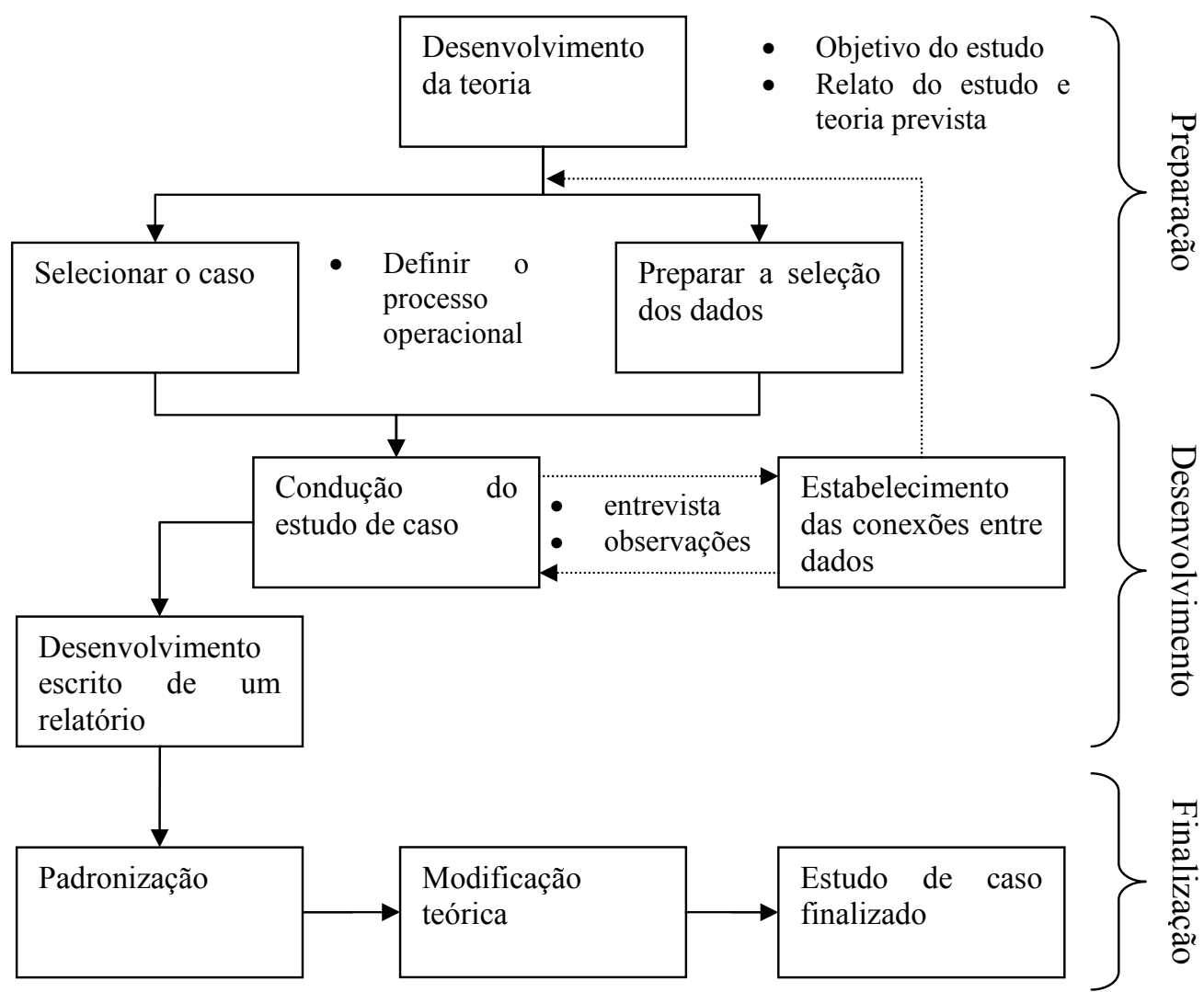

Figura 11: Etapas relevantes para elaboração de um Estudo de Caso. Fonte: YIN, 2001.

A pesquisa foi realizada em uma obra de construção civil de grande porte (por deter características de interesse para o desenvolvimento do trabalho: grupo de empresas autônomas, unidas com o objetivo de agregar competência de forma a atender uma oportunidade específica, apresentando uma relação contratual formal, com a presença marcante de uma hierarquia de poder), mais especificamente no arranjo do Planejamento e Controle da Produção em um ambiente de produção distribuída.

Como instrumentos, para realizar a pesquisa foram propostas entrevistas, visitas e observações na obra e nas empresas, visando identificar o modus operandi, determinando o perfil e as características do Planejamento e Controle da Produção, para comparações com a teoria e com o modelo proposto, a fim de cumprir a proposta deste trabalho.

O objeto de análise será a obra de implementação da Linha 4 do metrô de São Paulo. Contudo os alvos são as inter-relações existentes entre as empresas que compõem o consórcio para a realização de uma obra/empreendimento civil, 
posicionadas no topo da hierarquia de comando e gestão do consórcio da obra em questão.

O trabalho foi realizado mediante dois tipos de levantamentos de dados: os dados primários que são aqueles coletados pela primeira vez através do pesquisador e os dados secundários que já analisados e disponíveis na bibliografia, trabalhos e relatórios entre outros. Para a coleta de dados primários pretende-se focar no desenvolvimento de entrevistas, visitações e observações de caráter qualitativo. Não houve a utilização de questionários estruturados, pois os questionamentos surgiram a partir da análise da documentação da obra e das observações feitas durante as visitas na obra.

Com o intuito de direcionar a execução da pesquisa de campo, pretende-se responder às seguintes questões:

1) Uma obra de construção civil, com características de grande porte, executada a partir de um consórcio, possui um sistema de planejamento e controle de produção (PCP) ?

2) Em caso afirmativo, como a hierarquia de decisões do PCP se articula?

3) Como são definidos os agentes da estrutura de governança do consórcio?

4) Em função da resposta da questão 3, como se articulam os nós, posições, ligações e fluxos que caracterizam a morfologia de redes?

5) Como é feito o plano de recursos?

6) De que forma são analisadas as capacidades e competências das empresas que compõem o consórcio?

7) Como são atribuídas as responsabilidades?

\subsection{Diretrizes para a criação do consórcio}

O nome oficial do Projeto é "Implementação da Linha 4 do Sistema de Metrô de São Paulo".

A Implementação da Linha 4 do Sistema de Metrô de São Paulo tem uma função estratégica na integração e operação do transporte público metropolitano, pois o projeto de sua rota tem como diretriz a busca pela melhor integração possível com o metrô, com as redes de estrada de ferro existentes e com os sistemas de ônibus municipal e intermunicipal. A linha, unindo a região sudoeste ao centro metropolitano da cidade é considerada como essencial para a articulação de tal sistema, uma vez que, proporcionará conexões com as Linhas: 1 - Azul, 2 - Verde, 3 - Vermelho, 6 - Laranja e 7 - Azul Céu. 
A Companhia do Metropolitano de São Paulo - METRÔ, companhia estatal reportada à Secretaria de Transporte Metropolitano do Governo do Estado de São Paulo, pediu ofertas para a construção da Linha 4 do Sistema de Metrô de São Paulo, através de uma oferta competitiva internacional. A oferta é administrada conforme as regras e procedimentos estabelecidos nas Diretrizes: Obtenção de Empréstimos IBRD e Créditos do IDA $^{24}$, como autorizado pelo parágrafo 5 do artigo 42 da Lei Federal $n^{\circ}$ 8666/93, e da Lei Estadual n ${ }^{\circ}$ 6.544/89 nos aspectos não conflitantes com as Diretrizes do IBRD.

As informações contidas nesse item fazem parte do contrato da obra. Elas foram devidamente checadas por meio de verificação in loco e entrevistas.

Condizendo com Conte (1997), que argumenta, mediante um apropriado conjunto de documentos antecipa-se os resultados esperados dos trabalhos a serem realizados, o Programa de Execução (Anexo A) descreve uma documentação técnica a ser elaborada e utilizada ao longo de cada etapa auxiliando na antecipação de eventos e na programação de atividades, documentação esta composta por: ID (Índice de Documentos), Plano geral de trabalho, cronograma de barras tipo Gantt e rede CPM, entrega da tabela CPM e Gantt específicas de trabalho civil, projeto executivo (remanejamento de interferências, desvio de tráfego, contenção e fundações, obra bruta, acabamento, paisagismo e urbanização, e procedimentos executivos).

O Projeto é desenvolvido em duas fases, contendo a elaboração dos projetos executivos civis e de sistemas, construção e execução das obras civis, vias, fornecimento e implantação de equipamentos e sistemas necessários. A primeira, representando o objeto de análise desta pesquisa, consiste em 12,8 Km de extensão entre Morumbi e Estação da Luz, incluindo o Pátio de Manutenção da Vila Sônia (infraestrutura, vias, edificações e parte dos sistemas), construção completa de 5 estações (Luz, República, Paulista, Pinheiros e Butantã), 5 estações de ventilação e 11,5 km de túneis, construção parcial de 4 estações, provisão e montagem dos sistemas necessário à operação parcial da Linha. Os Sistemas a serem providos incluem telecomunicações, fornecimento de energia (primário, auxiliar e subestações retificadoras) e todo o equipamento auxiliar. A segunda fase consiste na conclusão das 4 estações da primeira fase e construção de duas estações novas, provisão dos sistemas e todo o material rolante para permitir a operação da Linha 4 - Amarela. Esta segunda fase será objeto de outra licitação.

\footnotetext{
${ }^{24}$ Montante do Empréstimo: US \$209,000,000 equivalente
} 
Os agentes que compõem a estrutura de governança da obra são:

- Empregador: Companhia do Metropolitano de São Paulo - Metrô, em nome do Governo do Estado de São Paulo.

- Gerente de Projeto: O Gerente de Projeto representa e age para o Empregador durante todo o período de duração do Contrato. Todas as observações, instruções, ordens, certificados, aprovações e todas as demais comunicações acerca do Contrato são dadas pelo Gerente de Projeto, exceto quando indicado a ser realizado de outro modo. Todas as instruções, informações e outras comunicações dadas pelo Contratante ao Empregador acerca do Contrato, são dadas ao Gerente de Projeto, exceto quando indicado a ser realizado de outro modo.

- Contratante: Empresa(s) cuja oferta foi aceita pelo Empregador e nomeado como tal no Acordo de Contrato. Neste escopo, o Joint Venture/Consórcio limita-se a 4 (quatro) membros.

- Concessionária: Empresa(s) contratada pelo Empregador para a operação das Instalações sob um contrato de concessão de 30 anos, que inclui o fornecimento e a instalação de outros equipamentos complementares necessários.

- Representante da Concessionária: Representa a Concessionária e atua como conselheiro ao Gerente de Projeto durante todo o período de duração do Contrato, facilitando a coordenação entre os trabalhos sob a responsabilidade da Concessionária e aqueles do Contratante.

- Representante do Contratante: Representa e age para o Contratante durante todo o período de duração do Contrato e dá ao Gerente de Projeto todas as observações, instruções, informações e demais comunicações acerca do Contrato, referentes ao Contratante. Todas as instruções, informações e outras comunicações, dadas pelo Empregador ao Contratante acerca do Contrato, são dadas ao Gerente de Projeto, exceto quando indicado a ser realizado de outro modo. Do começo da implantação das Instalações no local da Obra até a conclusão, o Representante do Contratante supervisionará todo o trabalho feito no local da Obra pelo Contratante e deve estar presente no local durante as horas normais de funcionamento, exceto quando de licença, doente ou ausente por razões conectadas com o apropriado desempenho do 
Contrato. Sempre que o Representante do Contratante se ausentar do local da Obra, uma pessoa apropriada é apontada para o ato como seu agente.

- Subcontratante: Pessoa para a qual a execução de qualquer parte das Instalações (incluindo a preparação de qualquer projeto ou fornecimento de quaisquer equipamento e sistemas) é subcontratada diretamente ou indiretamente pelo Contratante, incluindo vendedores.

- Banco Mundial (The World Bank): É o mesmo que Banco Internacional para Reconstrução e Desenvolvimento (IBRD) ou Associação Internacional de Desenvolvimento (IDA).

\subsubsection{Configuração da obra}

O Contrato é do tipo Turn-Key (entrega pronta para operação) constituído de projetos, construção, provisão e instalação para $12,8 \mathrm{~km}$ de linhas de metrô. O Valor do Contrato é uma soma global firmada, e nenhum pagamento feito pelo Empregador são julgados a constituir a aceitação, pelo Empregador, das Instalações ou qualquer parte(s) dela. O Contrato é o instrumento a partir do qual são estabelecidas todas as posições e ligações entre as empresas que fazem parte da obra, definindo responsabilidades em cada etapa da obra e a respectiva organização do planejamento e controle de execução da obra. O total dos trabalhos a serem realizados foram divididos em três lotes (Lote 1 Paulista, Lote 2 - Pinheiros e Lote 3 - Pátio Vila Sônia) aos quais foram submetidas ofertas concorrentes.

\section{Está previsto no Contrato:}

a) Trabalhos Civis: demolição de edificações, remoção de interferências, túneis, estruturas, estações, rotas permanentes (Vias), serviços de finalização, paisagismo, urbanização e serviços complementares.

b) Sistemas: provisão de energia, sistemas de energia de alta e média voltagem $\mathrm{AC}$, sistema de energia de tração DC (subestação de retificação e linha de contato), sistema de energia de baixa voltagem (não incluindo nenhuma bateria), sistemas auxiliares (bombas e controles de nível, detectores de fogo, salas técnicas de ventilação), sistemas de telecomunicação, sistema de controle local, iluminação, escadas rolantes e elevadores.

Os detalhamentos do Contrato específico a cada um dos lotes estão descritos nas Tabelas (04, 05 e 06) a seguir: 
Tabela 04 - Descrição do Lote 1 - Paulista

\begin{tabular}{|c|c|}
\hline ISTA & \\
\hline $\begin{array}{c}\text { TRABALHOS CIVIS } \\
\text { Trabalhos civis da seção entre João Teodoro e a } \\
\text { estação Fradique Coutinho (não incluída). Os } \\
\text { trabalhos civis incluem: }\end{array}$ & $\begin{array}{c}\text { SISTEMAS } \\
\text { Os sistemas incluem: }\end{array}$ \\
\hline 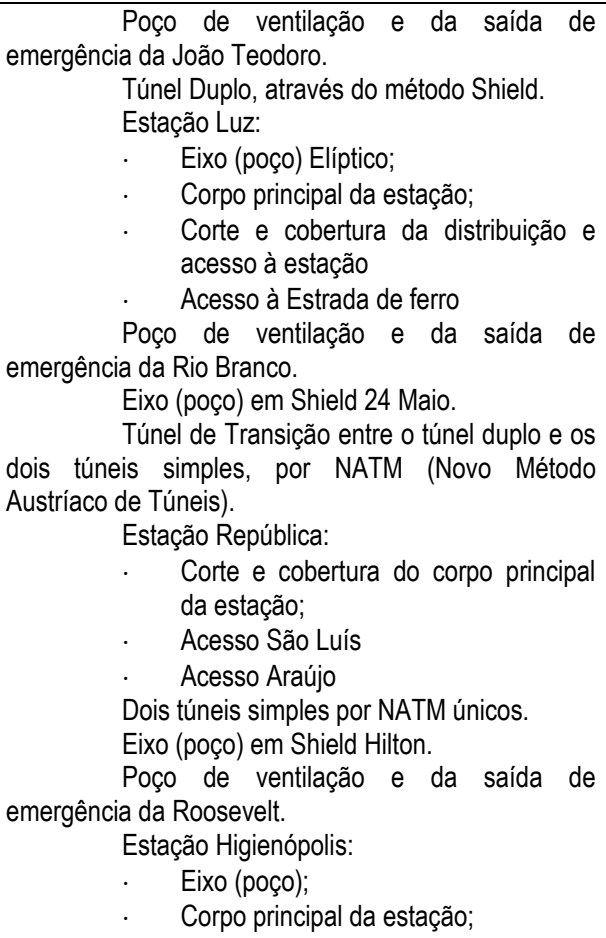 & 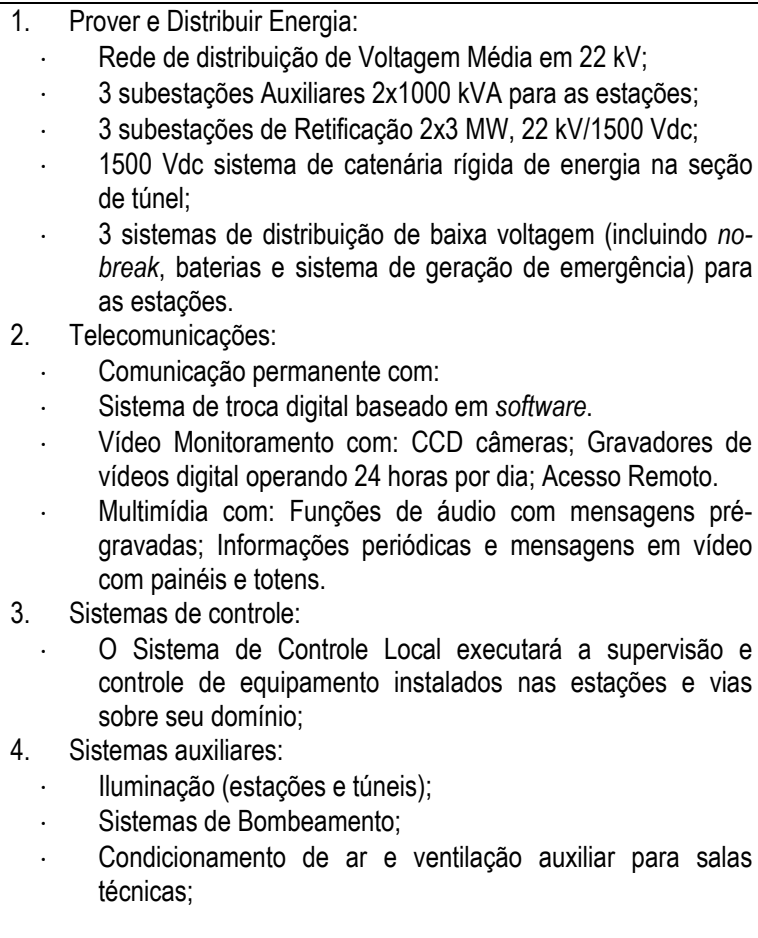 \\
\hline $\begin{array}{l}\text { Acesso Mackenzie (parcial); } \\
\text { Poço de ventilação e da saída de } \\
\text { emergência da José Eusébio. } \\
\text { Área de armazenamento dos trens em } \\
\text { Túneis NATM. } \\
\text { Estação Paulista: } \\
\quad \text { 2 Eixos (poços); } \\
\text {. Acesso Belas Artes; } \\
\text {. Corpo principal da estação; } \\
\text {. Salas operacionais e Técnicas; } \\
\text {. Túnel de Conexão; } \\
\text {. Acesso Angélica; } \\
\text {. Linha de Ligação dos dois Acessos; } \\
\text {. Túnel do Acesso Angélica. } \\
\text { Poço de ventilação e da saída de } \\
\text { emergência da Incor. } \\
\text { Estação Oscar Freire: } \\
\text {. Eixo (poço); } \\
\text {. Acesso Jardins (parcial); } \\
\text {. Corpo principal da estação; } \\
\text {. Túnel de conexão. } \\
\text { Poço de ventilação e da saída de } \\
\text { emergência da Brasil. } \\
\text { Os trabalhos finais das Estações Luz, } \\
\text { República e Paulista, poço de ventilação e da saída de } \\
\text { emergência. } \\
\text { Nos serviços estarão incluídos: serviços } \\
\text { das vias permanentes, incluindo sistemas de } \\
\text { abafamento de vibração e barulho. }\end{array}$ & 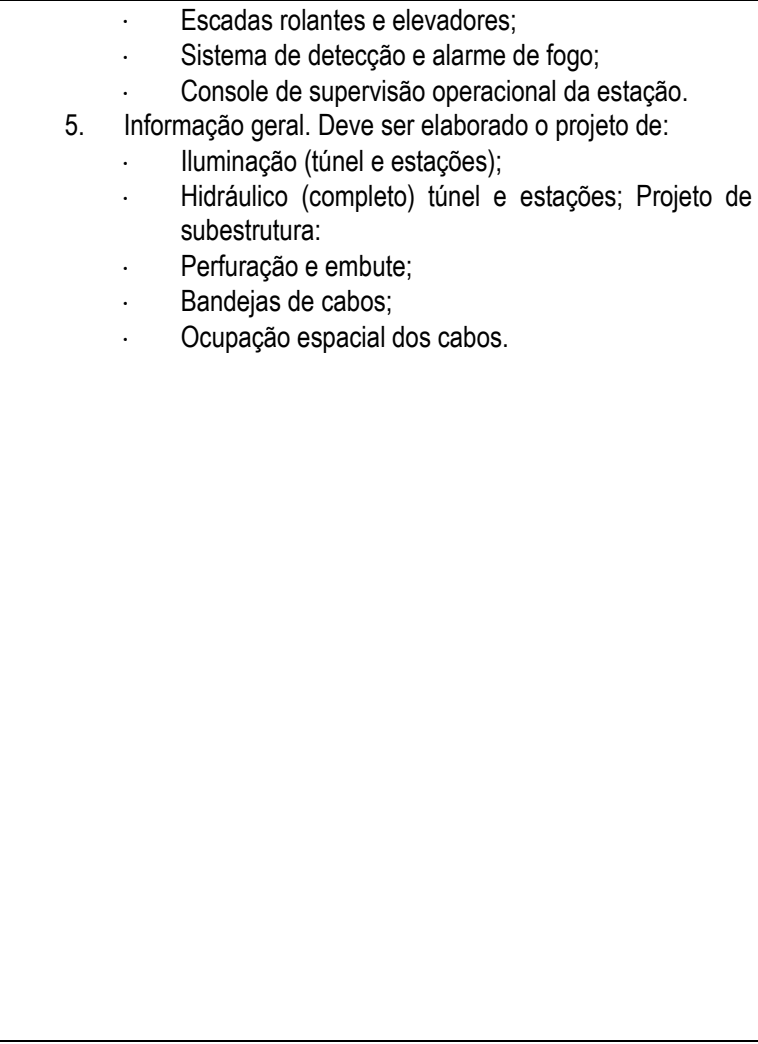 \\
\hline
\end{tabular}


Tabela 05 - Descrição do Lote 2 - Pinheiros.

\begin{tabular}{|c|c|}
\hline I & \\
\hline $\begin{array}{c}\text { TRABALHOS CIVIS } \\
\text { Trabalhos civis da seção entre Estação } \\
\text { Fradique Coutinho (incluída) e o corte e } \\
\text { cobertura do acesso ao Pátio Vila Sônia. } \\
\text { Os trabalhos civis incluem: }\end{array}$ & $\begin{array}{c}\text { SISTEMAS } \\
\text { Os sistemas incluem: }\end{array}$ \\
\hline 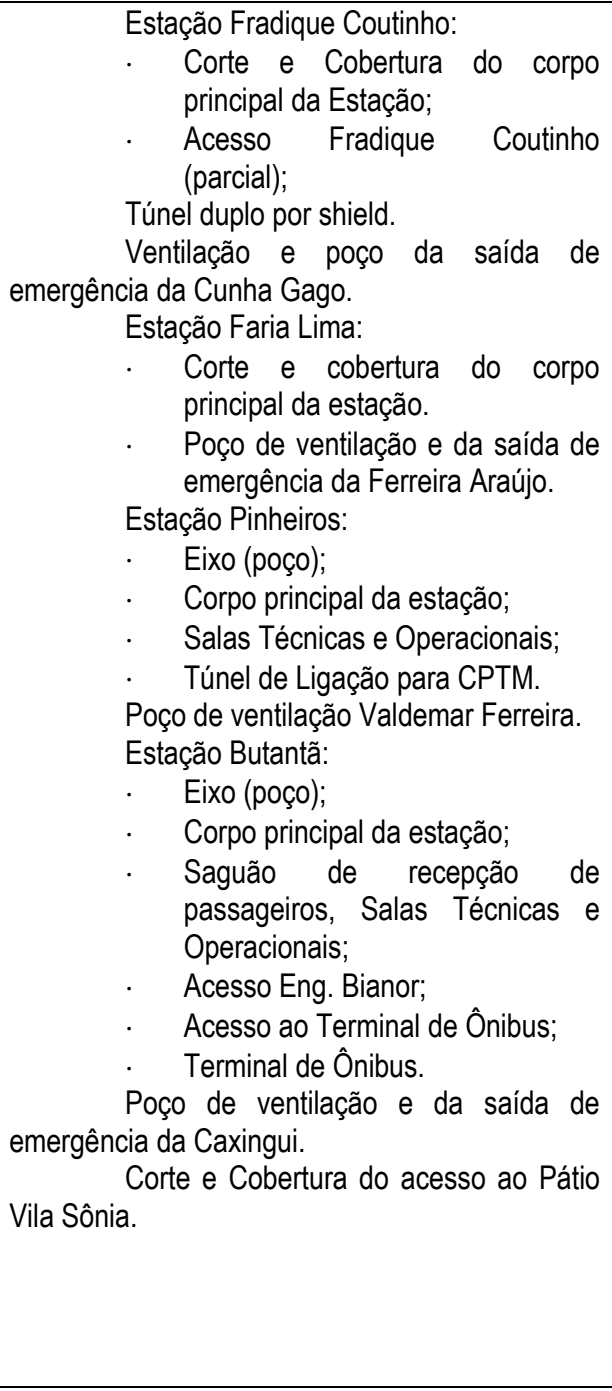 & 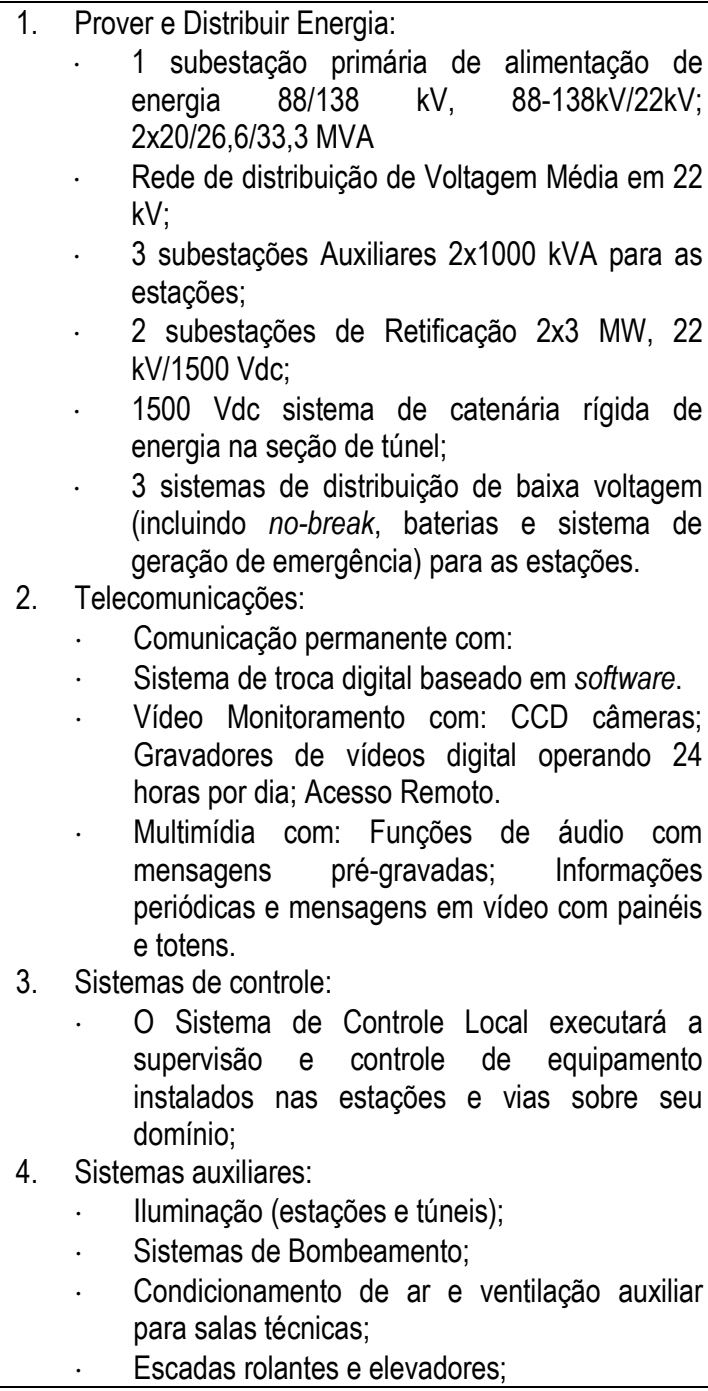 \\
\hline $\begin{array}{l}\text { Corte e Cobertura do acesso ao Pátio } \\
\text { Vila Sônia. } \\
\text { Os trabalhos finais das Estações } \\
\text { Pinheiros e Butantã, poço de ventilação e da } \\
\text { saída de emergência. } \\
\text { Nos serviços estarão incluídos: } \\
\text { serviços das vias permanentes, incluindo } \\
\text { sistemas de abafamento de vibração e barulho. }\end{array}$ & $\begin{array}{l}\text {. } \quad \text { Sistema de detecção e alarme de fogo; } \\
\text {. } \quad \text { Console de supervisão operacional da estação. } \\
\text { Informação geral. Deve ser elaborada o projeto de: } \\
\text {. } \quad \text { lluminação (túnel e estações); } \\
\text {. } \quad \text { Hidráulico (completo) túnel e estações; } \\
\text {. } \quad \text { Projeto de subestrutura: } \\
\text {. } \quad \text { Perfuração e embute; } \\
\text {. } \quad \text { Bandejas de cabos; } \\
\text {. } \quad \text { Ocupação espacial dos cabos. }\end{array}$ \\
\hline
\end{tabular}


Tabela 06 - Descrição do Lote 6 - Pátio Vila Sônia.

LOTE 3 - PÁTIO VILA SÔNIA

\begin{tabular}{|c|c|}
\hline $\begin{array}{c}\text { TRABALHOS CIVIS } \\
\text { Os trabalhos civis incluem: }\end{array}$ & $\begin{array}{c}\text { SISTEMAS } \\
\text { Os sistemas incluem: }\end{array}$ \\
\hline $\begin{array}{l}\text { Trabalhos civis do Pátio } \\
\text { Vila Sônia, inclui movimentação } \\
\text { de terra, sistema de drenagem, } \\
\text { edifícios e outras estruturas } \\
\text { componentes do Pátio e os } \\
\text { trabalhos de finalização. } \\
\text { Nos serviços estarão } \\
\text { incluídos: serviços das vias } \\
\text { permanentes, incluindo sistemas } \\
\text { de abafamento de vibração e } \\
\text { barulho. }\end{array}$ & 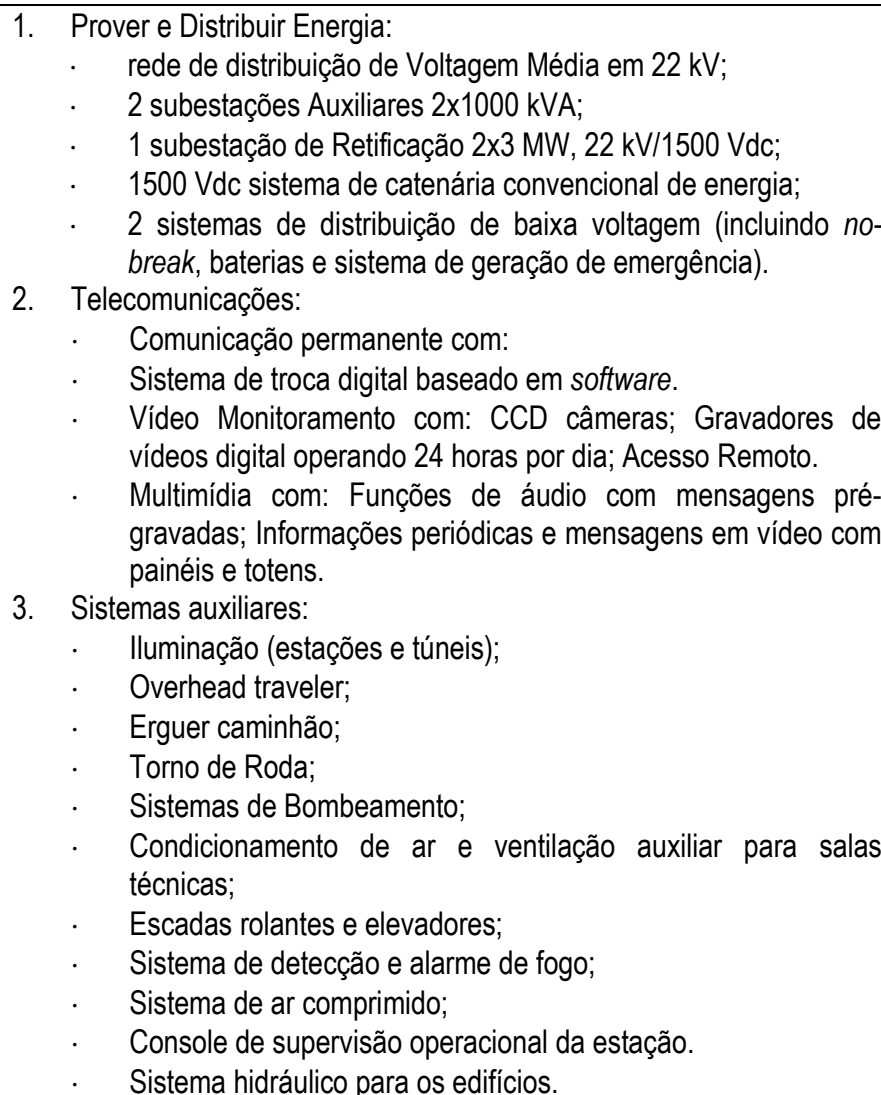 \\
\hline & $\begin{array}{l}\text { 4. Veículos auxiliares para a Linha 4: } \\
\text {. } 3 \text { carros locomotivos movimentadores com sistema bimodal de } \\
\text { roda; } \\
\text {. } \quad \text { Veículo para instalação e manutenção do sistema de tração } \\
\text { overhead; } \\
\text {. } 1 \text { carro plataforma reboque de carga; } \\
\text {. } 1 \text { vagão de limpeza de alta pressão para trilhos e vias; } \\
\text {. } \quad 20 \text { trolley de transporte para trilhos; } \\
\text {. } 1 \text { veiculo de esmerilhar trilhos; } \\
\text {. } 1 \text { caminhão de manutenção com sistema de rodas bi-modal; } \\
\text {. } 1 \text { pick-up cabine dupla com sistema de rodas bi-modal; } \\
\text {. } \quad 1 \text { caminhão com braço móvel com sistema de rodas bi-modal; } \\
\text {. } \quad 2 \text { caminhões padrão com sistema de rodas bi-modal. } \\
\text { Informação geral. Deve ser elaborado o projeto de: } \\
\text {. } \quad \text { Iluminação (túnel e estações); } \\
\text {. Hidráulico (completo) túnel e estações; } \\
\text {. } \quad \text { Projeto de subestrutura: } \\
\text {. } \quad \text { Perfuração e embute; } \\
\text {. Bandejas de cabos; } \\
\text {. Ocupação espacial dos cabos. } \\
\text {. } \quad \text { Principais tubos subterrâneos para os cabos. }\end{array}$ \\
\hline
\end{tabular}




\subsubsection{Elegibilidade de Países e Licitantes}

A licitação foi aberta a todas as empresas elegíveis de países de fonte elegíveis. O Banco mantém uma lista de países dos quais licitantes de bens e serviços não são elegíveis para participar de contratação financiada por ele. A lista é atualizada regularmente e pode ser obtida do InfoShop do Banco em Washington D.C., e nos Centros de Informação Públicos do Banco em Paris e Tóquio. Joint Ventures/Consórcios que inclua sócios de países de fonte inelegíveis, ou empresas inelegíveis, não poderão participar da licitação.

Uma empresa que foi engajada pelo Prestatário para prover serviços de consultoria para a preparação ou implementação de um projeto e quaisquer de seus afiliados seria desqualificada de prover bens ou trabalhos subseqüentemente (outro que não a continuação dos iniciais serviços de consultorias) para o mesmo projeto.

Empresas com participação estatal, no país do Prestatário, só poderiam participar se elas pudessem estabelecer que (i) são legalmente e financeiramente autônomas, e (ii) opere segundo as leis comerciais. Nenhuma agência dependente do Prestatário ou Subprestatário diante de um projeto Banco-financiado seria permitida licitar ou submeter uma proposta para a obtenção de bens ou trabalhos segundo o projeto.

Uma empresa declarada inelegível pelo Banco, conforme padrões de ética ${ }^{25}$, seria inelegível a oferta para um contrato banco-financiado durante o período de tempo determinado pelo Banco.

\subsubsection{Critérios de qualificação baseados na capacidade e recursos}

A pré-qualificação foi baseada nos Candidatos atenderem a todos os critérios mínimos que consideram a experiência geral e particular, experiências em construção civil, experiências em provisão e instalação de energia, fornecimento de sistemas para metrô, situação financeira, capacidades de pessoal e de equipamento, e outra informação pertinente requerida. A qualificação, capacidade e recursos de subcontratantes propostos não foram levadas em conta na avaliação de Candidatos individuais ou de Joint Venture/Consórcios, a menos que eles fossem nomeados Subcontratantes Especialista.

\footnotetext{
${ }^{25}$ É a política de Banco requerer que os Prestatários (inclusive beneficiários de empréstimos bancários), como também licitantes de bens e serviços, diante de contratos banco-financiados, observem o mais alto padrão de ética durante a obtenção e execução do Contrato em contraposição a "prática de corrupção" e "práticas fraudulentas".
} 
Se um Candidato pretender subcontratar quaisquer elementos altamente especializados dos trabalhos para Subcontratantes Especialistas, o Candidato deve identificar tais elementos e os Subcontratantes propostos claramente, e descrever a experiência e capacidade pertinentes dos Subcontratantes.

Os Subcontratantes Especialistas não precisam ser exclusivos e podem participar como Subcontratantes em outras ofertas, mas eles não podem ser um sócio de qualquer dos Candidatos. A empresa de consultoria que foi contratada pela Companhia do Metrô para o projeto de qualquer lote será desqualificada por prover serviços de consultoria para o mesmo lote como sócio ou como Subcontratante de qualquer Candidato.

O Candidato pode subcontratar até $20 \%$ dos trabalhos civis e de todo o equipamento a ser provido. Além disso, se o Candidato pretende subcontratar mais que $10 \%$ do Valor do Contrato, esta intenção é declarada junto com uma lista-tentativa dos elementos do Contrato a ser subcontratado. Os fabricantes dos equipamentos a serem providos não necessitam ser pré-qualificados e não precisam ser listados na fase de préqualificação, porém, licitantes têm que indicar nas suas ofertas todo o equipamento que proverão, com as especificações técnicas completas e a autorização dos fabricantes para provisão de equipamentos maiores, identificados nos documentos de licitação. Neste sentido, o correspondente apêndice, Lista de Subcontratantes Aprovados, do Acordo de Contrato, especifica os principais itens de fornecimento ou serviços e uma lista de Subcontratantes aprovados em relação a cada item, incluindo os vendedores e a indicação dos Subcontratantes Especialistas inclusos na proposta do Contratante. O Contratante pode propor qualquer alteração da lista, porém, ele deve submeter todas as listas ou todas as modificações nestas ao Empregador, para sua aprovação, em tempo suficiente, de modo a não impedir o progresso de trabalhos nas instalações. Tal aprovação, para quaisquer dos Subcontratantes, não aliviará o Contratante de quaisquer de suas obrigações, deveres ou responsabilidades sob o Contrato.

O Empregador pode exigir que os Candidatos forneçam mais informações sobre suas propostas. Se qualquer Subcontratante proposto for considerado inelegível ou inadequado para realizar uma tarefa indicada, o Empregador pode pedir para que o Candidato proponha um substituto aceitável.

Em relação à experiência geral, o Candidato deve comprovar que:

a) esteja ativamente comprometido no negócio de construção civil por pelo menos o período declarado (Tabela 7), antes da data de submissão das 
propostas, no papel de contratante principal, contratante de administração, sócio em um Joint Venture/Consórcio, ou subcontratante.

Tabela 07 - Experiência geral, período de tempo no negócio de construção.

\begin{tabular}{lc}
\hline (a) Período de Tempo no Negócio de Construção: \\
\hline Lote & Período de Tempo no Negócio de Construção \\
1 Paulista & cinco (5) anos ou mais \\
2 Pinheiros & cinco (5) anos ou mais \\
3 Pátio Vila Sônia & cinco (5) anos ou mais \\
\hline
\end{tabular}

b) ou foi ativamente comprometido na administração de provisão e instalação de equipamento para Sistemas de Provisão de Energia, pelo menos para o período declarado (Tabela 8), antes da data de submissão das propostas, no papel de contratante principal, contratante de administração, sócio em uma Joint Venture/Consórcio, ou subcontratante.

Tabela 08 - Experiência geral, período de tempo no negócio de instalação de equipamento e sistemas.

\begin{tabular}{ll}
\hline (b) Período de Tempo no Negócio de Instalação de Equipamento e Sistemas: & \\
\hline Lote & Período de Tempo no Negócio de Instalação de \\
& Equipamento e Sistemas \\
1 Paulista & três (3) anos ou mais \\
2 Pinheiros & três (3) anos ou mais \\
3 Pátio Vila Sônia & três (3) anos ou mais \\
\hline
\end{tabular}

c) o Candidato gerou uma movimentação média anual, durante o período anterior, maior que a quantia declarada na Tabela (09 e 10) abaixo. A movimentação média anual é definida como o total de certificados de pagamento, certificados de trabalhos em progresso ou completados pela empresa ou empresas que incluem o Candidato, divididas pelo número de anos previamente informados ao Candidato.

Tabela 09 - Experiência geral, movimentação média anual referente a trabalhos civis.

\begin{tabular}{ll}
\hline (c1) Trabalhos Civis & \\
\hline Lote & Requerido montante médio anual \\
1 Paulista & US $\$ 130,000,000.00$ \\
2 Pinheiros & US $\$ 100,000,000.00$ \\
3 Pátio Vila Sônia & US $\$ 20,000,000.00$ \\
\hline
\end{tabular}

Tabela 10 - Experiência geral, movimentação média anual referente à instalação de equipamento e sistemas.

\begin{tabular}{ll}
\hline (c2) Instalação de Equipamento e Sistemas & \\
\hline Lote & Requerido montante médio anual \\
1 Paulista & US $\$ 25,000,000.00$ \\
2 Pinheiros & US $\$ 25,000,000.00$ \\
3 Pátio Vila Sônia & US $\$ 15,000,000.00$ \\
\hline
\end{tabular}


No caso de Joint Ventures/Consórcio o sócio no comando (o líder) é de trabalhos civis que tenha um montante anual maior que $40 \%$ das exigências do item (c1). Os outros sócios para os trabalhos civis devem ter um montante anual maior que $20 \%$ das exigências do item (c1). Cada sócio para instalação de equipamento e sistemas deve ter um montante anual maior que $15 \%$ da exigência do item (c2).

Em relação à experiência particular, o Candidato deve comprovar que alcançou a mínima produção mensal e/ou taxa anual das atividades de construção fundamentais e que completou prosperamente ou substancialmente o número de contratos, de natureza, complexidade, e tecnologia de provisão semelhante ao proposto Contrato.

Em relação a experiências particulares, referentes ao número exigido de contratos semelhantes completados e taxa de produção, tem-se:

a) o Candidato comprovará que completou trabalhos civis prosperamente, como um contratante principal ou como um parceiro de uma Joint Venture/Consórcio, como segue (Tabela 11):

Tabela 11 - Experiência particular, trabalhos civis.

\begin{tabular}{|c|c|c|c|c|}
\hline \multirow{6}{*}{ Lote 1 Paulista } & $\begin{array}{l}\text { Trabalhos Prosperamente } \\
\text { Completados }\end{array}$ & $\begin{array}{ll}\text { Quantidades } & \text { ou } \\
\text { Características } & \end{array}$ & Período (Anos) & $\begin{array}{l}\text { Número de } \\
\text { Contratos }\end{array}$ \\
\hline & $\begin{array}{l}\text { Escavação de túnel em Shield } \\
\text { com seção mínima de corte = } \\
25 \mathrm{~m}^{2}\end{array}$ & $22000 \mathrm{~m}^{3}$ & 20 & 1 \\
\hline & $\begin{array}{l}\text { Escavação de túneis em } \\
\text { NATM em área urbana }\end{array}$ & $60000 \mathrm{~m}^{3}$ & 20 & 1 \\
\hline & $\begin{array}{l}\text { Estação subterrânea em área } \\
\text { urbana }\end{array}$ & $9000 \mathrm{~m}^{2}$ & 20 & 1 \\
\hline & Concreto projetado em túnel & $6000 \mathrm{~m}^{3}$ & 20 & 1 \\
\hline & Serviços de concreto estrutural & $40000 \mathrm{~m}^{3}$ & 20 & 1 \\
\hline \multirow{5}{*}{$\begin{array}{l}\text { Lote } 2 \\
\text { Pinheiros }\end{array}$} & $\begin{array}{l}\text { Escavação de túnel em Shield } \\
\text { com seção mínima de corte = } \\
25 \mathrm{~m}^{2}\end{array}$ & $22000 \mathrm{~m}^{3}$ & 20 & 1 \\
\hline & $\begin{array}{l}\text { Escavação de túneis em } \\
\text { NATM em área urbana }\end{array}$ & $25000 \mathrm{~m}^{3}$ & 20 & 1 \\
\hline & $\begin{array}{l}\text { Estação subterrânea em área } \\
\text { urbana }\end{array}$ & $9000 \mathrm{~m}^{2}$ & 20 & 1 \\
\hline & Concreto projetado em túnel & $4000 \mathrm{~m}^{3}$ & 20 & 1 \\
\hline & Serviços de concreto estrutural & $20000 \mathrm{~m}^{3}$ & 20 & 1 \\
\hline \multirow{5}{*}{$\begin{array}{l}\text { Lote } 3 \text { Pátio } \\
\text { Vila Sônia }\end{array}$} & $\begin{array}{l}\text { Serviços em } \quad \text { concreto } \\
\text { estrutural para edificações }\end{array}$ & $5500 \mathrm{~m}^{3}$ & 20 & 1 \\
\hline & Serviços de escavação & $180000 \mathrm{~m}^{3}$ & 20 & 1 \\
\hline & Trabalhos em estradas & $1000 \mathrm{~m}$ & 20 & 1 \\
\hline & $\begin{array}{l}\text { Plantas ou Fábricas ou } \\
\text { Edifícios Industriais }\end{array}$ & $7000 \mathrm{~m}^{2}$ & 20 & 1 \\
\hline & $\begin{array}{l}\text { Estrada férrea ou construção } \\
\text { de pátio de manutenção de } \\
\text { metrô (área do pátio) }\end{array}$ & $30000 \mathrm{~m}^{2}$ & 20 & 1 \\
\hline
\end{tabular}


No caso de Joint Venture/Consórcio o parceiro no comando (o líder) comprova a capacidade de fornecer pelo menos $40 \%$ da experiência particular requerida no item (a).

b) O Candidato fornece experiência, próspera, na execução, como um contratante principal ou como um sócio em uma Joint Venture/Consórcio, no gerenciamento de provisão e na instalação de sistemas, de natureza e complexidade comparável aos contratos propostos. Esta experiência também pode ser provida na execução, como contratante administrador, como um fornecedor ou como um fabricante, na execução do gerenciamento de provisão e instalação de sistemas. A natureza e complexidade, referidas para a experiência exigida para cada lote, está definida na Tabela 12: 
Tabela 12 - Experiência particular, provisão e instalação de sistemas.

\begin{tabular}{|c|c|c|c|c|c|}
\hline \multirow{7}{*}{$\begin{array}{l}\text { Lote } 1 \\
\text { Paulista }\end{array}$} & \multicolumn{2}{|c|}{ Serviços Concluídos com Sucesso } & Características ou Quantidades & $\begin{array}{l}\text { Período } \\
\text { (Anos) }\end{array}$ & $\begin{array}{l}\text { № de } \\
\text { Contratos }\end{array}$ \\
\hline & \multicolumn{2}{|c|}{$\begin{array}{l}\text { Subestação de energia de voltagem } \\
\text { média AC }\end{array}$} & $\begin{array}{l}2 \text { subestações, classe de voltagem mínima } 25 \\
\mathrm{kV} \text {, com microprocessador de proteção } \\
\text { baseado em relés }\end{array}$ & 15 & 1 \\
\hline & \multicolumn{2}{|c|}{$\begin{array}{l}\text { Metrô ou estrada de ferro, subestação } \\
\text { retificadora DC baseada em diodo ou } \\
\text { elementos de thyristor }\end{array}$} & $\begin{array}{l}2 \text { subestações retificadoras com taxa de } \\
\text { voltagem de } 750 \text { a } 3000 \text { Vdc, energia mínima } \\
\text { de } 3 \mathrm{MW} \text {, classe "tração pesada" ou superior }\end{array}$ & 15 & 1 \\
\hline & \multicolumn{2}{|c|}{$\begin{array}{l}\text { Baixo sistema de distribuição de } \\
\text { voltagem incluindo painel de } \\
\text { transformadores e iluminação }\end{array}$} & $\begin{array}{l}\text { Uma instalação para Mass transit ou para } \\
\text { planta de energia elétrica ou para aplicação } \\
\text { industrial }\end{array}$ & 10 & 1 \\
\hline & \multicolumn{2}{|c|}{$\begin{array}{l}\text { Sistema de catenária rígida de energia } \\
\text { de } 750 \text { até } 3000 \text { Vdc ou sistema de } \\
\text { tensão automático }\end{array}$} & 4 km (caminho duplo) & 15 & 1 \\
\hline & $\begin{array}{l}\text { Sistemas de } \\
\text { telecomunicações }\end{array}$ & $\begin{array}{l}\text { Comunicações } \\
\text { permanentes }\end{array}$ & $\begin{array}{l}\text { PABX com pelo menos } 600 \text { extensões e } \\
\text { Cabeamento de pelo menos } 600 \text { pontos de } \\
\text { acesso para Mass transit ou aplicação da } \\
\text { planta de energia elétrica. }\end{array}$ & 10 & 1 \\
\hline & & Multimídia & $\begin{array}{l}\text { Sistema de Endereço Público e Sistema de } \\
\text { cronometria para Mass transit ou aplicação da } \\
\text { planta de energia elétrica }\end{array}$ & 10 & 1 \\
\hline \multirow{7}{*}{$\begin{array}{l}\text { Lote } 2 \\
\text { Pinheiros }\end{array}$} & \multicolumn{2}{|c|}{$\begin{array}{l}\text { Subestação de energia primaria de } \\
\text { alta voltagem }\end{array}$} & $\begin{array}{l}1 \text { subestação primaria, classe de voltagem } \\
\text { mínima } 69 \mathrm{kV} \text {, energia mínima de } 15 \mathrm{MVA} \\
\text { com microprocessador de proteção baseado } \\
\text { em relés }\end{array}$ & 15 & 1 \\
\hline & \multicolumn{2}{|c|}{$\begin{array}{l}\text { Subestação de energia de voltagem } \\
\text { média AC }\end{array}$} & $\begin{array}{l}2 \text { subestações, classe de voltagem mínima } 25 \\
\mathrm{kV} \text {, com microprocessador de proteção } \\
\text { baseado em relés }\end{array}$ & 15 & 1 \\
\hline & \multicolumn{2}{|c|}{$\begin{array}{l}\text { Metrô ou estrada de ferro, subestação } \\
\text { retificadora DC baseada em diodo ou } \\
\text { elementos de thyristor }\end{array}$} & $\begin{array}{l}2 \text { subestações retificadoras com taxa de } \\
\text { voltagem de } 750 \text { a } 3000 \mathrm{Vdc} \text {, energia mínima } \\
\text { de } 3 \mathrm{MW} \text {, classe "tração pesada" ou superior }\end{array}$ & 15 & 1 \\
\hline & \multicolumn{2}{|c|}{$\begin{array}{lll}\text { Baixo sistema de distribuição } & \text { de } \\
\text { voltagem incluindo painel } & \text { de } \\
\text { transformadores e iluminação } & \\
\end{array}$} & $\begin{array}{l}\text { Uma instalação para Mass transit ou para } \\
\text { planta de energia elétrica ou para aplicação } \\
\text { industrial }\end{array}$ & 10 & 1 \\
\hline & \multicolumn{2}{|c|}{$\begin{array}{l}\text { Sistema de catenária rígida de energia } \\
\text { de } 750 \text { até } 3000 \text { Vdc ou sistema de } \\
\text { tensão automático }\end{array}$} & 4 km (caminho duplo) & 15 & 1 \\
\hline & $\begin{array}{l}\text { Sistemas de } \\
\text { telecomunicações }\end{array}$ & $\begin{array}{l}\text { Comunicações } \\
\text { permanentes }\end{array}$ & $\begin{array}{l}\text { PABX com pelo menos } 400 \text { extensões e } \\
\text { Cabeamento de pelo menos } 400 \text { pontos de } \\
\text { acesso para Mass transit ou aplicação de } \\
\text { planta de energia elétrica. }\end{array}$ & 10 & 1 \\
\hline & & Multimídia & $\begin{array}{l}\text { Sistema de Endereço Público e Sistema de } \\
\text { cronometria para Mass transit ou aplicação da } \\
\text { planta de energia elétrica }\end{array}$ & 10 & 1 \\
\hline \multirow{6}{*}{$\begin{array}{l}\text { Lote } 3 \\
\text { Pátio Vila } \\
\text { Sônia }\end{array}$} & \multicolumn{2}{|c|}{$\begin{array}{l}\text { Subestação de energia de voltagem } \\
\text { média AC }\end{array}$} & $\begin{array}{l}2 \text { subestações, classe de voltagem mínima } 25 \\
\mathrm{kV} \text {, com microprocessador de proteção } \\
\text { baseado em relés }\end{array}$ & 15 & 1 \\
\hline & \multicolumn{2}{|c|}{$\begin{array}{l}\text { Metrô ou estrada de ferro, subestação } \\
\text { retificadora DC baseada em diodo ou } \\
\text { elementos de thyristor }\end{array}$} & $\begin{array}{l}1 \text { subestação retificadora com taxa de } \\
\text { voltagem de } 750 \text { a } 3000 \mathrm{Vdc} \text {, energia mínima } \\
\text { de } 3 \mathrm{MW} \text {, classe "tração pesada" ou superior }\end{array}$ & 15 & 1 \\
\hline & \multicolumn{2}{|c|}{$\begin{array}{l}\text { Baixo sistema de distribuição de } \\
\text { voltagem incluindo painel de } \\
\text { transformadores e iluminação }\end{array}$} & $\begin{array}{l}\text { Uma instalação para Mass transit ou para } \\
\text { planta de energia elétrica ou para aplicação } \\
\text { industrial }\end{array}$ & 10 & 1 \\
\hline & \multicolumn{2}{|c|}{$\begin{array}{l}\text { Sistema de catenária rígida de energia } \\
\text { de } 750 \text { até } 3000 \text { Vdc ou sistema de } \\
\text { tensão automático }\end{array}$} & $4 \mathrm{~km}$ (caminho duplo) & 15 & 1 \\
\hline & \multirow[t]{2}{*}{$\begin{array}{l}\text { Sistemas de } \\
\text { telecomunicações }\end{array}$} & $\begin{array}{l}\text { Comunicações } \\
\text { permanentes }\end{array}$ & $\begin{array}{l}\text { PABX com pelo menos } 200 \text { extensões e } \\
\text { Cabeamento de pelo menos } 200 \text { pontos de } \\
\text { acesso para Mass transit ou aplicação da } \\
\text { planta de energia elétrica. }\end{array}$ & 10 & 1 \\
\hline & & Multimídia & $\begin{array}{l}\text { Sistema de Endereço Público e Sistema de } \\
\text { cronometria para Mass transit ou aplicação da } \\
\text { planta de energia elétrica }\end{array}$ & 10 & 1 \\
\hline
\end{tabular}


c) O Candidato, diretamente ou através do apontamento de um ou mais Subcontratantes Especialistas claramente identificado, deverá comprovar que concluiu prosperamente os projetos de trabalhos civis, projetos de sistemas e a implementação de estrada férrea (Tabela 13):

Tabela 13 - Experiência particular, projeto trabalhos civis e sistemas.

\begin{tabular}{|c|c|c|c|c|}
\hline \multirow{3}{*}{$\begin{array}{l}\text { Lote } 1 \text { Paulista } \\
\text { Trabalhos Civis }\end{array}$} & $\begin{array}{l}\text { Serviços Concluídos com } \\
\text { Sucesso }\end{array}$ & $\begin{array}{l}\text { Características } \\
\text { Quantidades }\end{array}$ & $\begin{array}{l}\text { Período } \\
\text { (Anos) }\end{array}$ & $\begin{array}{l}\text { Número de } \\
\text { Contratos }\end{array}$ \\
\hline & $\begin{array}{l}\text { Projeto de trabalhos civis } \\
\text { de túnel e/ou estações }\end{array}$ & $\begin{array}{l}\text { Por método não destrutivo, } \\
\text { em área urbana }\end{array}$ & 20 & 1 \\
\hline & $\begin{array}{l}\text { Implementação de estrada } \\
\text { férrea }\end{array}$ & $\begin{array}{l}\text { Incluindo sistema de } \\
\text { abafamento de vibração e } \\
\text { ruído }\end{array}$ & 20 & 1 \\
\hline \multirow{2}{*}{$\begin{array}{c}\text { Lote } 2 \\
\text { Pinheiros } \\
\text { Trabalhos Civis }\end{array}$} & $\begin{array}{l}\text { Projeto de trabalhos civis } \\
\text { de túnel e/ou estações }\end{array}$ & $\begin{array}{l}\text { Por método não destrutivo, } \\
\text { em área urbana }\end{array}$ & 20 & 1 \\
\hline & $\begin{array}{l}\text { Implementação de estrada } \\
\text { férrea }\end{array}$ & $\begin{array}{l}\text { Incluindo sistema de } \\
\text { abafamento de vibração e } \\
\text { ruído }\end{array}$ & 20 & 1 \\
\hline $\begin{array}{l}\text { Lote } 3 \\
\text { Pátio Vila Sônia } \\
\text { Trabalhos Civis }\end{array}$ & $\begin{array}{l}\text { Projeto de Metrô e/ou } \\
\text { trabalhos civis em estrada } \\
\text { férrea }\end{array}$ & & 20 & 1 \\
\hline \multirow[t]{2}{*}{$\begin{array}{l}\text { Lote } 1 \text { Paulista } \\
\text { Sistemas }\end{array}$} & $\begin{array}{l}\text { Projeto de instalações } \\
\text { eletromecânicas }\end{array}$ & $\begin{array}{l}\text { Abrangendo: Elétrico, } \\
\text { ocupação espacial de } \\
\text { cabos de iluminação, } \\
\text { itinerário dos cabos } \\
\text { (dutos/vias dos cabos) }\end{array}$ & 15 & 1 \\
\hline & $\begin{array}{l}\text { Projeto de instalações } \\
\text { hidráulicas }\end{array}$ & $\begin{array}{l}\text { Abrangendo: hidráulicos, } \\
\text { perfurar e imbutir }\end{array}$ & 15 & 1 \\
\hline \multirow[t]{2}{*}{$\begin{array}{c}\text { Lote } 2 \\
\text { Pinheiros } \\
\text { Sistemas }\end{array}$} & $\begin{array}{l}\text { Projeto de instalações } \\
\text { eletromecânicas }\end{array}$ & 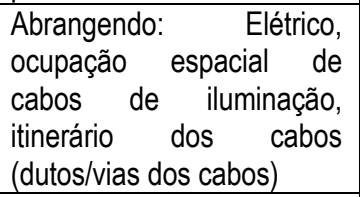 & 15 & 1 \\
\hline & $\begin{array}{l}\text { Projeto de instalações } \\
\text { hidráulicas }\end{array}$ & $\begin{array}{l}\text { Abrangendo: hidráulicos, } \\
\text { perfurar e imbutir }\end{array}$ & 15 & 1 \\
\hline \multirow[t]{2}{*}{$\begin{array}{l}\text { Lote } 3 \text { Pátio } \\
\text { Vila Sônia } \\
\text { Sistemas }\end{array}$} & $\begin{array}{l}\text { Projeto de instalações } \\
\text { eletromecânicas }\end{array}$ & 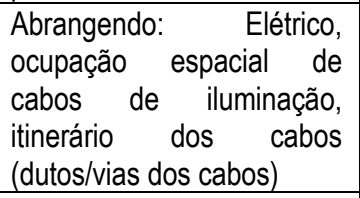 & 15 & 1 \\
\hline & $\begin{array}{l}\text { Projeto de instalações } \\
\text { hidráulicas }\end{array}$ & $\begin{array}{l}\text { Abrangendo: hidráulicos, } \\
\text { perfurar e embutir }\end{array}$ & 15 & 1 \\
\hline
\end{tabular}

As empresas de consultoria, na forma de sócio ou subcontratantes, têm que comprovar experiência de projeto por certificados emitidos no nome do profissional (como técnico responsável) pertencente ao Candidato ou ao pessoal do subcontratante.

Em relação à capacidade financeira, o Candidato deve demonstrar ter acesso ou ter ativos disponíveis, líquidos, ativos reais não onerados, linhas de crédito, e outros meios financeiros (independente de qualquer pagamento contratual de antemão) 
suficientes para satisfazer as exigências de fluxo monetário de construções requeridas no contrato(s), no caso de obstrução, atrasos ou outras demoras em pagamento, do mínimo da quantia estimada e declarada na tabela abaixo (Tabela 14).

Tabela 14 - Capacidade financeira.

\begin{tabular}{lc}
\hline Quantia mínima de ativos líquidos, ativos reais não onerados, linhas de crédito e outros meios financeiros. \\
\hline Lote & Fluxo Monetário de Construção \\
1 & US $\$ 40,000,000.00$ \\
2 & US $\$ 30,000,000.00$ \\
3 & US $\$ 10,000,000.00$ \\
\hline
\end{tabular}

O Candidato também deve comprovar para o Empregador, que têm fontes adequadas de finanças para satisfazer as exigências de fluxo monetário aos trabalhos e para compromissos de contrato de futuro.

Quanto a exame dos balancetes ou, se não requerido pelas leis do país do Candidato, outras demonstrações financeiras aceitáveis ao Empregador, durante os últimos cinco anos são submetidos e tem que demonstrar as boas condições financeiras atuais do Candidato e indicar sua rentabilidade em longo prazo. Se julgar necessário, o Empregador tem a autoridade para fazer investigações junto aos banqueiros do Candidato.

No que se refere à Capacidade Pessoal, o Candidato informa sobre a administração, estrutura da empresa e faz provisão de pessoal apropriadamente qualificado para preencher as posições fundamentais, como exigido à implementação do Contrato. O Candidato fornece informações sobre um candidato principal e um substituto para cada posição fundamental, ambos devem satisfazer as exigências de experiência (Tabela 15). 
Tabela 15 - Capacidade pessoal.

\begin{tabular}{|c|c|c|c|}
\hline & Posição & Graduação (anos) & $\begin{array}{l}\text { Experiência total em } \\
\text { trabalhos nesta posição } \\
\text { (anos) }\end{array}$ \\
\hline \multirow{5}{*}{$\begin{array}{l}\text { Lote } 1 \\
\text { Paulista }\end{array}$} & Gerente de projeto & quinze (15) & cinco (5) \\
\hline & Gerente de sistemas & doze (12) & cinco (5) \\
\hline & Gerente de trabalhos civis & doze (12) & quatro (4) \\
\hline & Chefe de produção & doze (12) & quatro (4) \\
\hline & Chefe de planejamento & doze (12) & quatro (4) \\
\hline \multirow{5}{*}{$\begin{array}{c}\text { Lote } 2 \\
\text { Pinheiros }\end{array}$} & Gerente de projeto & quinze (15) & cinco (5) \\
\hline & Gerente de sistemas & doze (12) & cinco (5) \\
\hline & Gerente de trabalhos civis & doze (12) & quatro (4) \\
\hline & Chefe de produção & doze (12) & quatro (4) \\
\hline & Chefe de planejamento & doze (12) & quatro (4) \\
\hline \multirow{5}{*}{$\begin{array}{c}\text { Lote } 3 \\
\text { Pátio Vila Sônia }\end{array}$} & Gerente de projeto & doze (12) & quatro (4) \\
\hline & Gerente de sistemas & Doze (12) & cinco (5) \\
\hline & Gerente de trabalhos civis & $\operatorname{dez}(10)$ & quatro (4) \\
\hline & Chefe de produção & $\operatorname{dez}(10)$ & quatro (4) \\
\hline & Chefe de planejamento & $\operatorname{dez}(10)$ & quatro (4) \\
\hline
\end{tabular}

Em relação à Operacionalização, o Contratante fornece e emprega, no local de implementação das instalações, todo o trabalho especializado, semi-especializado e não especializado, como necessário para a apropriada e oportuna execução do Contrato. $\mathrm{O}$ Contratante é incentivado a usar o trabalho local, com as necessárias habilidades, e é responsável pelo recrutamento, transporte, acomodação de todo o trabalhador, local ou expatriado, requeridos para a execução do Contrato e todos os pagamentos em conexão com este.

O Contratante deve durante o progresso do Contrato impedir condutas ilegais, tumultuosas ou comportamento desordenado, pelos seus empregados e pelo trabalho do seu Subcontratante.

Em relação a Capacidades de Equipamentos, o Candidato possui, ou assegura acesso (por contratação, lease, acordo de compra, outros meios comerciais ou subcontratando) a equipamentos-chave, (Tabela 16), e terá que demonstrar que, baseado em compromissos conhecidos, eles estariam disponíveis para uso oportuno no proposto Contrato. O Candidato também pode listar tipos alternativos de equipamento que proporia para uso no Contrato, junto com uma explicação da proposta. 
Tabela 16 - Capacidade de equipamentos.

\begin{tabular}{|c|c|c|c|}
\hline \multirow{11}{*}{$\begin{array}{l}\text { Lote } \\
\text { Paulista }\end{array}$} & \multicolumn{2}{|c|}{ Tipo de Equipamento e Características } & \multirow{2}{*}{$\begin{array}{l}\text { Número Mínimo } \\
\text { Requerido } \\
\text { um (1) }\end{array}$} \\
\hline & 1 & $\begin{array}{l}\text { Proteção para Equilíbrio da Pressão de Terra - EPBS, Slurry ou } \\
\text { semelhante, completo com equipamento auxiliar. }\end{array}$ & \\
\hline & 2 & Máquina de lançar concreto projetado, mista wet/dry & seis (6) \\
\hline & 3 & Planta de concreto projetado & seis (6) \\
\hline & 4 & Planta de ar comprimido para Shield (mínimo 3500 pcm) & um (1) \\
\hline & 5 & Guindaste rubber-tired (mínimo: $30 t$ ) & dois (2) \\
\hline & 6 & $\begin{array}{l}\text { Guindaste de canteiro levantamento elétrico e clam-shell } \\
\text { (extensão mínima: } 15 \mathrm{~m} \text {; capacidade: } 5,0 \mathrm{t} \text { ) }\end{array}$ & oito (8) \\
\hline & 7 & $\begin{array}{l}\text { Planta para segmentos de túnel linear de pré-lançamento } \\
\text { (capacidade de produção: mínimo vinte e cinco (25) anéis } \\
\text { completos por dia) }\end{array}$ & um (1) \\
\hline & 8 & Locomotiva elétrica (bateria) & seis (6) \\
\hline & 9 & Caminhão com andaime Pantógrafo & três (3) \\
\hline & 10 & Crawler Drill Ring & um (1) \\
\hline \multirow{11}{*}{$\begin{array}{l}\text { Lote } \\
\text { Pinheiros }\end{array}$} & 1 & $\begin{array}{l}\text { Maquina de Perfuração de Túnel - TBM (solo/rocha) } \\
\text { semelhante, completo com equipamento auxiliar }\end{array}$ & um (1) \\
\hline & 2 & Máquina de lançar concreto projetado, mista wet/dry & seis (6) \\
\hline & 3 & Planta de concreto projetado & seis $(6)$ \\
\hline & 4 & Planta de ar comprimido para Shield (mínimo 3500 pcm) & dois (2) \\
\hline & 5 & Guindaste rubber-tired (mínimo: 30t) & dois (2) \\
\hline & 6 & $\begin{array}{l}\text { Guindaste de canteiro levantamento elétrico e clam-shell } \\
\text { (extensão mínima: } 15 \mathrm{~m} \text {; capacidade: } 5,0 \mathrm{t} \text { ) }\end{array}$ & oito (8) \\
\hline & 7 & $\begin{array}{l}\text { Planta para segmentos de túnel linear de pré-lançamento } \\
\text { (capacidade de produção: mínimo vinte e cinco (25) anéis } \\
\text { completos por dia) }\end{array}$ & um (1) \\
\hline & 8 & Locomotiva elétrica (bateria) & seis (6) \\
\hline & 9 & Caminhão com andaime Pantógrafo & três (3) \\
\hline & 10 & Crawler Drill Ring & um (1) \\
\hline & 11 & Hydromill ou hydrosfresa para parede de diafragma & dois (2) \\
\hline \multirow{5}{*}{$\begin{array}{l}\text { Lote } 3 \text { Pátio } \\
\text { Vila Sônia }\end{array}$} & 1 & Rolo pé de cabra vibratória & dois (2) \\
\hline & 2 & Carregador rubber-tired $170 \mathrm{HP}$ & quatro (4) \\
\hline & 3 & Crawler back-hoe & dois (2) \\
\hline & 4 & Escavadora $335 \mathrm{HP}$ & dois (2) \\
\hline & 5 & Rematador vibratório de asfalto & um (1) \\
\hline
\end{tabular}

Quanto ao Equipamento e Sistemas, o Contratante deve fabricar ou obter e transportar todos os Equipamentos e Sistemas, de maneira ordenada e planejada, ao Canteiro de Obra. O Contratante deve a seus próprios riscos e despesas, transportar todos os Equipamentos e Sistemas ao Canteiro de Obras pela modalidade de transporte que julgar mais apropriada. O Contratante é o responsável pela obtenção de aprovações das autoridades, se necessárias, para o transporte dos equipamentos e dos sistemas ao local da Obra. O Empregador deve ajudar o Contratante a obter tais aprovações, requisitadas.

Diante da expedição de carregamentos com equipamento e sistemas, o Contratante notifica o Empregador da descrição do equipamento e sistemas, o ponto e os meios da expedição, e a época estimada e o ponto da chegada no país. 
Quando estabelecido no Acordo de Contrato, o Empregador deve prover itens específicos de maquinário, equipamentos ou materiais ao Contratante, por conta e risco, transportar cada item ao Canteiro de Obra ou nas proximidades, assim como acordado entre as partes, de forma a tornar tal item disponível no momento determinado e programado pelo Contratante. A despeito dos itens recebidos, o Contratante deve visualmente inspecioná-los e notificar o Gerente de Projeto de toda escassez ou defeito detectado. O Empregador resolve tal escassez ou defeito, ou o Contratante deve, se praticável e possível, no pedido do Empregador, resolver tal falta, defeito aos custos e despesas do Empregador. Após a inspeção, tal artigo fica sob o cuidado, custódia e controle do Contratante.

O Candidato proverá informação sobre qualquer litígio ou arbitragem que resultou de contratos dos últimos cinco anos. Caso o Candidato ou qualquer sócio de uma Joint Venture/Consórcio tenha sido condenado em uma sentença anterior, isso pode resultar em impedimento da candidatura.

\subsubsection{Joint Ventures/Consórcio}

A Joint Venture/Consórcio tem que satisfazer os critérios de qualificação coletivamente. Para este propósito podem ser somados os dados seguintes de cada sócio da Joint Venture/Consórcio para atender os critérios qualificativos coletivos já apresentados nas tabelas anteriores: montante médio anual e a taxa fundamental de produção, fluxo monetário de construção, experiência particular, capacidades de pessoal e capacidades de equipamento.

Cada sócio tem que satisfazer os critérios seguintes individualmente:

a) experiência geral para o período de anos declarados (Tabelas 07 e 08);

b) fontes adequadas para atender compromissos financeiros em outros contratos;

c) bom estado financeiro (exame de balancete); e

d) histórico de litígio.

Um dos sócios que é responsável pela execução de uma função fundamental do Contrato ou que está executando um componente principal do Contrato é nomeado para o comando durante o período de pré-qualificação e licitação e, eventualmente, durante execução de Contrato. O sócio no comando está autorizado a adquirir responsabilidades e receber instruções, para e em nome de qualquer dos sócios da Joint 
Venture/Consórcio, submetendo uma procuração assinada por signatários legalmente autorizados de todos os sócios.

Todos os sócios da Joint Venture/Consórcio são, juntamente e individualmente, legalmente responsáveis durante o processo de licitação e para a execução do Contrato, conforme as condições de contrato.

Quanto ao Acordo de Joint Venture/Consórcio, uma cópia do Acordo de Joint Venture/Consórcio (JVA) entre os sócios é submetida com a candidatura. O JVA inclui entre outras coisas: os objetivos da JV; a estrutura de administração proposta; a contribuição de cada sócio para as operações da Joint Venture/Consórcio; o compromisso do sócio com as responsabilidades para o devido desempenho, tanto do conjunto como individual; recursos/sanções dentro do JV no caso de falta ou retirada de qualquer sócio e; arranjos para prover as indenizações exigidas.

\subsubsection{O entendimento nas disputas}

A Comissão Examinadora de Disputas - Dispute Review Board (DRB) - é uma comissão de três membros selecionados e que agem de acordo com as regras e os procedimentos definidos no Contrato para procurar resolver todo tipo de disputa que surgir entre o Empregador e o Contratante tendo relação ou não com o Contrato (se os partidos não resolverem tal disputa ou diferença pela consulta mútua), incluindo as que genericamente não causam prejuízo ao Contrato.

A Comissão é composta por três membros experientes com o tipo de construção e serviços envolvidos no Contrato e com a interpretação dos documentos contratuais. Tanto o Empregador quanto o Contratante devem selecionar um membro que será submetido à aprovação da outra parte. O terceiro membro será selecionado pelos outros dois e aprovado pelas partes, ele servirá como o presidente da Comissão.

Não obstante a alguma referência à Comissão ou a Arbitragem:

(a) as partes continuam a executar as suas respectivas obrigações diante o Contrato, a menos que acordado de outra maneira.

(b) o Empregador paga ao Contratante todo o dinheiro devido a este.

\subsubsection{Responsabilidades do Contratante}

O Contratante deve projetar, executar e terminar os trabalhos e, solucionar os defeitos de acordo com as provisões do Contrato. O Contratante fornece toda a superintendência, trabalhos, materiais, plantas, equipamentos e todo o restante, de 
natureza provisório ou permanente, requeridos para tais projetos, execução, conclusão e solucionar defeitos, tanto quanto o necessário para fornecer o especificado no Contrato ou o razoável para inferi-lo Contrato.

O Contratante assume a responsabilidade pela adequação, estabilidade e segurança de todas as operações no local da Obra e métodos de construção, não sendo responsável (exceto indicação contrária) pelo projeto ou especificação de qualquer trabalho permanente ou provisório, não realizado pelo Contratante. O Gerente de Projeto verifica o trabalho do Contratante e notificam todos os defeitos que forem encontrados. Tal verificação não afeta as responsabilidades do Contratante. O Gerente de Projeto pode instruir o Contratante a procurar por um defeito, descobri-lo e testar todo o trabalho que considerar defeituoso.

O Contratante confirma que participou, na base do Contrato, de um exame apropriado dos dados que se relacionam às Instalações, fornecidos pelo Empregador, e na base das informações que o Contratante poderia ter obtido de uma inspeção visual do Local (se disponível) e de outros dados prontamente disponíveis a ele que se relaciona às Instalações até vinte e oito (28) dias antes da data submissão da oferta. Deste modo, reconhecendo que qualquer falha em familiarizar-se com tais dados e informações não alivia sua responsabilidade para com a correta estimativa da dificuldade ou o custo de execução das Instalações, com sucesso.

O Contratante adquire, em seu nome, todas as permissões, aprovações e/ou licenças de toda a autoridade local, do país da Obra, que são necessárias para o desempenho do Contrato, incluindo, sem limitação, os vistos para o pessoal do Contratante e do Subcontratante e as licenças de entrada para todo o equipamento importado do Contratante.

O Contratante cumpre com todas as forças de leis do país onde as Instalações são implementadas e onde os Serviços de Instalação são realizados, incluindo todas as leis locais, estaduais, nacionais ou outras (CIPA, engenharia de segurança e medicina do trabalho, etc...) que afetem o desempenho ligado ao Contrato e ao Contratante. O Contratante indeniza e isenta o Empregador de todas as responsabilidades, danos, reivindicações, multas, penalidades e despesas, de qualquer natureza, que levantar ou resultar da violação de tais leis, pelo Contratante ou seu pessoal, incluindo os Subcontratantes e seu pessoal. 


\subsubsection{Responsabilidades do Empregador}

O Empregador deve assegurar a exatidão de todas as informações e/ou dados a serem fornecidas por ele ao Contratante a não ser quando indicado de outra maneira no Contrato.

O Empregador deve ser responsável por adquirir e providenciar a posse legal e física do Local de obra e acessos a ele, e por providenciar a posse de acessos a todas as áreas requeridas à apropriada execução do Contrato.

O Empregador adquire e paga por todas as permissões, aprovações e/ou licenças de toda a autoridade local, do país da Obra, que são necessários para o desempenho do Contrato, quando especificadas no Acordo de Contrato.

Se requisitado pelo Contratante, o Empregador o ajuda, na obtenção, de maneira oportuna e rápida, de todas as permissões aprovações e/ou licenças necessárias à execução do Contrato.

\subsubsection{Impostos e deveres}

Exceto quando indicado de outra forma no Contrato, o Contratante deve arcar e pagar todos os impostos, deveres, tarifas e cargas avaliados ao Contratante, seus Subcontratantes ou seus empregados, pelas autoridades dos governos municipais, estaduais ou nacionais em relação às Instalações, dentro e fora do país onde a Obra está locada.

Se alguma isenção, redução, permissão ou privilégio de imposto puderem estar disponível ao Contratante, no país da Obra, o Empregador deve usar seus melhores esforços a permitir que o Contratante se beneficie desta economia do montante de impostos.

\subsubsection{Propriedade intelectual}

O copyright em todos os desenhos, documentos e em outros materiais contendo dados e informação fornecida ao Empregador pelo Contratante, remanescerá investido no Contratante ou se forem fornecidos ao Empregador diretamente ou através do Contratante por qualquer terceira parte, incluindo fornecedores dos materiais, o copyright de tais materiais remanescerá investido em tal terceira parte.

O Empregador e o Contratante são mantidos confidenciais e não devem, sem o consentimento escrito da outra parte, divulgar a nenhuma terceira parte quaisquer originais, dados ou outras informações fornecidas diretamente ou indiretamente pela 
outra parte em relação ao Contrato, se tal informação foi fornecida antes, durante ou depois do término do Contrato. A despeito do acima, o Contratante pode fornecer a seu Subcontratante(s) tais documentos, dados e outras informações que receber do Empregador, requeridos para que o Subcontratante(s) possa executar seu trabalho sob o Contrato, em tal evento o Contratante obterá de tal Subcontratante(s) um empenho de confidencia similar ao imposto a ele pelo Empregador.

Tanto o Empregador quanto a Concessionária não usarão documentos, dados e outras informações recebidas do Contratante para qualquer finalidade à exceção da operação e da manutenção das Instalações. Similarmente, o Contratante não usará tais documentos, dados e outras informações recebidas do Empregador para nenhuma finalidade à exceção do projeto, a obtenção de equipamento e sistemas, da construção ou outros trabalhos e serviços requeridos para o desempenho do Contrato.

\subsubsection{Execução das Instalações}

O Contratante fornece ao Empregador e ao Gerente de Projeto uma carta que mostra a organização/programação (a exemplo do Programa de Execução do Lote 1 da Linha 4 - Amarela do Metrô, apresentado no Anexo A) da proposta a ser estabelecida por ele para realizar o trabalho nas Instalações. A carta inclui as identidades e currículos do pessoal chave a ser empregado. O Contratante informa prontamente o Empregador e o Gerente de Projeto, por escrito, toda a revisão ou alteração de tal carta de organização/programação.

Dentro de vinte e oito (28) dias, após a data de assinatura do Acordo de Contrato, o Contratante prepara e submete ao Gerente de Projeto um programa detalhado do desempenho do Contrato, feito em formulário especificado e mostrando a seqüência em que propõe projetar, construir, manufaturar, transportar, montar, instalar e pré-delegar as Instalações, tanto quanto a data pela qual o Contratante requer que o Empregador cumpra suas obrigações sob o Contrato, a fim de permitir a execução do Contrato de acordo com o programa e alcançar a Conclusão, Delegação e a Aceitação das Instalações. O Contratante atualiza e revisa o programa, como e quando apropriado ou quando requerida pelo Gerente de Projeto, mas sem modificação nos Tempos para a Conclusão determinados e toda a extensão de tempo concedida, submetendo todas estas revisões ao Gerente de Projeto.

O Contratante monitora o progresso de todas as atividades especificadas no programa acima referido e fornece um relatório de progresso ao Gerente de Projeto todo 
mês, indicando: (a) a porcentagem da conclusão alcançada, comparada com a porcentagem de conclusão planejada para cada atividade; e (b) onde há alguma atividade atrasada, em relação ao programa, dando comentários e conseqüências prováveis e indicando a ação corretiva a ser tomada.

Se a qualquer momento o progresso real do Contratante falhar, diante do programa acima referido ou aparentar que irá falhar, o Contratante deve, no pedido do Empregador ou do Gerente de Projeto, preparar e submeter ao Gerente de Projeto um programa revisado levando em conta as circunstâncias predominantes, e notificará o Gerente de Projeto das etapas que estão sendo tomadas para apressar o progresso com o objetivo de alcançar a Conclusão das Instalações dentro do Tempo para Conclusão ou toda extensão de tempo concedida de forma acordada entre o Empregador e o Contratante.

O Contrato deve ser executado de acordo com sua documentação e com os procedimentos das Especificações Técnicas. O Contratante pode executar o Contrato de acordo com seus próprios padrões de projeto, planos de execução e procedimentos até o ponto em que não se opõem às provisões contidas no Contrato.

Uma proposta de Plano de Garantia da Qualidade, para trabalhos civis e sistemas, deve ser submetida à aprovação do Empregador pelo Contratante.

No que tange o projeto e a engenharia, o Contratante executa o detalhamento de projeto e o trabalho de engenharia em conformidade com as provisões do Contrato, ou onde não assim especificado, de acordo com a boa prática da engenharia.

O Contratante é responsável por todas as discrepâncias, erros ou omissões, nas especificações, desenhos e outros documentos técnicos que tenha preparado, aprovado ou não pelo Gerente de Projeto, contanto que tais discrepâncias, erros ou omissões não forem resultado de inexatas informações fornecidas por escrito ao Contratante pelo Empregador ou em seu nome.

O Contratante tem o direito a negar a responsabilidade por qualquer projeto, dados, desenho, especificação ou outro documento, ou toda a modificação nestes, fornecida ou designada pelo Empregador ou em seu nome, notificando o Gerente de Projeto de tal negação.

O Empregador e o Contratante devem estabelecer os regulamentos do local da Obra, através de regras a serem observadas na execução do Contrato (como regras no respeito da segurança, segurança das instalações, controle de porta, sanitária, cuidado médico, prevenção ao fogo e outras). 
O Contratante deve executar seu trabalho de modo a minimizar, à extensão possível, interferência com o trabalho de outros Contratantes. O Contratante notificará prontamente o Gerente de Projeto de quaisquer defeitos no trabalho dos outros Contratantes que vierem a sua observação, e que poderia afetar o seu trabalho. $O$ Gerente de Projeto determina as medidas corretivas, se existirem, requeridas para retificar a situação após a inspeção das Instalações.

Se houver alguma emergência, que possa causar danos às Instalações, o Contratante deve interceder de forma corretiva imediata. Caso o Contratante seja incapaz ou relutante de realizar, imediatamente, tal trabalho, o Empregador pode fazer com que tal trabalho seja feito, a fim de impedir os danos às Instalações.

No curso de execução do Contrato, o Contratante mantém o local razoavelmente livre de toda a obstrução desnecessária, armazena ou remove todos os materiais em excesso. Após a conclusão de todas as partes das Instalações, o Contratante deve limpar, completamente, a obra.

O Contratante fornece e mantém, sob sua despesa, toda iluminação, cerca e guarnições, quando e onde for necessário para a execução e proteção das Instalações, ou para a segurança dos ocupantes das Instalações, propriedade adjacente e segurança do público. Além disso, o Contratante realiza os estudos requeridos de avaliação do impacto ambiental, para com os padrões ambientais definidos nas Especificações Técnicas e de forma a realizar os trabalhos e os serviços de acordo com as recomendações destes estudos. Deste modo, o Contratante segue todas as etapas razoáveis para proteger o ambiente dentro e fora do local da Obra, para evitar os danos ou incômodo às pessoas, à propriedade do público ou de outros, que resulte da poluição, do ruído ou outras causas que sejam em conseqüência de seus métodos de trabalho.

Todos os testes e/ou inspeções dos equipamentos, dos sistemas e de qualquer parte das Instalações, como especificado no Contrato, deve se realizar no local de manufatura e/ou no local da Obra, pelo Contratante, sob suas despesas.

O Gerente de Projeto pode requerer que o Contratante realize testes e/ou inspeções não requeridas pelo Contrato, contanto que os incorridos custos e despesas em realizá-los, sejam adicionados ao Valor do Contrato. Se tais testes e/ou inspeções impedirem o progresso do trabalho nas Instalações e/ou o desempenho do Contratante diante de outras obrigações sob o Contrato, a avaliação de alterações no Tempo para Conclusão do Contrato, deve ser feita em respeito ao Contratante e suas outras obrigações. 
Se, algum equipamento, sistema ou qualquer parte das Instalações não passarem em algum teste e/ou inspeção, o Contratante retifica ou substitui tal equipamento e sistemas ou parte das Instalações e repete o teste e/ou a inspeção.

Em todo teste, o Gerente de Projeto promove a cooperação e a coordenação entre o Contratante e o Empregador, diretamente ou através da Concessionária, de modo a conseguir a maior participação possível do Empregador em tais testes, para que futuramente se obtenha uma agradável operação das Instalações.

\subsubsection{Conclusão das Instalações}

Assim que as Instalações ou qualquer parte delas tiverem, na opinião do Contratante, operacionalmente e estruturalmente completas e em conformidade com as Especificações Técnicas, excluindo itens menores que não afetam, materialmente, a operação ou a segurança das Instalações, o Contratante deve, assim, notificar o Empregador por escrito, para que, dentro de sete dias, o Empregador forneça o pessoal operacional e de manutenção, as matérias primas, utilidades, lubrificantes, produtos químicos, catalisadores, facilidades, serviços e outras matérias requeridas á Prédelegação ${ }^{26}$ das Instalações ou de qualquer parte delas, em conformidade com o Acordo de Contrato.

Assim que, todos os trabalhos, no respeito da Pré-delegação forem terminados e, na opinião do Contratante, as Instalações ou qualquer parte delas estiverem prontas para a Delegação, o Contratante deve notificar o Gerente de Projeto por escrito. Se, o Contratante, for notificado de defeitos e/ou deficiências, pelo Gerente de Projeto, deverá corrigir tais defeitos e/ou deficiências e repetir a notificação por escrito. Caso o Gerente de Projeto determine que as Instalações ou que parte delas alcançaram a Conclusão, o mesmo deve, dentro de um prazo pré-estabelecido, emitir um certificado de conclusão para tais Instalações ou partes delas em questão.

Após a conclusão, o Contratante termina todos os itens menores proeminentes, $o$ mais cedo possível, de modo que as Instalações estejam inteiramente de acordo com as exigências do Contrato. No caso do Contratante falhar, o Empregador pode empreender tal conclusão e deduzir os custos desta do montante devido ao mesmo.

\footnotetext{
26 Pré-delegar (Pre-commissioning) significa testar, verificar e, outras exigências especificadas nas Especificações Técnicas que devem ser realizadas pelo Contratante na preparação da Delegação (Commissioning). Delegação significa a operacionalização das Instalações ou qualquer parte dela, pelo Contratante, depois da Conclusão, a fim de cumprir os Testes de Garantia.
} 
Diante da Conclusão, o Empregador, diretamente ou através da Concessionária, será responsável pelos cuidados e custódia das Instalações ou da parte relevante delas, juntamente com os riscos de perdas ou de danos a elas.

Durante a Delegação das Instalações ou da parte relevante delas, o teste de garantia deve ser conduzido pelo Contratante, para verificar se elas podem alcançar as garantias funcionais especificadas nas Especificações Técnicas. O Empregador, diretamente ou através da Concessionária, fornece pessoal operacional e da manutenção e todas as matérias primas, as utilidades, os lubrificantes, os produtos químicos, os catalisadores, as facilidades, os serviços e outras matérias requeridas para Delegação.

O Gerente de Projeto e o Representante do Empregador, diretamente ou através do Representante da Concessionária, promovem a cooperação e a coordenação dos testes de garantia das Instalações.

A aceitação operacional ocorre, no respeito das Instalações ou parte delas, quando:

a) o teste de garantia foi concluído com sucesso e as garantias funcionais foram alcançadas, ou;

b) o teste da garantia não foi concluído com sucesso nem realizado com sucesso, por razões não atribuídas ao Contratante, ou;

c) o Contratante pagou a liquidação dos danos, e;

d) todos os itens menores mencionados, relevantes as Instalações ou parte delas, foram concluídos.

Após os eventos, acima listados, terem ocorrido, o Contratante pode notificar o Gerente de Projeto, requisitando o certificado de aceitação operacional, no respeito das Instalações ou das partes delas especificadas. Devendo, o Gerente de Projeto, dentro de sete dias da notificação do Contratante, emitir um Certificado de Aceitação Operacional ou Parcial Aceitação.

\subsubsection{Garantias e responsabilidades}

O Contratante garante que alcançará a conclusão das Instalações ou uma parte delas, em acordo com o Tempo para Conclusão (Time for Completion) pré-estabelecido ou dentro do prolongamento deste tempo, acordado entre as partes. Porém, se o Contratante não alcançar a conclusão das Instalações ou qualquer parte delas, dentro do Tempo para Conclusão ou de qualquer prolongamento deste, o Contratante paga ao Empregador a liquidação dos danos, na quantidade especificada como uma taxa da 
porcentagem do Valor do Contrato ou da parte relevante. A quantidade agregada de tais danos liquidados, em nenhum evento excede a quantidade pré-especificada como o "máximo". Uma vez que o "máximo" é atingido, o Empregador pode considerar o termino do Contrato. O pagamento da liquidação dos danos, de forma nenhuma, aliviará o Contratante de outras obrigações e responsabilidades para com o Contrato, ou seja, não o isenta de suas responsabilidades sobre o não cumprimento de metas estabelecidas, perdas e danos relacionados, sofridos pelo Empregador.

Por outro lado, se o Contratante alcança a conclusão das Instalações ou qualquer parte delas, antes do término do Tempo para Conclusão ou do prolongamento deste, o Empregador pagará ao Contratante um bônus, na quantidade pré-especificada. A quantidade agregada de tal bônus, em nenhum momento, excederá a quantidade préespecificada como o "máximo".

O Contratante deve garantir que as Instalações ou qualquer parte delas estarão livres de defeitos no projeto, na engenharia, nos materiais, da mão de obra empregada nos equipamentos e sistemas fornecidos e do trabalho executado. O período de responsabilidade pelo defeito será de dezoito (18) meses da data da Conclusão das Instalações (ou de qualquer parte dela), ou doze (12) meses da data da Aceitação Operacional das Instalações (ou de qualquer parte dela), qual ocorrer primeiro. Se durante o período de responsabilidade pelo defeito, algum defeito for encontrado no projeto, na engenharia, nos materiais e na mão de obra dos equipamentos e dos sistemas fornecidos ou do trabalho executado pelo Contratante, ele, sob seus custos, deve prontamente, consultando e em acordo com o Empregador, remediar apropriadamente os defeitos.

O Contratante não é responsável por solucionar defeitos ou quaisquer danos às Instalações que surgirem como resultado de alguma das seguintes causas:

a) operação ou manutenção imprópria das Instalações pelo Empregador;

b) operação das Instalações fora das especificações fornecidas no Contrato;

c) uso normal;

d) (relacionado ao país onde a Obra está localizada) reação nuclear, radiação nuclear, contaminação radioativa, onda de pressão causada por queda de avião ou por outros objetos aéreos, ou quaisquer outras que um contratante experiente não poderia prever razoavelmente, ou se razoavelmente previsível não poderia fazer a provisão ou assegurá-la diante deste, tanto que tais riscos 
não são normalmente assegurados e são mencionados nas exclusões gerais da política do seguro, incluindo os Riscos de Guerra e os Riscos Políticos.

As obrigações do Contratante, acima descritas, não se aplicam para:

a) material que for adquirido e fornecido pelo Empregador, consumido normalmente na operação, ou tem uma vida normal mais curta que o Período de Responsabilidade por Defeito estabelecido;

b) todo o uso ou ocupação, de qualquer parte das Instalações, pelo Empregador ou por qualquer terceiro (a exceção de um Subcontratado) autorizado pelo Empregador;

c) todo o uso ou confiança diante de qualquer projeto, dados ou especificação fornecidos ou designados pelo Empregador ou em seu nome, ou para quaisquer questões que o Contratante tenha negado sua responsabilidade, o Empregador paga ao Contratante toda soma pagável no respeito das Instalações executadas;

d) quaisquer outros materiais fornecidos ou trabalho executado pelo Empregador ou em seu nome, à exceção do trabalho executado pelo Empregador para solucionar o defeito ou quaisquer danos às Instalações, de responsabilidade do Contratante.

O Contratante garante que, durante o Teste de Garantia, as Instalações e todas as suas partes, alcançarão as Garantias Funcionais especificadas no Acordo de Contrato.

Se, por razões atribuídas ao Contratante, o nível mínimo das Garantias Funcionais, especificadas no Acordo de Contrato, não for atendida tanto por inteiro ou na parte, o Contratante deve, a seu custo e despesa, realizar mudanças, modificações e/ou adições ao equipamento e sistemas, ou em qualquer parte destes, de modo a atingir ao menos o nível mínimo de tais Garantias. Se o Contratante eventualmente não conseguir atender o nível mínimo de Garantias Funcionais, o Empregador pode considerar o término do Contrato.

\subsubsection{Distribuição do risco}

No proposto a condições imprevistas, durante a execução do Contrato, o Contratante encontrar no local da Obra, quaisquer condições físicas (outras que não climática) ou obstruções artificiais, que não puderam ser razoavelmente previstas, a priori da data do Acordo de Contrato, por um experiente Contratante, nas bases de um razoável exame dos dados, relacionados às Instalações, fornecidos pelo Empregador e 
baseado nas informações que puder obter da inspeção visual do local da Obra (se disponível o acesso) ou outros dados prontamente disponíveis e relacionado às Instalações, o Contratante pode determinar que em conseqüência de tais circunstâncias ou obstruções incorrerá adicionais custos e despesas ou requererá tempo adicional para executar suas obrigações diante do Contrato.

Porém, o Contratante deve, prontamente e antes de realizar trabalhos adicionais ou usar equipamentos e sistemas adicionais, notificar o Gerente de Projeto por escrito com as seguintes informações:

a) condições físicas ou obstruções artificiais no local da Obra, que não puderam ser razoavelmente previstas;

b) o trabalho e/ou equipamentos e sistemas adicionais, requeridos, incluindo os passos os quais o Contratante irá ou propõem tomar para superar estas condições ou obstruções;

c) a extensão de atraso previsto;

d) adicionais custos e despesas, que é provável do Contratante contrair.

Recebendo qualquer notificação do Contratante, do acima referido, o Gerente de Projetos deve, prontamente, consultar-se com o Empregador e o Contratante e decidir sobre as ações a serem tomadas para superar as condições físicas e obstruções artificiais encontradas.

Neste contexto, "force majeure", significa todo o evento além do controle razoável do Empregador ou do Contratante, conforme as circunstâncias, e o qual é inevitável, apesar dos razoáveis cuidados pela parte afetada, incluindo o seguinte:

a) guerra, hostilidades ou operações bélicas (se um estado de guerra esteja declarado ou não), invasão, ato de inimigo estrangeira e guerra civil;

b) rebelião, revolução, insurreição, motim, usurpação do governo civil ou militar, conspiração, desordem, tumulto civil e ato terrorista;

c) confiscação, nacionalização, mobilização, comandado ou requisitado por ou sob ordem de qualquer governo, autoridade de fato ou ditador;

d) greve, sabotagem, embargo, limitação de importação, congestionamento portuário, falta de meios usuais de transporte público e comunicação, disputa industrial, naufrágio, escassez ou limitação de fornecimento de energia, epidemias, quarentena e pragas;

e) terremoto, desmoronamento, atividade vulcânica, fogo, inundação, onda gigante, tufão ou ciclone, furacão, tempestade, relâmpago, ou outras 
condição severas de tempo, ondas nucleares e de pressão ou outros desastres natural ou físico;

f) escassez de trabalho, materiais ou utilidades, na qual a causa for por circunstâncias de "Force Majeure".

A parte ou as partes afetadas, pelo evento da "Force Majeure", usam esforços razoáveis para aliviar o efeito deste evento, e cumprir suas obrigações sob o Contrato, mas sem prejudicar o direita das outras partes de terminar o Contrato.

Se o desempenho do Contrato estiver substancialmente impedido, retardado ou atrasado para um período único de mais de sessenta (60) dias ou um período agregado de mais de cento e vinte (120) dias, em decorrência de um ou mais eventos de "Force Majeure", durante a ocorrência do Contrato, as partes tentam desenvolver uma solução mutuamente satisfatória, vindo a falhar, uma ou outra parte pode terminar o Contrato, notificando aos outros, desde que não prejudique o direito das outras partes de terminar o Contrato.

\subsubsection{Mudança em elementos do Contrato}

O Empregador tem o direito de propor, e subseqüentemente requerer que o Gerente de Projeto encomende do Contratante, de tempo em tempo, durante o desempenho do Contrato, a realização de qualquer mudança, modificação, adição ou remoção, nas ou para as Instalações, contanto que tal mudança encaixe dentro do escopo geral das Instalações e não constitua trabalho sem relação, e seja tecnicamente praticável, levando em conta o estado do avanço das Instalações e da compatibilidade técnica da Mudança prevendo a natureza das Instalações, como especificadas no Contrato.

O Contratante pode, de tempo em tempo, durante seu desempenho no Contrato, propor ao Empregador (com uma cópia ao Gerente de Projeto) quaisquer mudanças que o Contratante considerar necessário ou desejável para melhorar a qualidade, a eficiência ou a segurança das Instalações. O Empregador pode, em sua discrição, aprovar ou rejeitar quaisquer Mudanças propostas pelo Contratante, contanto que o Empregador aprove qualquer mudança proposta pelo Contratante de forma a assegurar a segurança das Instalações.

Término por conveniência do Empregador. O Empregador pode a qualquer momento terminar o Contrato por qualquer razão, dando ao Contratante uma notificação de término referente a este. 
Assim que receber a notificação de término, o Contratante deve, de acordo com a data especificada na notificação de término:

a) cessar todos trabalhos, à exceção de trabalhos que o Empregador especificar na notificação de término para a finalidade única de proteger parte das Instalações já executadas, ou qualquer trabalho requerido para sair do local da Obra em condição limpa e segura;

b) terminar todos os subcontratos, a não ser aqueles atribuídos ao Empregador, conforme o parágrafo (d)(ii) abaixo;

c) remover todos os equipamentos do Contratante do local da Obra, repatriar o pessoal do Contratante e de seus Subcontratantes, remover do local da Obra todos os destroços, refugos e restos de qualquer tipo, e deixar todo o local em condições limpas e segura;

d) Ademais, o Contratante, a despeito do pagamento especificado no parágrafo abaixo, deve:

i. entregar, ao Empregador, as partes das Instalações executadas, pelo Contratante, até a data do término;

ii. à extensão legalmente possível, atribuir ao Empregador todos os direitos, títulos e benefícios do Contratante para com as Instalações, equipamento e sistemas até a data do término, podendo ser requerido pelo Empregador, em todos os subcontratos concluídos entre o Contratante e seu Subcontratantes;

iii. entregar ao Empregador todos os desenhos sem proprietário, especificações e outros documentos preparados pelo Contratante ou por seus Subcontratantes até a data do término, em relação às Instalações.

No caso do término do Contrato, o Empregador paga ao Contratante os seguintes montantes:

a) o Valor do Contrato, corretamente atribuído às partes das Instalações executadas pelo Contratante até a data do término;

b) os custos, razoavelmente, incorridos pelo Contratante na remoção do equipamento do Contratante do local da Obra e no repatriamento do seu pessoal e do pessoal dos seus Subcontratantes; 
c) todas as quantias a serem pagas pelo Contratante a seus Subcontratantes, em relação ao término de quaisquer subcontratos, incluindo todos os custos de encargos;

d) custos contraídos pelo Contratante em proteger as Instalações e deixar o local da Obra em uma condição limpa e segura;

e) o custo de satisfazer a todas as obrigações, compromissos e reivindicações restantes, que o Contratante pode, na boa fé, ter empreendido com terceiras partes em conexão com o Contrato e não está coberto pelos itens de (a) a (d), acima exposto.

No caso de término por negligência do Contratante, o Empregador, sem prejuízo a quaisquer outros direitos ou correções que possua, pode terminar o Contrato imediatamente, nas seguintes circunstâncias, dando uma notificação de término e de suas razões ao Contratante:

a) se o Contratante se tornar falido ou culminar em falta de capacidade;

b) se o Contratante atribuir ou transferir o Contrato ou algum direito ou interesse nele, na violação de condições pré-estabelecidas;

c) se o Contratante, no julgamento do Empregador, utilizar práticas corruptas ${ }^{27}$ ou fraudulentas ${ }^{28}$ em competições ou execuções do Contrato.

Se o Contratante:

a) abandonar ou repudiar o Contrato;

b) ter, sem razão válida, fracassado em começar, prontamente, o trabalho nas Instalações ou suspendeu o progresso do desempenho do Contrato por mais de vinte e oito (28) dias após ter recebido uma instrução escrita do Empregador para proceder;

c) de forma persistente, não executa o Contrato em conformidade ou negligencia persistentemente realizar suas obrigações sob o Contrato, sem justa causa;

d) recusa ou é incapaz de fornecer materiais, serviços ou trabalho suficiente para executar e terminar as Instalações da maneira especificada no Programa

\footnotetext{
27 "Prática corrupta" significa oferecer, dar, receber ou solicitar qualquer coisa de valor influenciando a ação de um oficial público no processo da obtenção ou da execução do Contrato.

28 "Prática fraudulenta" significa a adulteração dos fatos a fim de influenciar um processo de obtenção ou de execução de um Contrato em detrimento do Empregador, e inclui a prática de conspiração entre os licitantes (antes ou depois da submissão da oferta) projetadas para estabelecer preços de oferta em níveis artificiais e não competitivos privando o Empregador dos benefícios da competição".
} 
de Performance fornecido, nas taxas de progresso que dão a garantia razoável ao Empregador que o Contratante pode alcançar a conclusão das Instalações em acordo com o determinado Período para Conclusão e prolongamentos.

Então o Empregador pode, sem prejuízo a quaisquer outros direitos que puder possuir sob o Contrato, notificar o Contratante, indicando a natureza do defeito, requerendo do Contratante solucionar o mesmo. Se o Contratante falhar em solucionar ou em propor as etapas para remediar o mesmo, dentro de quatorze (14) dias a partir da notificação, o Empregador pode terminar o Contrato, dando, imediatamente, uma notificação de término ao Contratante referente ao acima exposto.

Término pelo Contratante, se:

a) o Empregador falhou em pagar ao Contratante qualquer soma devida sob o Contrato, dentro do período especificado, falhou em aprovar qualquer fatura ou documentos de sustento sem justa causa, conforme o Acordo de Contrato, ou cometeu uma violação substancial do Contrato. Assim o Contratante pode notificar o Empregador que requer o pagamento de tal soma, requerendo a aprovação de tais faturas ou documentos de sustento, ou especifica a violação e requer do Empregador remediar o mesmo, conforme as circunstâncias. Se o Empregador não pagar tal soma, não aprovar tais faturas ou documentos de sustento, nem der suas razões para reter tal aprovação, não remediar as violações, nem determinar as etapas para remediar as violações dentro de quatorze (14) dias após receber a notificação do Contratante, ou

b) o Contratante é incapaz de realizar alguma de suas obrigações sob o Contrato por alguma razão atribuída ao Empregador, incluindo, mas não limitado, à falha do Empregador fornecer a possessão ou acesso ao local da Obra ou as outras áreas, ou falhar em obter qualquer licença governamental necessária para a execução e/ou a conclusão das Instalações,

Então o Contratante deve notificar imediatamente o Empregador do término do Contrato. O Contratante pode terminar o Contrato, dando, imediatamente, uma notificação, se o Empregador se tornar falido ou faltar capacidade.

\subsection{Considerações finais}

Os três Lotes foram formados por Joint Ventures/Consórcios de quatro (4) empresas cada, porém os lotes 2 e 3 possuem a mesma configuração, ou seja, o mesmo 
conjunto de empresas ganhou o Contrato. Mesmo possuindo a mesma configuração os Contratantes dos Lotes 2 e 3 devem ser abordados como entidades distintas.

Mesmo que a análise de campo não pôde ser feita por completo, uma vez que, não foi possível percorrer a totalidade de obras e canteiros de obra já implantados ou que virão a ser implantados, pode-se observar que ao dar início à Operacionalização do empreendimento, por ordem de conformidade e conveniência de forma a atender um equilíbrio dinâmico ${ }^{29}$ as oito (8) empresas (quatro referentes ao Lote 1 e as quatro referentes ao Lote 2 e 3) formaram um arranjo (“consórcio/grupo"), no qual uma destas empresas se caracteriza como líder, cuidando da gestão. Por este arranjo cada uma das oito empresas designa um representante(s) a fim de formar uma comissão de representantes que cuidarão de questões pertinentes e decisões a serem tomadas para o bom desenvolvimento do empreendimento e articulação do consórcio. Um ponto observado e levantado por pessoas articuladas ao empreendimento é que o arranjo de oito (8) empresas acabou sendo encorajado pelo espaço, destinado à implantação dos canteiros de obra e das instalações, ser um ponto crítico característico de obra em área urbana, como é a cidade de São Paulo, principalmente em suas regiões centrais, carente de espaços físicos e de tráfego complexo. Cabendo destacar que tais observações foram estruturadas segundo pontos de vista e análises valiosas sendo próprio de um ou de vários sujeitos, porém não é válido afirmar que seja para todos.

Utilizando a revisão bibliográfica juntamente com os dados coletados pelo Estudo de Caso, torna-se viável propor um modelo baseado nos Processos de Negócios que relacione os conceitos de PCP, Rede de Cooperação e Ciclo de vida utilizando a metodologia de modelagem EKD, de forma que sistematize os conceitos de planejamento e controle da produção no ambiente de redes de cooperação assimétricas.

$\mathrm{O}$ fato de o modelo proposto utilizar como objeto de analise uma obra de construção se mostra coerente, já que uma obra de construção civil detém as características necessárias: grupo de empresas autônomas, unidas com o objetivo de agregar competência de forma a atender uma oportunidade específica apresentando uma relação contratual formal, com presença marcante de uma hierarquia de poder.

Os Elementos do Contrato de Consórcio (Sujeitos; Requisitos de atividade econômica exercida por cada um dos sujeitos; Susceptível de graus; Obrigação de boa fé; Caráter evolutivo e; Ponto de vista produtivo), abordados no tópico 2.4 do presente

\footnotetext{
${ }^{29}$ Conceito abordado no tópico 2.4 , referente a contrato de consórcio.
} 
trabalho, podem, claramente, ser identificados nesta coleta de dados, cabendo ressaltar, no condizente ao elemento Caráter evolutivo, o DRB (comissão examinadora de disputas), prevendo uma forma amigável de solucionar eventuais problemas. Quanto ao elemento Ponto de vista produtivo, o consórcio do Metrô, abordado na coleta de dados, detêm um comportamento tanto horizontal quanto vertical, uma vez que, três das quatro empresas participantes estão no mesmo ramo.

Ao analisar o Programa de Execução do Lote 1 (Anexo A) observa-se a realização do planejamento e programação sendo realizada de trás para frente, ou seja, partindo-se da data máxima, juntamente com as capacidades e restrições determina-se as etapas, sendo dezoito (18) as principais etapas (Implantação da Obra Civil, Poço/Ventilação João Teodoro, Estação Luz, Ventilação Rio Branco, Poço 24 de Maio, Túneis 24 de Maio - República NATM, Estação República, Túneis Hilton - República NATM, Poço Hilton, Ventilação Roosevelt, Estação Higienópolis, Ventilação Cel. José Eusébio, Túnel Estacionamento, Estação Paulista, Ventilação Incor, Estação Oscar Freire, Ventilação Brasil e Via Permanente), as quais ocorrem em paralelo.

O Relatório de progresso (item 6.2.10) utiliza o conceito de PPC (Percentage of Planned Completed Activities), indicador de desempenho operacional, de modo que a sua utilização favorece a visualização da necessidade de replanejamento e reprogramação. Segundo Ballard e Howell (1994) apud Conte (1997), o PPC fornece importantes informações sobre perdas potenciais de desempenho, geradas por falhas na alocação de recursos durante a execução dos trabalhos. 


\section{ANÁLISE DOS DADOS E RESULTADOS}

\subsection{Introdução}

O presente capítulo objetiva apresentar através da consolidação da revisão bibliográfica e do estudo de caso, a Modelagem do Planejamento e Controle da Produção em um consórcio de empresas. Para a apresentação deste modelo utilizou-se a metodologia EKD. Inicialmente, o capítulo promove a análise dos dados coletados, para em seguida apresentar a modelagem propriamente dita, juntamente com uma breve descrição de seu conteúdo. Ao final, descreve-se uma etapa da obra abordada na coleta de dados, utilizando a metodologia EKD.

\subsection{Análise e integração dos dados coletados e conceitos abordados}

Expandindo a Figura 10 - composta pelos conceitos: ciclo de vida, elementos morfológicos e processo de negócio Produzir, segundo a metodologia EKD - será proposto um Modelo base para referência (Figura 12), o qual será o ponto de partida e direcionador da análise de dados. Os submodelos, componentes básicos da composição do modelo base para referência, requerem atenção e análise individualizada, sendo eles os seguintes: processo, ator e recurso, objeto, regra e objetivo.

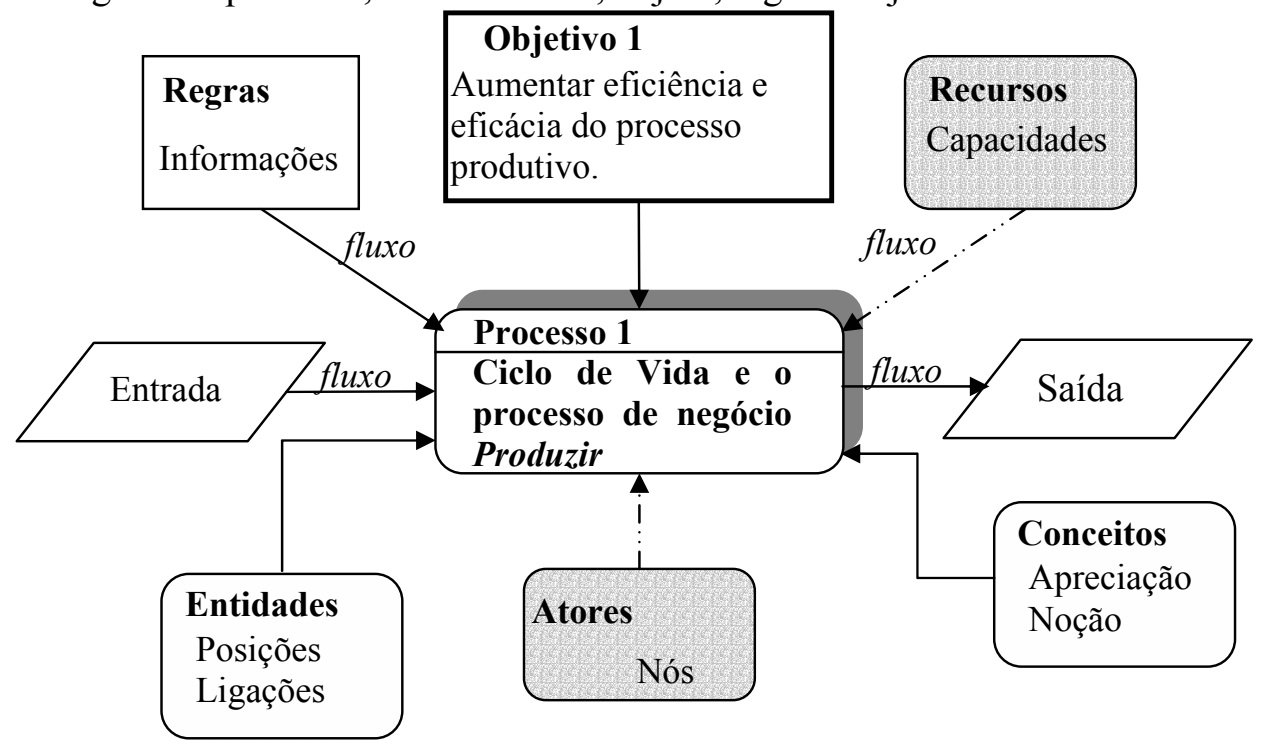

Figura 12: Componentes básicos para compor um modelo de referência, proposto segundo o EKD. 


\subsubsection{Submodelo de processo}

Este submodelo tem como objetivo definir processos organizacionais, mostrando a forma de interação e manuseio das informações e materiais, consumindo as entradas em termos de informações e/ou materiais e produzir saídas de informação e/ou materiais. A representação gráfica é a seguinte (Figura 13):

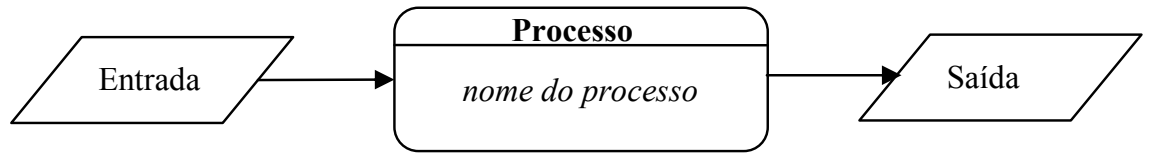

Figura 13: Representação do submodelo processo

A boa compreensão da dinâmica da rede está ligada à análise do ciclo de vida dela, junto a isso se tem o processo de negócio Produzir percorrendo todo o ciclo de vida da rede. Foi esta razão que proporcionou a divisão do submodelo de processo de acordo com as fases do ciclo de vida da rede proposto por Camarinha-Matos e Afsarmanesh (1999 a,b), que são: criação/configuração, operação, evolução/reconfiguração e, dissolução; uma proposta que condiz com as necessidades do setor da construção civil.

Desse modo tem-se a seguinte configuração:

- Processo 1.1 - Criando/Configurando;

- Processo 1.2 - Operacionalizando;

- Processo 1.3 - Evoluindo/Reconfigurando;

- Processo 1.4 - Dissolvendo.

Quanto às entradas e saídas destes Processos tem-se:

- entrada do Processo 1.1: A oportunidade de negócio gerada pela Implementação da Linha 4 do Sistema de Mêtro de São Paulo.

- saída do Processo 1.1 e entrada do Processo 1.2: Estabelecimento de objetivos, identificação de parceiros, relacionamentos entre partes, elaboração de business case, plano de recurso, administração de capacidade e, regulamentação do local da obra;

- saída do Processo 1.2 e entrada do Processo 1.3: Moldando processos de negócio, operacionalizada/colocada em funcionamento, programação da produção distribuídas e dinâmicas, programação distribuída de tarefas, relatório de progresso, plano de garantia de qualidade, testes e/ou inspeções, pré-delegação, delegação, garantias funcionais, propostas de mudanças e, alcançar seus objetivos; 
- saída do Processo 1.3 e entrada do Processo 1.4: Remoldando processos de negócio, Reoperacionalizado, Reaproveitamento de ativos, programação da produção distribuídas e dinâmicas, programação distribuída de tarefas, relatório de progresso, plano de garantia de qualidade, testes e/ou inspeções, pré-delegação, delegação, garantias funcionais, propostas de mudanças e, objetivos alcançados;

- saída do Processo 1.4: Finalizados os processos de negócio, dispersão, conclusão do empreendimento e, término do contrato.

\subsubsection{Submodelo de ator e recurso}

Este submodelo define quais os tipos de atores e recursos envolvidos nas atividades organizacionais. Sendo sua representação gráfica a seguinte (Figura 14):

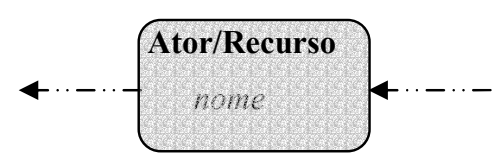

Figura 14: Representação do submodelo ator e recursos

O submodelo de ator está relacionado aos elementos morfológicos Nós, definidos como as empresas ou indivíduos constitutivos da rede de empresas. De modo que, por meio dos dados coletados, se discriminam como atores/nós, os seguintes componentes do consórcio: Consórcio; Metrô; IDA; IBRD; Gerente de projeto; Empresas participantes do consórcio; Representante do consórcio; Concessionária da Linha 4 do Mêtro, Representante da Concessionária; Empresas subcontratadas e; Empresas subcontratadas especialistas.

O submodelo de recursos está vinculado às capacidades e recursos definidos como fundamentais para realizar o empreendimento Linha 4 do Metrô. De acordo com o exigido para a qualificação das empresas, podem-se considerar como elementos para compor o submodelo de recursos, atender aos critérios de: experiência geral, experiência particular, capacidade financeira, capacidade pessoal e capacidade de equipamentos; além desses pode-se considerar a Comissão Examinadora de Disputas (DRB) como um recurso, desenvolvido para o bom funcionamento do consórcio.

\subsubsection{Submodelo de entidade e conceitos ou submodelo de objeto}

O submodelo de objeto é utilizado para definir entidades e dados da aplicação em níveis conceituais, servindo como dicionário. Entidade constitui alguma coisa de 
interesse e aplicação que deve ser entendida e caracterizada. A caracterização gráfica do submodelo de objeto é a seguinte (Figura 15):

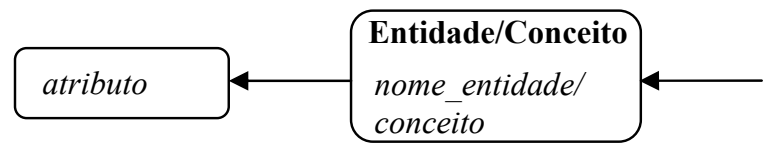

Figura 15: Representação do submodelo entidade/conceito e atributo

O submodelo de objeto está articulado aos elementos morfológicos Posições (divisão do trabalho que conecta os diferentes agentes visando atingir determinado objetivo) e Ligações (relacionamento entre as empresas).

Pode-se determinar como sendo uma das possíveis configurações de Entidade;Posição os seguintes elementos:

1. trabalhos civis
a. demolição de edificações
b. remoção de interfaces
c. túneis
d. estruturas
e. estações
f. vias permanentes
g. serviços de finalização
h. paisagismo
i. urbanização
j. serviços complementares

2. sistemas
a. provisão de energia
b. sistemas auxiliares
c. sistemas de telecomunicações, voz e vídeo
d. sistemas de controle local
e. iluminação
f. escadas rolantes
g. elevadores

3. projetos detalhados dos trabalhos civis

4. projetos detalhados dos sistemas

5. implementação da estrada de ferro 
Outra possível configuração é analisar segundo as etapas de obra prédeterminadas no Programa de Execução. Conforme o Anexo A, referente ao Lote 1, elas seriam dezoito (18) Entidades;Posições: implantação da obra civil, poço/ventilação João Teodoro, estação Luz, ventilação Rio Branco, poço 24 de maio, túneis 24 de maio - República NATM, estação República, túneis Hilton - República NATM, poço Hilton, ventilação Roosevelt, estação Higienópolis, ventilação Cel. José Eusébio, túnel Estacionamento, estação Paulista, ventilação Incor, estação Oscar Freire, ventilação Brasil e via permanente.

Quanto aos elementos analisados, como virtuosas Entidades;Ligações têm-se: empregador, joint venture/consórcio, contratante, concessionária, subcontratante e, subcontratante especialista.

Existem elementos que devem ser abordados pelo submodelo de objetos, porém não se caracterizam como Posição nem Ligação, são eles: conceitos, atributos e entidades simples. É interessante incluir no submodelo de objetos os conceitos "Force Majeure" e Banco Mundial, pelo potencial de influenciar e inferir no empreendimento como um todo. Pode-se destacar como atributo (propriedade de um tipo de objeto) do Banco Mundial o montante do empréstimo (EUA \$209,000,000). Licitação deve ser caracterizada como uma entidade, simples, porém de interesse, visto que ela constitui a essência do processo de Criação/Configuração e possui individualidade (a licitação de implementação da Linha 4 do Metrô de São Paulo).

\subsubsection{Submodelo de regra}

O submodelo de regra tem como finalidade definir e manter as regras do negócio formuladas, consistentes e claras, balizando os demais submodelos. Sua representação gráfica é conforme a Figura 16:

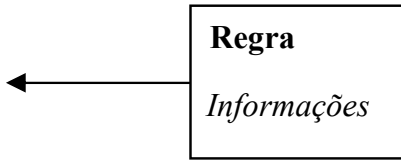

Figura 16: Representação do submodelo regra

Desse modo, por meio dos dados coletados, as regras declaradas e de conhecimento geral pertinentes à boa compreensão e condita do empreendimento, estão descritas a seguir: 
1. A licitação é administrada conforme as regras e procedimentos estabelecidos nas Diretrizes de obtenção de empréstimos e créditos do IBRD/IDA em conformidade com a Lei Federal n ${ }^{\circ} 8666 / 93$ e Lei Estadual $n^{\circ}$ 6544/89;

2. O Representante do Contratante dará ao Gerente de Projetos todas as observações, instruções e demais comunicações acerca do Contrato referente ao Contratante. Do início da implantação até a conclusão, supervisionará todo o trabalho feito na Obra pelo Contratante, devendo estar presente no local durante as horas normais de funcionamento, exceto diante de imprevistos e licenças;

3. O Gerente de Projetos dará todas as observações, instruções, ordens, certificados, aprovações e demais comunicações acerca do Contrato, exceto quando determinado de outro modo;

4. Nenhum pagamento feito pelo Empregador será julgado a constituir a sua aceitação das Instalações ou qualquer parte(s) dela;

5. Joint Venture/Consórcio que inclua sócio de países inelegíveis ou empresas inelegíveis não será permitido participar;

6. A qualificação, capacidade e recursos de Subcontratantes propostos não será levada em consideração na avaliação de candidatos individuais ou de Joint Venture/Consórcios a menos que nomeados subcontratados especialistas;

7. Pode ser subcontratado $20 \%$ dos trabalhos civis e de todo o equipamento a ser provido;

8. Ao subcontratar quaisquer elementos altamente especializados dos trabalhos para Subcontratantes especialistas, estes elementos devem ser identificados e os Subcontratantes propostos claramente, descrevendo suas experiências e capacidades pertinentes;

9. Comprovar atender aos critérios exigidos de Experiência Geral (Tabelas 07, 08, 09 e 10);

10. Comprovar atender aos critérios exigidos de Experiência Particular (Tabelas 11,12 e 13);

11. Comprovar atender aos critérios exigidos de Capacidade Financeira (Tabela $14)$;

12. Comprovar atender aos critérios exigidos de Capacidade Pessoal (Tabela $15)$; 
13. Comprovar atender aos critérios exigidos de Capacidade de Equipamento (Tabela 16);

14. O Contratante deve, com o devido cuidado e zelo, projetar, executar, terminar os trabalhos e remediar os defeitos de acordo com as provisões do Contrato. Fornecendo toda a superintendência, trabalhos, materiais, plantas, equipamentos e todo o restante de natureza provisória ou permanente, requerido para tais;

15. Joint Venture/Consórcio, o parceiro no comando será o Contratante de trabalhos civis que tenha um montante anual maior que $40 \%$ do exigido na experiência geral (Tabela 09), os demais parceiros deverão ter um montante anual maior que 20\%. Para instalações de equipamentos e sistemas os parceiros deverão ter um montante anual maior que $15 \%$ do exigido na experiência geral (Tabela 10);

16. Joint Venture/Consórcio o parceiro no comando proverá ao menos $40 \%$ da Experiência Particular requeridas (Tabela 11);

17. O Contratante deve fabricar ou obter e transportar todo o Equipamento e Sistemas de maneira ordenada e planejada ao canteiro de obra, a seus próprios riscos e despesas pela modalidade que julgar apropriada;

18. O parceiro no comando será autorizado a adquirir responsabilidades e receber instruções para e em nome de qualquer dos parceiros da Joint Venture/Consórcio ;

19. Em todo teste e/ou inspeção o Gerente de Projeto promoverá a cooperação e a coordenação entre o Contratante e o Empregador diretamente ou através da Concessionária para que, futuramente se obtenha uma agradável operação das Instalações;

20. O Empregador deve adquirir e providenciar a posse legal e física do local da obra e acessos a ela e, providenciar a posse e acessos a todas as áreas requeridas à apropriada execução do empreendimento;

21. O Empregador usará seus melhores esforços, dando assistência ao Contratante, na obtenção de maneira oportuna e rápida de todas as permissões, aprovações e/ou licenças necessárias à execução do Contrato, assistindo também de forma a beneficiá-lo de uma economia do montante de impostos; 
22. O Contratante deve executar seu trabalho de forma a minimizar interferências com o trabalho de outros Contratantes;

23. O Contratante não alcançando a conclusão das Instalações ou, qualquer parte delas, dentro do período determinado, pagará ao Empregador a liquidação dos danos, não o isentando de suas responsabilidades sobre o não cumprimento de metas estabelecidas, perdas e danos relacionados, sofridos pelo Empregador;

24. O período de responsabilidade por defeitos será de 18 meses da data da Conclusão das Instalações ou qualquer parte delas ou, 12 meses da data da Aceitação Operacional das Instalações ou qualquer parte dela;

25. O Contratante pode terminar o Contrato quando o Empregador falhar em the pagar qualquer soma devida sob o Contrato, dentro de período especificado, falhar em aprovar qualquer fatura ou documento de sustento sem justa causa ou quando o Contratante for incapaz de realizar alguma de suas obrigações sob o Contrato por alguma razão atribuída ao Empregador;

26. O Empregador pode a qualquer momento terminar o Contrato por qualquer razão, dando ao Contratante uma notificação de término;

27. O Contratante pode, durante seu desempenho no Contrato, propor ao Empregador quaisquer mudanças que considerar necessárias ou desejáveis para melhorar a qualidade, a eficiência, a segurança das Instalações;

28. O Empregador tem o direito de propor e requerer que o Gerente de Projeto encomende do Contratante, durante a execução do Contrato, a realização de quaisquer mudanças, modificação, adição ou remoção, nas ou para as Instalações, contanto que tal mudança encaixe dentro do escopo geral das Instalações e não constitua trabalho sem relação, sendo tecnicamente praticável;

29. O Empregador deve aprovar qualquer mudança proposta, pelo Contratante, de forma a assegurar a segurança das Instalações.

\subsubsection{Relacionamentos entre submodelos}

No desenvolvimento de um modelo organizacional, as ligações entre os componentes de diferentes submodelos executam uma tarefa fundamental para disponibilizar o conhecimento. O elemento morfológico fluxo pode ser interpretado 
como as ligações e/ou relacionamentos entre submodelos. O elemento morfológico fluxo pode ser observado, principalmente, nas seguintes interações de submodelos:

- processos - atores e recursos: Tipicamente descreve como os atores e recursos são relacionados ou envolvidos nos processos;

- processos - objetos: Estão entre o conjunto de informações do processo e os componentes necessários. Como exemplo o consórcio, o conjunto de informação "identificação de parceiros e relacionamentos entre partes" deve referir-se as entidades, incluindo atributos e relacionamentos que indiquem quem são estes parceiros e como se relacionam;

- regras - processos: Normalmente descreve como os processos são disparados pelas regras do negócio;

- regras - atores e recursos: Normalmente descreve como os diferentes atores e recursos são balizados pelas regras do negócio.

As ligações podem ser estabelecidas de muitas formas, dependendo do escopo e propósito do modelo EKD em particular.

\subsection{Apresentação da Modelagem do Planejamento e Controle da Produção}

O objetivo é sistematizar o PCP no ambiente de redes de empresas assimétricas, incorporando os conceitos de ciclo de vida da rede, elementos morfológicos e processo de negócio, a partir do Modelo base para referência (Figura 12) em conjunto com os dados coletados e do referencial teórico, utilizando a metodologia EKD, conforme a Figura 17.

Uma vez que os modelos apresentam percepções subjetivas do objeto de análise, essa modelagem foi constituída utilizando como principal ponto de vista do empreendimento a percepção e noções do Metrô, principalmente por ele atender ao requisito de ter uma visualização ampla do objeto de análise e maior imparcialidade que os demais envolvidos no processo. 


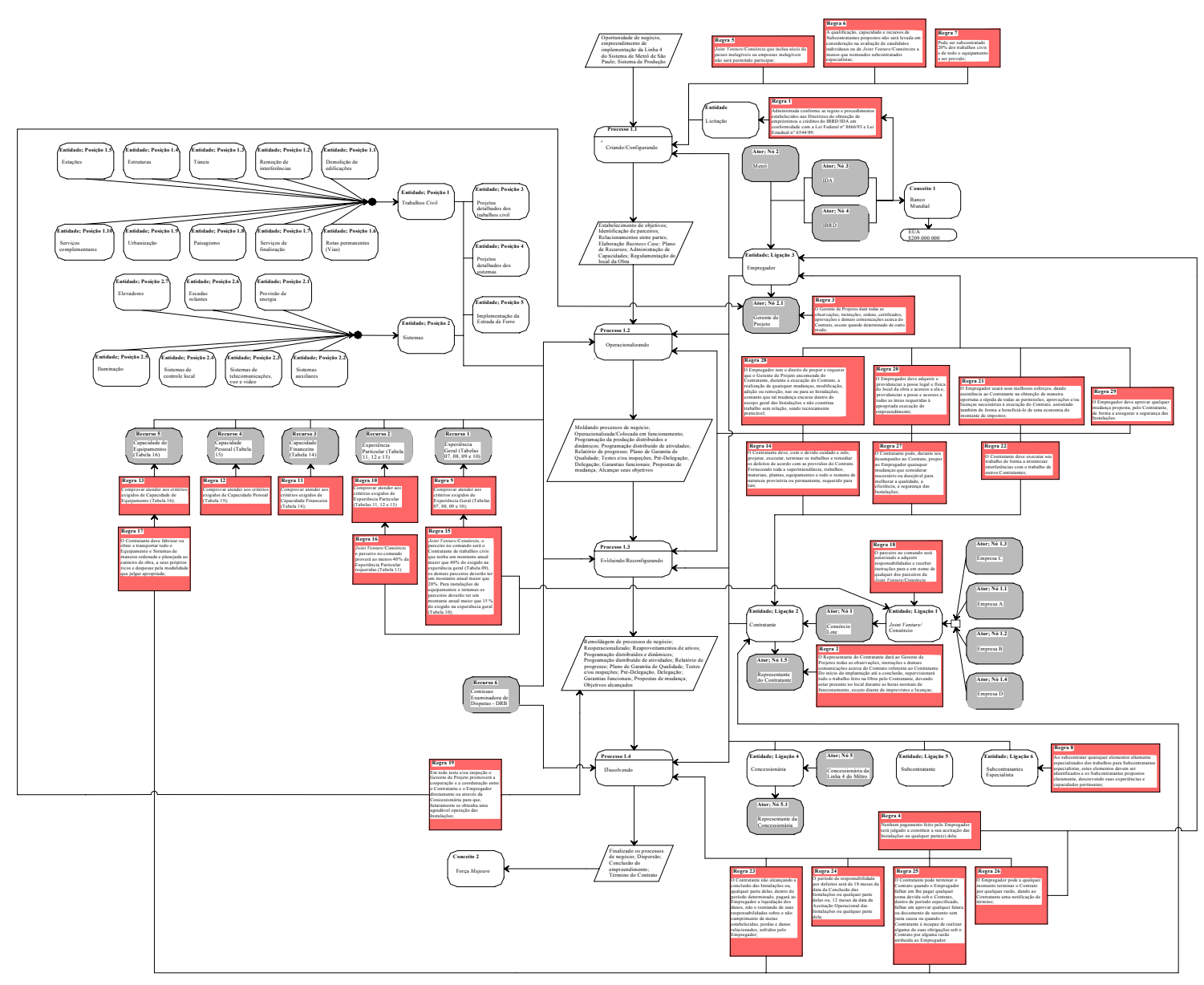

Figura 17: Modelagem do Planejamento e Controle da Produção em Consórcio 
$\mathrm{Na}$ Figura 17, a Entidade;Ligação1 - Joint Venture/Consórcio, composta por quatro (4) empresas (Empresas $A, B, C$ e $D$ ) morfologicamente analisadas como nós (nó 1.1 , nó 1.2 , nó 1.3 e nó 1.4 respectivamente) formaram o Consórcio do Lote (o Lote 1 deteve maior apreciação e facilidade de obtenção e coleta de dados, portanto principal objeto de análise) considerado o Ator; Nó 1. Diante do empreendimento e do contrato o Consórcio é conceituado como Contratante, portanto o Ator,Nó 1 - Consórcio do Lote 1 - passa a ser caracterizado como a Entidade; Ligação 2 - Contratante, responsável por designar um representante que atua ativamente no empreendimento dando todas as observações, instruções e demais comunicações acerca do Contrato, possuindo valor de nó (Ator,Nó 1.5 - Representante do Contratante).

Outra entidade de interesse ao empreendimento é o Empregador (Entidade; Ligação 2), constituída a partir de três (3) nós (Ator,Nó 2 - Metrô; Ator,Nó 3 - IDA; Ator,Nó 4 - IBRD) e responsável por designar um gerente de projeto (Ator,Nó 2.1) que dará todas as observações, instruções, ordens, certificados, aprovações.

As entidades Subcontratante (Entidade; Ligação 5) e Subcontratante Especialista (Entidade; Ligação 6) não tiveram seus nós identificados, por não apresentarem grande pertinência com o escopo da Modelagem, normalmente estas entidades apresentam relação de subordinação ao Contratante (baixa influência na gestão da produção) e, o grande número de relações de subcontratação saturaria a Figura 17. A Concessionária é uma entidade (Entidade; Ligação 4) constituída pelo Ator;Nó 5 - Concessionária Linha 4 do Metrô, devendo designar seu representante (Ator,Nó 5.1).

O Contratante, Subcontratante, Subcontratante Especialista e Concessionária atuam em três Processos (Operacionalizando, Evoluindo/Reconfigurando e Dissolvendo) diferente do Empregador que atua em todos os processos (fases do ciclo de vida), com destaque para o Processo 1.1 - Criação/Configuração responsável pela elaboração, caracterização, determinação e licitação do objeto a ser produzido, determinando recursos e capacidades (Tabelas 07, 08, 09, 10, 11, 12, 13, 14, 15 e 16) a serem acatadas para o bom desenvolvimento do empreendimento.

As capacidades e recursos necessários ao bom desenvolvimento do empreendimento estão discriminados, em conformidade com o submodelo de recursos, como:

Recurso 1: Experiência geral (Tabelas 07, 08, 09 e 10);

Recurso 2: Experiência particular (Tabelas 11, 12 e 13);

Recurso 3: Capacidade financeira (Tabela 14); 
Recurso 4: Capacidade pessoal (Tabela 15);

Recurso 5: Capacidade de equipamentos (Tabela 16).

Esses Recursos, por serem elementos requeridos e necessários, principalmente, aos Contratantes, Subcontratantes e Subcontratantes Especialista, assim como eles, estão relacionados aos processos Operacionalizando, Evoluindo/Reconfigurando e Dissolvendo. Assegurando que a resolução dos eventuais impasses e problemas, tem-se o Recurso 6 - DBR, iniciando suas operações assim que o Consórcio é constituído e exercendo suas funções, até mesmo, após a Conclusão do empreendimento.

Quanto às posições, como anteriormente mencionado, elas são basicamente cinco (5), sendo que duas delas foram generalizadas, da seguinte forma:

1. Entidade;Posição 1 - Trabalhos civis;

1. Entidade;Posição 1.1 - Demolição de edificações;

2. Entidade;Posição 1.2 - Remoção de interferências;

3. Entidade;Posição 1.3 - Túneis;

4. Entidade;Posição 1.4 - Estruturas;

5. Entidade;Posição 1.5 - Estações;

6. Entidade;Posição 1.6 - Vias permanentes;

7. Entidade;Posição 1.7 - Serviços de finalização;

8. Entidade;Posição 1.8 - Paisagismo;

9. Entidade;Posição 1.9 - Urbanização;

10. Entidade;Posição 1.10 - Serviços complementares;

2. Entidade;Posição 2 - Sistemas;

1. Entidade;Posição 2.1 - Provisão de energia;

2. Entidade;Posição 2.2 - Sistemas auxiliares;

3. Entidade;Posição 2.3 - Sistemas de telecomunicações, voz e vídeo;

4. Entidade;Posição 2.4 - Sistemas de controle local;

5. Entidade;Posição 2.5 - Iluminação;

6. Entidade;Posição 2.6 - Escadas rolantes;

7. Entidade;Posição 2.7 - Elevadores;

3. Entidade;Posição 3 - Projetos detalhados dos trabalhos civis;

4. Entidade;Posição 4 - Projetos detalhados dos sistemas;

5. Entidade;Posição 5 - Implementação da estrada férrea. 
As Entidades; Posições estão vinculadas aos Processos Operacionalizando e Evoluindo/Reconfigurando, demonstrando sua íntima ligação com a parte operacional do processo produtivo. Um ponto importante a destacar é a existência de ligações e relacionamentos entre as Entidades;Posições e Entidades;Ligações ou Entidades;Posições e Atores;Nós. Estas ligações e relacionamentos não foram trabalhados nessa Modelagem por conveniência, já que requer um maior nível de detalhamento da modelagem e, a configuração utilizada para discriminar as posições (trabalhos civis, sistemas, projetos detalhados dos trabalhos civis, projetos detalhados dos sistemas e implementação da estrada férrea) dificulta a interação entre os submodelos. Por outro lado, a Figura 18 aborda uma configuração das Entidades;Posições (analisando segundo as etapas de obra) e um nível de detalhamento, que facilita a interação com outros submodelos.

Com a finalidade de exemplificar uma etapa relacionada ao Lote 1, confrontando pontos de vista, tem-se a Figura 18. A etapa é um Poço de ventilação e de saída de emergência. A Figura 18 representa um Modelo que foca na fase Operacionalizando do ciclo de vida rede e demonstra um relacionamento entre as Entidades; Posição e Entidades; Ligação. O "consórcio" é representado segundo a subjetividade e percepção do canteiro de obra, sendo ele composto por oito (8) empresas (empresas do Lote 1 juntamente com as empresas do Lote 2 e 3) além de agregar cinco (5) Empresas Subcontratadas (Sub A, B, C, D e E) e o Metrô. 


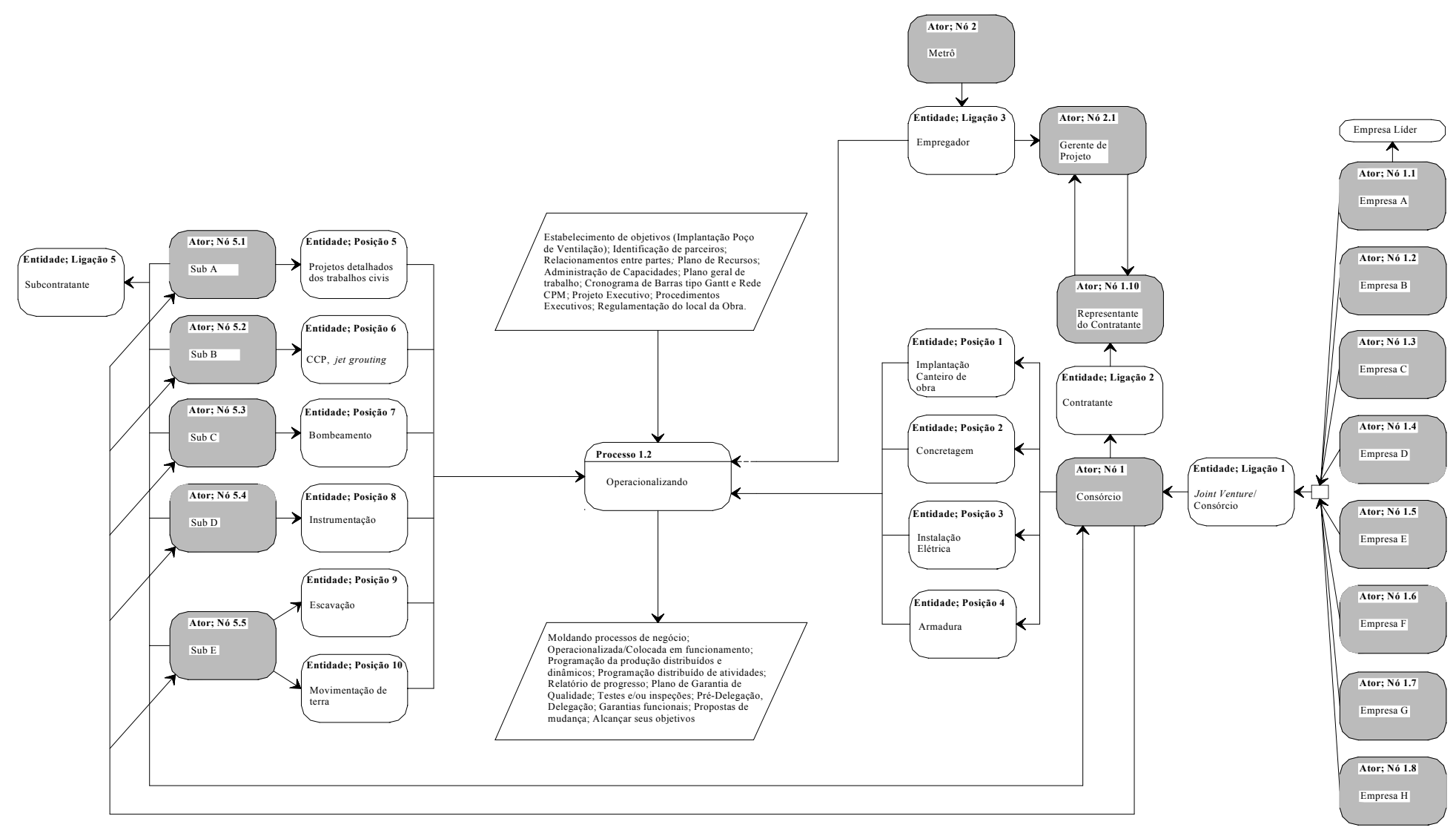

Figura 18: Modelo aplicado à fase Operacionalizando, referente a uma etapa do Lote1 
Como ressaltado, a fase do ciclo da rede Operacionalizando foi o único processo analisado, sua entrada é composta por:

- Estabelecimento de objetivos (que no caso em particular é a "Implantação do Poço de ventilação e saída de emergência");

- Identificação de parceiros, além do Consórcio como Contratante, do Metrô como Empregador, existem também empresas discriminadas como Subcontratantes;

- Relacionamento entre partes (os principais relacionamentos a serem moldados e desenvolvidos condizem com: Representante do Contratante em relação ao Gerente de projeto e, Consórcio em relação a empresas subcontratadas);

- Plano de recursos e administração de capacidades (aquisição de recursos observando prioridades e capacidades e, gestão de restrições);

- Plano geral de trabalho, cronograma de barras tipo Gantt e rede CPM, projeto executivo, procedimentos executivos (documentação descrita no Programa de Execução);

- Regulamentação do local da Obra, normalmente de responsabilidade do Empregador conforme Regra 20 da Modelagem (Figura 17).

A saída é composta por:

- Moldagem dos processos de negócio;

- Colocada em funcionamento (no sentido de que a implantação do poço começa a ser realizada, "a obra sai do papel”);

- Programação da produção distribuída e dinâmica, programação distribuída de atividades (determinação das pessoas, materiais, equipamentos e informações envolvidas e seus respectivos responsáveis na etapa, juntamente com as datas previstas para a execução dos trabalhos e as prioridades; então os alocando ao processo de trabalho, a cada momento, de forma correta e prioritária).

- Relatório de progresso, plano de garantia de qualidade, testes e/ou inspeções, pré-delegação, delegação e garantias funcionais (são os principais procedimentos de controle identificados e pertinentes); 
- Proposta de mudança (geralmente em caso de não conformidade com o planejado, necessidade em virtude da segurança ou impossibilidade de alcançar os objetivos);

- Alcançar seus objetivos (poço implantado em conformidade com as exigências).

Quanto às posições e seu relacionamento com os nós, a configuração é a seguinte:

- A Entidade;Posição 1 (implantação do canteiro de obra) relaciona-se com o Ator;Nó 1 (Consórcio);

- A Entidade;Posição 2 (concretagem) relaciona-se com o Ator;Nó 1 (Consórcio);

- A Entidade;Posição 3 (instalações elétricas) relaciona-se com o Ator;Nó 1 (Consórcio);

- A Entidade;Posição 4 (armadura) relaciona-se com o Ator;Nó 1 (Consórcio);

- A Entidade;Posição 5 (projetos detalhados dos trabalhos civis) relaciona-se com o Ator;Nó 5.1 (Subcontratada A);

- A Entidade;Posição 6 (CCP, jet grouting) relaciona-se com o Ator;Nó 5.2 (Subcontratada B);

- A Entidade;Posição 7 (sistemas de bombeamento) relaciona-se com o Ator;Nó 5.3 (Subcontratada C);

- A Entidade;Posição 8 (instrumentação) relaciona-se com o Ator;Nó 5.4 (Subcontratada D);

- A Entidade;Posição 9 (escavação) relaciona-se com o Ator;Nó 5.5 (Subcontratada E);

- A Entidade;Posição 10 - (movimentação de terra) relaciona-se com o Ator;Nó 5.5 (Subcontratada E);

Pode-se observar, em relação às ligações e relacionamentos do Processo Operacionalizando, que sua tendência é de aproximar das Entidades;Posições; Visto que, as posições estão associadas a uma determinada divisão do trabalho, conectando diferentes agentes, visando atingir determinado objetivo e integrando capacidades operacionais. 
O relacionamento do Consórcio com as Empresas subcontratadas, normalmente, é realizado de forma individualizada, ou seja, o Consórcio dificulta o estabelecimento de um consenso coletivo por parte das subcontratadas, facilitando a subordinação delas.

\subsection{Considerações finais}

O objetivo principal desta pesquisa está relacionado com a identificação de eventuais processos e atividades de interesse para o PCP em uma rede de empresas assimétrica.

Quanto ao processo de interesse, pode-se destacar o processo de negócio Produzir percorrendo o ciclo de vida da rede.

O objeto de análise, a obra de implementação da Linha 4 do Sistema de Metrô de São Paulo, sustenta o conceito de sistema produtivo por projeto ou sistema de engenharia e produção sob encomenda, caracterizado pelo produto final ser de posição fixa, único, com ciclo de vida longo, projeto específico e inconstância de recursos em habilidades e quantidades, destacando a importância da análise dos critérios de capacidades e restrições.

Existe uma preocupação para que o planejamento na construção civil observe o que efetivamente pode ser realizado, com base na análise das restrições, na carga de trabalho e na capacidade produtiva disponível. Levando em consideração o estudo de caso e o referencial teórico analisados na pesquisa, mostra-se apropriado considerar as atividades vinculadas aos conceitos de restrições e capacidades como de interesse ao PCP. 


\section{CONCLUSÕES E CONSIDERAÇÕES FINAIS}

Deve-se ter em mente que as organizações estão em busca de sua dimensão ótima, através de movimentos de aproximação entre empresas, elas estão se moldando, se adaptando e como um dos resultados disso existe a formação de redes de empresas. A formação de redes de empresas deve ser observada como um dos resultados desta busca sendo de interesse prioritário quando se pretende manter autonomia jurídica e econômica.

O termo "rede de empresas" geralmente recorre a uma vasta gama de relações interorganizacionais, na qual as relações de cooperação interorganizacional do tipo "rede" diferem quanto a forma, rótulos ou fundos teóricos, porém de maneira geral remetem a conceitos semelhantes. Ainda é necessário um estudo mais aprofundado com o objetivo de propor uma taxonomia para adequar as diferentes redes entre empresas aos diferentes tipos de negócios, processos, produtos e ciclos de vida.

Com isso, neste trabalho se definiu o escopo da rede entre empresas de interesse e as características pertinentes. $\mathrm{O}$ escopo de atuação do trabalho refere-se a uma rede de empresas assimétrica (presença de uma hierarquia de poder, com um grupo de quatro empresas coordenando a rede como um todo) entre empresas autônomas, unidas com o objetivo de agregar competências de forma a atender uma oportunidade específica (produção do tipo MTO). A rede apresenta uma relação contratual formal, por meio de um contrato de consórcio entre empresas do setor da construção civil que caracteriza as relações interorganizacionais das empresas.

Uma vez admitido que a incerteza faz parte do cotidiano das atividades em um canteiro de obra, a atividade de planejamento deve se basear na utilização de toda a cultura organizacional e competência de parceiros na definição prévia dos parâmetros de desempenho esperados para o empreendimento. A função "planejamento" deve incorporar experiências passadas envolvidas nos processos ligados a empreendimentos e suas respectivas obras. Existe uma preocupação para que o planejamento na construção civil observe o que efetivamente pode ser realizado, com base na análise das restrições, na carga de trabalho e na capacidade produtiva disponível. 
Segundo o estudo de caso e o referencial teórico, analisados na pesquisa, mostrase apropriado apoiar o PCP na administração das capacidades, gestão de recursos e antecipações.

Como se pôde observar no Estudo de Caso - obra de implementação da Linha 4 do Sistema de Metrô de São Paulo, sustentando o conceito de sistema produtivo por projeto ou sistema de engenharia e produção sob encomenda, caracterizado pelo produto final ser de posição fixa, único, com ciclo de vida longo, projeto específico e inconstância de recursos em habilidades e quantidades - a importância da análise dos critérios de capacidades e restrições.

$\mathrm{Ou}$ seja, os Candidatos devem atender a todos os critérios mínimos que consideram a experiência geral e particular, experiências em construção civil, experiências em provisão e instalação de energia, fornecimento de sistemas para metrô, situação financeira, capacidades de pessoal e de equipamento, e outra informação pertinente requerida, com destaque para o Processo 1.1 - Criação/Configuração responsável pela elaboração, caracterização, determinação e licitação do objeto a ser produzido, determinando recursos e capacidades (Tabelas 07, 08, 09, 10, 11, 12, 13, 14, 15 e 16) a serem acatadas para o bom desenvolvimento do empreendimento. De modo a possibilitar um equilíbrio dinâmico, um equilíbrio entre a realidade de cada consorciado, bem como do próprio empreendimento conjunto.

Ao mesmo tempo, instrumentos jurídicos têm sido solicitados em acordo com a realidade econômica, como resposta à necessidade de lidar com um ambiente operacional em constante mudança. Apesar de uma obra de construção civil possuir elementos que permitam distingui-la como uma organização virtual é necessário regulamentar os mecanismos que forneçam dados de desempenho quantitativos e qualitativos e que reduzam as situações de incerteza, permitindo configurar negócios dentro de uma concepção de organização virtual eficaz.

As características morfológicas (nós, posições, ligações e fluxos) são conceitos que agem na tentativa de parametrizar a estrutura contingencial complexa de redes de empresas, cujos limites nem sempre são bem definidos, e mecanismos difusos. O ciclo de vida da rede auxilia na modelagem e compreensão das relações interorganizacionais. Pelo processo de negócio Produzir materializam-se as políticas gerenciais, procedimentos operacionais e processos de manufatura, o que condiciona a observar as atividades de PCP referentes a informações e recursos pertinentes como elementos integrantes do processo de negócio ao longo do ciclo de vida da rede, manifestando o 
que os atores organizacionais fazem para alcançar os objetivos. Infere que a modelagem organizacional é obtida por meio da modelagem dos processos de negócio. Como síntese de tal raciocínio foi proposto o Modelo de Planejamento e Controle da Produção (Figura 17) para essa situação.

A proposta modelagem (apresentada nas Figuras 17 e 18) enquadra-se no argumento que, mediante um apropriado conjunto de documentos antecipa-se os resultados esperados dos trabalhos a serem realizados, auxiliando na antecipação de eventos e na programação de atividades, uma vez que possibilita uma melhor compreensão do empreendimento.

Esta simples documentação facilita a analise da evolução do empreendimento e das disparidades do contratualmente proposto em relação ao praticado, convergindo no conhecimento dos pontos de melhoria a serem abordados ao longo do processo Produzir. Um exemplo seria a necessidade de substituição de uma determinada empresa, o prévio conhecimento da disposição dos atores, suas posições, suas ligações e as regras as quais estão submetidos ao longo da execução do empreendimento facilita a analise das influências e conseqüências sobre os participantes individualmente e empreendimento conjunto, aprimorando a atuação do Metrô como órgão de físcalização e controle (Empregador).

Outra possibilidade, sob a óptica de empresas subcontratadas, é a de facilitar a compreensão do contexto em que estão inseridas suas distintas Posições-Ligações e seus respectivos Nós e Regras, facilita antecipações, favorecendo o planejamento de capacidades e recursos, vislumbrando possíveis parcerias e diminuindo sua submissão a outras empresas.

A modelagem facilitou a visualização do processo Produzir de forma fluída em relação ao ciclo de vida da rede adquirindo características temporal. O modelo em EKD se apresentou coerente com as exigências levantadas na bibliografia de modelagem organizacional, uma vez que representou uma base de conhecimento. Essa base de conhecimento permite modificações, como a introdução de novas regras no processo ou novos agentes de forma diligente e representa adequadamente a estrutura, as atividades, o processo, as informações, os recursos, o pessoal, o objetivo e as restrições.

A coerência de apresentar um Modelo base para referência inicial que integra os conceitos relevantes - ciclo de vida da rede, processo de negócio Produzir e elementos morfológicos, de forma ampla - está em direcionar o raciocínio para auxiliar o desenvolvimento e análise de modelagens, explicando a causalidade e apresentando as 
ligações entre os objetos de estudo. Considera-se esta abordagem teórica como a principal contribuição acadêmica abalizada por esta pesquisa.

Entende-se que o objetivo do trabalho foi alcançado, visto que os conceitos de planejamento e controle da produção no ambiente de redes de empresas assimétricas a partir da visão da rede e do empreendimento segundo o ponto de vista do Empregador/Cliente (Metrô) foram representados em um modelo.

Um ponto importante a destacar é o fato de não ter sido possível à análise do ciclo de vida da rede por completo, em virtude do período de tempo necessário à concretização do empreendimento ser mais longo que o período de tempo disponível a realização da pesquisa. Desta forma a pesquisa ateve-se às fases do ciclo de vida Criação/Configuração e início da Operacionalização.

Deve-se ter em mente que o EKD não é uma ferramenta de software e nem uma abordagem que conduzirá a um software. O EKD não é a única metodologia aplicável ao contexto deste trabalho de pesquisa, porém a sua viabilidade ao contexto da pesquisa se apresentou valorosa, em virtude do pesquisador deter prévio domínio da metodologia, da flexibilidade de aplicação, da independência de plataformas tecnológicas (podendo ser elaborado com a utilização de lápis e papel), e apresentação gráfica de fácil compreensão, pontos estes que demonstraram seu valor durante a elaboração do Estudo de Caso, estudo este realizado nos mais distintos locais (canteiros de obra, escritórios, salas de reunião, estação de metrô e etc.) e com as mais distintas pessoas.

O EKD oferece uma estrutura de modelagem ampla, que permite diversas perspectivas de modelagem, uma vez que, examinar segundo uma única perspectiva de modelagem (produto, atividade ou papel) não é suficiente para expressar os processos de negócio.

Neste sentido, os Modelos apresentados (Figuras 12, 17 e 18) devem ser encarados como um ponto de partida, já que podem ser enriquecidos e aprofundados com outros modelos (regras, objetivo, sistema de informação, etc) e detalhamento, contribuindo para melhor visualização e compreensão da situação abordada.

Como propostas para futuros trabalhos estão:

- Desenvolver uma análise completa do ciclo de vida de uma rede de empresas assimétrica, aprofundando o proposto Modelo de Planejamento de Controle da Produção. 
- Levantamento de sistemas computacionais que suportem o Modelo apresentado, principalmente no referente ao fluxo de informações.

- Analisar os conceitos abordados e o proposto Modelo diante de distintas redes de empresas produtivas. 


\section{REFERÊNCIA BIBLIOGRAFICA}

ALENCAR, F. M. R. (1999). Mapeando a modelagem organizacional em especificações precisas. Tese (Doutorado) - Centro de Informática, Universidade Federal de Pernambuco, Recife.

ALVES. (1991). Revisão da literatura em teses e dissertações: meus tipos inesquecíveis. Digitado. Rio de Janeiro, Faculdade de Educação - UFRJ.

AMATO NETO, J. (2000). Redes de cooperação produtiva e clusters regionais: oportunidades para as pequenas e médias empresas. São Paulo: Atlas, Fundação Vanzolini.

APQC (2002). Process classification framework. Disponível em: $<$ http://www. apqc.org>. Acesso em: 02 set. 2002.

BARBOSA, F.A.; SACOMANO, J. B. (2001). As redes de negócios e as cadeias de suprimentos: um estudo de caso para compreensão conceitual. Anais XXI Encontro Nacional de Engenharia de Produção. Salvador-BA.

BELHOT, R. V. (1992). Sistema de produção e administração de capacidade. São Carlos: EESC-USP. Relatório Técnico.

BERLUSSI, F.;ARCANGELI, F. (1998). Typology of networks: flexible and evolutionary firms. Research Policy, n.27, p.415-428.

BREMER, C. F. (1996). Uma análise da aplicação do modelo de empresas virtuais na indústria brasileira. Anais do Encontro Nacional de Engenharia de Produção, UNIMEP/ABEPRO, 16 Piracicaba, CD-ROM.

BREMER, C. F.; CORREA, G. (1997). Experiências práticas em organizações e empresas virtuais. In: BRAZIL THIRD CONGRESS OF INDUSTRIAL ENGINNERING, 1997, Anais do XVII Encontro Nacional de Engenharia de Produção, Universidade Federal de Santa Catarina, out, CD-ROM.

BREMER, C. F.; LENZA, R. P. (2000). Um modelo de referência para gestão da produção em sistemas de produção assembly to order - ATO e suas múltiplas aplicações. Gestão \& Produção, v.7, n.3, p.269-282, dez.

BREMER, C. F.; ORTEGA, L. M. (2000). Redes de cooperação, Revista cientifica: Produtos \& Serviços, São Paulo, n.312, p.35-42, dez.

BRITTO, J. (2002). Cooperação interindustrial e redes de empresas. In: KUPFER, D.; HASENCLEVER, L., org's. Economia Industrial: fundamentos teóricos e práticos no Brasil. Rio de Janeiro: Campus. 
BUBENKO Jr., J. A.; STIRNA, J.; BRASH, D. (2001). EKD user guide, Dep. of computer and systems sciences. Stockholm, Royal Institute of Technology, Disponível em:<

http://www.verbundplan.at/HyperKnowledge/pdf/D3_appb final_version_2001_10 31 . pdf $>$ Acesso em 1 jul. 2003.

BURBIDGE, J. L. (1981). Planejamento e controle da produção. São Paulo: Atlas.

CAMARINHA-MATOS, L. M.; AFSARMANESH, H. (1999a). The virtual enterprise concept. Working Conference on Infrastructure for Virtual Enterprise (PROEV'99), 27-28 out., Porto, Portugal, p. 3-14.

CAMARINHA-MATOS, L. M.; AFSARMANESH, H. (1999b). Tendencies and general requirements for virtual enterprises. Working Conference on Infrastructure for Virtual Enterprise (PRO-EV'99), 27-28 out., Porto, Portugal, p. 15-30.

CAMARINHA-MATOS, L. M.; LIMA, C. P. (1999). Coordination and configuration requirements in a virtual enterprise. Working Conference on Infrastructure for Virtual Enterprise (PRO-EV'99), 27-28 out., Porto, Portugal, p. 49-64.

CARPINETTI, L. C. R. (2000). Uma proposta para o processo de identificação e desdobramento de melhorias da manufatura: uma abordagem estratégica. Tese (Livre-Docência) - Escola de Engenharia de São Carlos, Universidade de São Paulo, São Carlos.

CASAROTTO, R. M. (2002) Redes de empresas na indústria da construção civil: definição de funções e atividades de cooperação. Tese (Doutorado) - Programa de PósGraduação em Engenharia de Produção, Universidade Federal de Santa Catarina, Florianópolis.

CASTELlS, M. (1999). A sociedade em rede, São Paulo: Paz e Terra.

CHAMBERS, D. B.; BÁGUENA, F. S.; FERNÁNDEZ, M. G. (2000). Production planning and control information system for the engineering and make to order environment: a virtual enterprise approach. Working Conference on Infrastructure for Virtual Enterprise (PRO-EV'00), 4-6 dec., Florianópolis, Brazil, p. 333-340.

CHECKLAND, P. B. (1981). Systems thinking, systems practice. New York: Jonh Wiley \& Sons.

CO-IM. (2003). Cooperative Information Management. Disponível em: $<$ http://carol.wins.uva.nl/ netpeer/>. Acesso em: 02 jul. 2003.

CONTADOR, J. C.; CONTADOR J. L. (1997). Programação e controle da produção para indústrias intermitentes. In: CONTADOR, J. C., coord. Gestão de operações: a engenharia de produção a serviço da modernização da empresa. São Paulo: Edgard Blucher/Fundação Vanzolini.

CONTE, A. S. I. (1997). Lean construction - o caminho para a excelência operacional na construção civil. In: CONTADOR, J. C., coord. Gestão de operações: a engenharia de produção a serviço da modernização da empresa. São Paulo: Edgard Blucher/Fundação Vanzolini. 
CORRÊA, G. N. (1999). Proposta de otimização da integração de parceiros na formação e gerência de empresas virtuais. Tese (Doutorado) - Escola de Engenharia de São Carlos, Universidade de São Paulo, São Carlos.

COVE. (2003). Cooperation Infrastructure for virtual enterprises. Disponível em: $<$ http://www.uninova.pt/ cove/coveproject.htm>. Acesso em: 02 jul.2003.

DAVENPORT, T. H. (1994). Reengenharia de processos: como inovar na empresa através da tecnologia da informação. Rio de Janeiro: Campus.

De TONI, A.; MENEGHETTI, A. (2000). The production planning process for a network of firms in the textile-apparel industry. International Journal of Production Economics. n.65, p.17-32.

DESS, G. G. et al. (1995). The new corporate architeture. Academy of Management Executive, v.9, n.3, p.7-20.

FARIA, A. (2000). Cooperação em redes verticais entre empresas de portes distintos: em busca de um modelo realista. Anais do I EGEPE, p. 408-421, out.(ISSN 1518-4382).

ESPRIT. (2003). European Strategic Programme for Research \& development in Information Technologies. Disponível em: <http:/www.cordis.lu/esprit/home.html $>$. Acesso em: 02 jul. 2003.

GARVIN, D. A.(1995). Leveraging processes for strategic advantage. Harvard Business Review, p.77-90, Sep/Oct.

GEBREKIDAN, D. A.; AWUAH, G. B. (2002). Interorganizational cooperation: a new view of strategic alliances: The case of Swedish firms in the international market. Industrial Marketing Management, n.31, p.679-693.

GONÇALVES, J.E.L. (1997). Os novos desafios da empresa do futuro. Revista de Administração de Empresas, São Paulo, v.37, n.3, p.10-19, jul/set.

GONÇALVES, J.E.L. (2000a). As empresas são grandes coleções de processos. Revista de Administração de Empresas, São Paulo, v.40, n.1, p.6-19, jan/mar.

GONÇALVES, J.E.L. (2000b). Processos que processos. Revista de Administração de Empresas, São Paulo, v.40, n.4, p.8-19, out/dez.

GORANSON, H. T. (1999).The agile virtual enterprise: cases, metrics, tools. Quorum Books.

GOULART, C. P. (2000). Proposta de um modelo de referencia para planejamento e controle da produção em empresas virtuais. Dissertação (Mestrado) - Escola de Engenharia de São Carlos, Universidade de São Paulo, São Carlos.

GRAHAM, M.; LeBARON, M. (1994). The horizontal revolution. San Francisco: Jossey-Bass.

GRANDORI, A.; SODA, G. (1995). Inter-firm network: antecedents, mechanisms and forms. Organization Studies. 16/2, p.183-214. 
HAMMER, M.; CHAMPY, J. (1994). Reengenharia: revolucionando a empresa em função dos clientes, da concorrência e das grandes mudanças da gerência. Rio de Janeiro: Campus.

KAVAKLI, V.; LOUCOPOULOS, P. (1999). Goal-driven business process analysis application in electricity deregulation. Information Systems, v.24, n.3, p.187-207.

KEHL, S. P. (1997). Produtividade na construção civil. In: CONTADOR, J. C., coord. Gestão de operações: a engenharia de produção a serviço da modernização da empresa. São Paulo: Edgard Blucher/Fundação Vanzolini.

KEHOE, D.; BOUGHTON, N. (2001). Internet based supply chain management: A classification of approaches to manufacturing planning and control. International Journal of Operations \& Production Management, v.21, n.4, p. 516-524.

LAKATOS, E. M.; MARCONI, M. (1991). Metodologia científica. São Paulo: Atlas.

LEÃO, L. C. G. (2000). Uma contribuição ao planejamento de consórcio de empresas. Dissertação (Mestrado) - Faculdade de Economia, Administração e Contabilidade, Universidade de São Paulo, São Paulo.

LEE, W.B.; LAU, H.C.W. (1999). Factory on demand: the shaping of an agile production network. International Journal of Agile Management Systems 1/2 p.8387.

LEVIN, B. M. (1998). Strategic networks: The emerging business organization and its impact on production costs. International Journal of Production Economics, v.56-57, p. 397-405.

LOUCOPOULOS, P.; KAVAKLI, V.; PREKAS, N. ROLLAND, C.; GROSZ, G.; NURCAN, S. (1997). Using the EKD approach: the modeling component, ELEKTRA Research Report, April.

LOUCOPOULOS, P.; KAVAKLI, V. (1999). Goal-driven business process analysis application in electricity deregulation. Information Systems. v.24, n.3, p.187-207.

LOUSÃ, M.; SARCAMENTO, A.; ALTAMIRO, M. (2003). Sistema de automatização de processos de negócios (workflow systems): considerações sobre o contexto organizacional e proposta de estrutura de análise do seu impacto nas organizações. Disponível em:< http://www.di.fc.ul.pt/ paa/coopmedia/coopmedia2000/lousa.pdf $>$ Acesso em 13 jan. 2003.

MACHADO, R. L. (2003) Sistematização de antecipações gerenciais no planejamento da produção de sistemas da construção civil. Tese (Doutorado) Programa de Pós-Graduação em Engenharia de Produção, Universidade Federal de Santa Catarina, Florianópolis.

MANCUSO, F. L.; EDELWEISS, N. (2002). Modelagem de empresas: integração de diferentes métodos através do formalismo TF-ORM, Disponível em:< http://www.read.adm.ufrgs.br/read11/artigo/artigo2.htm> Acesso em: 13 dez. 2002. 
MARTIN, J. (1996). Cybercorp: the new business revolution. New York: Amacom.

MARTINS, R. A. (1993).Flexibilidade e integração no novo paradigma produtivo mundial. Dissertação (Mestrado) - Escola de Engenharia de São Carlos, Universidade de São Paulo, São Carlos.

MELHADO, S. B. (2001). Gestão, cooperação e integração para um novo modelo voltado à qualidade do processo de projeto na construção de edifícios. Tese (Livre Docência) - Escola Politécnica, Universidade de São Paulo, São Paulo.

MEZGÁR, I.; KOVÁCS, G. L.; PAGANELLI. P. (2000). Co-operative production planning for small-and medium-sized enterprises. International Journal of Production Economics. n.64, p.37-48.

MINTZBERG, H. (1979). The structure of organizations. Englewood Cliffs: Prentice Hall.

MINTZBERG, H. (1995). Criando organizações eficazes: estruturas em cinco configurações. São Paulo: Atlas.

MIZRUCHI, M.S. \& GALASKIEWICZ, J. (1993). Networks of Interorganizational Relations. Sociological Methods \& Research. v. 22, n. 11, p. 46-70.

MORRIS, D.; BRANDON, J. (1994). Reengenharia: reestruturando sua empresa. São Paulo: Makron Books.

MOTTA, F. C. P. (1986). Teoria das organizações: evolução e critica. São Paulo: Pioneira.

NAOUM, S. G. (2000). Dissertation research and writing for construction students. Rochesters: Butterrworth Heinemann.

NASSIMBENI, G. (1998). Network structures and co-ordination mechanisms: a taxonomy. International Journal of Operations \& Production Management, v.18, n.6, p. 538-554.

NEVES, M.F. (2002). Um modelo para construir ou revisar contratos em redes de empresas. Revista de Economia e Administração, São Paulo, v.1, n.2, p.68-86.

NEW, S.; MITROPOULOS, I. (1995). Strategic network: morphology, epistemology and praxis. Interantional Journal of Production Management, v. 15, n. 11, p. 53-61.

OHNUMA, D. K. (2003). Modelo de processos para gestão de subempreiteiros: estudo de caso em empresas construtoras de edifícios. Dissertação (Mestrado) - Escola Politécnica, Universidade de São Paulo, São Paulo.

OLAVE, M. E. L.; AMATO, J. (2001). Redes de cooperação produtiva: estratégia de competitividade e sobrevivência para pequenas e médias empresas. Gestão \& Produção, v.8, n.3, p.289-303, dez. 
OLIVEIRA, T. A. M. (2000). Proposta de uma infra-estrutura jurídica para organizações e empresas virtuais. Dissertação (Mestrado) - Escola de Engenharia de São Carlos, Universidade de São Paulo, São Carlos.

PÁDUA, S. I. D. (2001). Investigação do processo de desenvolvimento de software a partir da modelagem organizacional, enfatizando regras do negócio. Dissertação (Mestrado) - Escola de Engenharia de São Carlos, Universidade de São Paulo, São Carlos.

PENTEADO, M. R. (1990). Contrato de consorcio. In: BITTAR, C. A., coord. Novos Contratos Empresariais. São Paulo: Ed Revista dos Tribunais.

PIDD, M. (1997). Modelagem empresarial: ferramentas para a tomada de decisão. São Paulo: Bookman Companhia Editora.

PINE II, B. J. (1994). Personalizando produtos e serviços: customização em massa. São Paulo: Makron Books.

PIRES, S.R.I. (1994). Integração do planejamento e controle da produção a uma estratégia da manufatura. Tese (Doutorado) - Escola de Engenharia de São Carlos, Universidade de São Paulo, São Carlos.

PIRES, S. R. I. (1995). Gestão estratégica da produção. Piracicaba: Editora Unimep.

PIRES, S. R. I. (2001). Gestão da cadeia de suprimentos e suas implicações no planejamento e controle da produção. In: AMATO NETO, J., Org. Manufatura classe mundial: conceitos, estratégias e aplicações. São Paulo: Atlas.

PIRES, S. R. I.; MUSETTI, M. A. (2000). Logística integrada e gestão da cadeia de suprimentos, Revista cientifica: Produtos \& Serviços, São Paulo, n.312, p.65-76, dez.

PIRES, S. R. I.; BREMER, C. F.; EULÁliA, L. A. S.; GOULART, C. P. (2001). Supply Chain and virtual enterprise: migration and a case study. International Journal of Logistics: research and applications, London, v. 4, n. 3, p. 197-311.

PORTER, M, E. (1992). Vantagem competitiva: Criando e sustentando um desempenho superior, Rio de Janeiro: Campus.

REDECOOP. (2003). Rede de Cooperação e Gestão do Conhecimento Technologies. Disponível em: <http://www.prd.usp.br/redecoop/>. Acesso em: 02 jul.2003

RENTES, A. F. (1995). Proposta de uma metodologia de integração com utilização de conceitos de modelagem de empresas. Tese (Doutorado) - Escola de Engelharia de São Carlos, Universidade de São Paulo, São Carlos.

RENTES, A. F.; CAMPEÃO, P.; FIORELli, A. O.; NOBRE, M; ROLIM, L. V. (1995). Uma abordagem de reengenharia de processos integrada a uma metodologia de integração da manufatura. Anais XV Congresso Nacional de Engenharia de Produção, São Carlos, p.1584-1588. 
ROLLAND, C.; NURCAN, S.; GROSZ, G. (2000). A decision making pattern for guiding the enterprise knowledge development process. Information and Software Technology, v.42, p.313-331.

ROSENFELD, S. A. (1996). Does cooperation enhance competitiveness? Assessing the impacts of -inter-firm collaboration. Research Policy, v.25, n.2, p. 247-263.

ROTONDARO, R. G. (1997). Gerenciamento por processos. In: CONTADOR, J. C., coord. Gestão de operações: a engenharia de produção a serviço da modernização da empresa. São Paulo: Edgard Blucher/Fundação Vanzolini.

ROZENFELD, H. (1996). Pra integrar a manufatura é importante o domínio dos business processes. Maquinas e Metais, São Paulo, v.31, n.369, p32-47, out.

SANTOS, M. T. S; MOCCELLIN, J. V. (2000). O planejamento da produção e a programação de obras de empresas construtoras em São Carlos e região. Lean Construction Institute do Brasil, São Paulo, p. 1-11.

SLACK, N. (1993). Vantagem competitiva em manufatura: atingindo competitividade nas operações industriais. São Paulo: Atlas.

SLACK, N.; CHAMBERS, S.; HARLAND, C.; HARRISON, A.; JOHNSTON, R. (1997). Administração da Produção. São Paulo: Atlas.

THIOLlENT, M. (1983). Problemas de metodologia. In: FLEURY, A.C.C. \& VARGAS, N. (orgs.). Organização do trabalho. 2ed. São Paulo: Atlas, p.54-83.

THIVES Jr, J. J. (2002). A tecnologia de workflow e a transformação do conhecimento In: ANGELONI, M. T., coord. Organizações do conhecimento: infra-estrutura, pessoas e tecnologias. São Paulo: Saraiva.

TSAKOPOULOS, S.; BOKMA, A. (2000). Process support for virtual projects in the construction sector. Working Conference on Infrastructure for Virtual Enterprise (PRO-EV'00), 4-6 dec., Florianópolis, Brazil, p. 351-358.

VASCONCELOS, P. A. S. (1999). O contrato de consórcio: no âmbito dos contratos de cooperação entre empresas. Boletim da Faculdade de Direito - Universidade de Coimbra, Coimbra: Coimbra Editora.

VERNADAT, F. B. (1996). Enterprise Modeling and Integration: principles and applications. New York: Chapman \& Hall, London.

VILKANO, T. \& KEIL, T. (2003). Strategic technology partnering in high-velocity environments-lessons from a case study. Technovation, n. 23, p. 193-204.

VIVE. (2003). Virtual Vertical Enterprises. Disponível em: $<$ http://www.ceconsulting.it/VIVE/>. Acesso em: 02 jul.2003.

VOLLMANN, T.E.; BERRY, W.L.; WHYBARK, D.C. (1997). Manufacturing planning and control systems. 4.ed. New York: McGraw-Hill. 
WIENDAHL, H. P.; HARMS, T. (2000). The price-date-relationship as a negotiating tool in production planning and control. Working Conference on Infrastructure for Virtual Enterprise (PRO-EV’00), 4-6 dec., Florianópolis, Brazil, p. 327-332.

WIENDAHL, H. P.; HÖBIG, M. (1998). Balanced production planning and control in production networks. Proceeding of the International Conference of Manufacturing Value-Chain, Troon, Scotland, UK.

WILLIAMS, T. (2002). Cooperation by design: structure and cooperation in interorganizational networks Journal of Business Research, 5867, p.1-9, Acessível on line 21 nov. 2002.

WOOD Jr, T.; ZUFFO, P. K. (1998). Supply chain management. Revista de Administração de Empresas, São Paulo, v.38, n.3, p.55-63, jul/set.

YIN, R. K. (2001). Estudo de Caso: planejamento métodos. São Paulo: Bookman Companhia Editorial.

ZACCARELLI, Z. B. (1979). Programação e controle da produção. 5.ed. São Paulo: Pioneira. 


\section{ANEXO A}

Programa de Execução do Lote 1 da Linha 4 - Amarela,

Alínea d - Cláusula 3.1 do Instrumento Contratual 